\title{
Regional Flow in the Dakota Aquifer: A Study of the Role of Confining Layers
}

United States Geological Survey Water-Supply Paper 2237

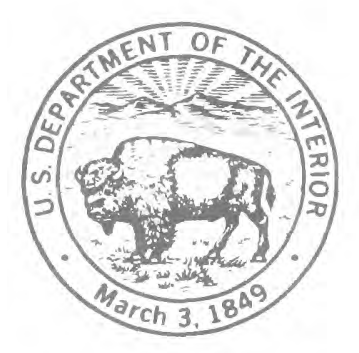




\section{Regional Flow in the Dakota Aquifer: A Study of the Role of Confining Layers}

By J. D. Bredehoeft, C. E. Neuzil, and

P. C. D. Milly

U.S. GEOLOGICAL SURVEY WATER-SUPPLY PAPER 2237 


\section{UNITED STATES DEPARTMENT OF THE INTERIOR JAMES G. WATT, Secretary

\author{
GEOLOGICAL SURVEY \\ Dallas L. Peck, Director
}

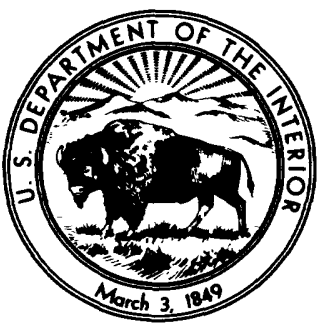

For sale by Distribution Branch

Text Products Section

U.S. Geological Survey

604 South Pickett Street

Alexandria, Virginia 22304

\section{Library of Congress Cataloging in Publication Data}

Bredehoeft, J. D. (John D.)

Regional flow in the Dakota aquifer.

(Geological Survey water-supply paper ; 2237)

Bibliography: $p$.

Supt. of Docs. no.: I 19.13:2237

1. Groundwater flow-Great Plains. 2. Dakota Aquifer. I.

Neuzil, C. E. II. Milly, P. C. D. III. Title. IV. Series.

$\begin{array}{llll}\text { GB1197.7.B73 } & 1983 \quad 553.7^{\prime} 9^{\prime} 09783 & \text { 83-600246 }\end{array}$ 


\section{CONTENTS}

Abstract 1

Introduction 1

Geology of the ground-water system 3

Hydraulic conductivity of the Dakota aquifer 8

Simulation of region flow 11

Model analysis 13

Model of Cretaceous shale confining layer 17

Simulation parameters 20

Total flow 21

Cretaceous shale confining layer: In situ and laboratory tests 21

Pumping test at Wall, South Dakota 21

Slug tests in the Pierre Shale 25

Laboratory pulse tests 25

Laboratory consolidation tests 27

Discussion of shale hydraulic properties 28

Hydraulic conductivity 28

Specific storage 29

Transport of sulfate in the ground water 30

Distribution of sulfate 31

Simulation of sulfate transport 31

Sulfate transport in the Inyan Kara Group sandstones 34

Sulfate transport in the Dakota-Newcastle Sandstone 34

The role of geological membranes in the transport of sulfate 38

Chloride in the ground water 42

Discussion 42

Simplifying assumptions 42

Conclusions 43

Acknowledgments 43

References 44

\section{FIGURES}

1. Aquifer system in South Dakota 4

2. Isolith map of the Inyan Kara Group sandstones 6

3. Isolith map of the Dakota-Newcastle Sandstone 7

4. Minor aquifer system above the Dakota Sandstone in South Dakota 10

5. Graph showing specific capacity versus transmissivity for a flowing well 11

6. Maps showing distribution of most reliable well hydraulic conductivity data and third-degree polynomial trend surfaces computed from subsets of the data 12

7. Diagrammatic cross section showing the simplest conceptual model used to analyze the Dakota aquifer 13

8. Sketch depicting the arrangement of finite-difference grids used for the three-aquifer model of the Dakota system 14

9. Map showing virgin potentiometric surface, relative to land surface, for the Dakota aquifer 15

10. Map showing computed virgin potentiometric surface, relative to land surface, for the Dakota aquifer (assumed hydraulic conductivity for the combined Cretaceous shale confining layer of $5 \times 10^{-9} \mathrm{ft} / \mathrm{sec}$ ) 16

11. Map showing computed virgin potentiometric surface, relative to land surface, for the Dakota aquifer (assumed hydraulic conductivity for the combined Cretaceous shale confining layer of $\left.5 \times 10^{-11} \mathrm{ft} / \mathrm{sec}\right) 17$ 
12. Maps showing virgin potentiometric surface, relative to sea level, for the Dakota aquifer 18

13. Graph showing well discharge and number of wells in the Dakota aquifer 21

14. Maps showing potentiometric surface in the Dakota aquifer in 191522

15. Map showing computed potentiometric surface in the Dakota aquifer for 190824

16. Sketch showing computed virgin, or steady flow, through the aquifer system in South Dakota 25

17. Map showing computed steady-state leakage through Cretaceous shale confining layer 26

18. Plot of drawdown data from pumping test at Wall, South Dakota 27

19. Map showing locations of test hole sites 27

20. Schematic diagram of slug test setup 27

21. Plot of pressure-decay data for a modified slug test in the Pierre Shale 28

22. Section showing hydraulic conductivity of the Pierre Shale calculated from modified slug tests 28

23. Summary plot of hydraulic conductivity data for the Cretaceous shale confining layer 30

24. Summary plot of specific storage data for the Cretaceous shale confining layer 31

25. Map showing sulfate concentrations in Dakota-Newcastle ground water 32

26. Map showing sulfate concentrations in Inyan Kara ground water 33

27. Map showing areal distribution of gypsum and anhydrite $\mathbf{3 5}$

28. Map showing calculated sulfate concentrations for Inyan Kara ground water $\mathbf{3 6}$

29. Map showing calculated sulfate concentrations for the Dakota-Newcastle ground water 37

30. Graph of net filtration ratio, $F$, as a function of shale thickness, b 39

31. Map showing calculated sulfate concentrations for the Dakota-Newcastle ground water 40

32. Map showing chloride concentrations in Dakota-Newcastle ground water 41

\section{TABLES}

1. Summary of hydraulic conductivity estimates for the Dakota Sandstone 9

2. Summary of Niven's (1967) outcrop data 9

3. "Best-fit" parameters used in various model analyses 20

4. Summary of pulse test results for the Pierre Shale 29

5. Summary of consolidation test results for the Pierre Shale 29 


\title{
REGIONAL FLOW IN THE DAKOTA AQUIFER: A STUDY OF THE ROLE OF CONFINING LAYERS
}

\author{
By J. D. Bredehoeft, C. E. Neuzil, and P. C. D. Milly
}

\begin{abstract}
The Dakota Sandstone in South Dakota is one of the classic artesian aquifers; it was first studied by N. H. Darton at the turn of the century. Since then, hydrogeologists have debated the source of the large quantities of water which have been discharged by artesian flow from the Dakota. Among suggestions for the source of this water are (1) recharge of the aquifer at outcrops in the Black Hills, (2) compaction and compressive storage within the aquifer, (3) leakage through confining layers, and (4) upward flow from the underlying Madison Group limestones.

A series of increasingly refined models of the aquifer system in South Dakota have been developed and used for numerical simulations of the ground-water flow. The simulations have provided estimates of leakage through the confining layers. The results indicate that, before development, most of the flow into and out of the Dakota Sandstone occurred as leakage through confining layers and, since development, most of the water released from storage has come from the confining layers.

In situ and laboratory hydraulic conductivity measurements have been made for the Cretaceous shale confining layer which overlies the Dakota. These data indicate hydraulic conductivities which are one to three orders of magnitude lower than the conductivities indicated by the numerical analyses; this suggests that the leakage through the confining layer is largely through fractures. The fractures apparently did not influence the laboratory and in situ measurements.

To test the conception of flow in the aquifer-confining layer system derived from our analyses, the transport of sulfate in the system was simulated. Simulations using a numerical ground-water transport model were reasonably successful in explaining the present distribution of sulfate in the system. This result increases confidence in the flow system implied by the flow simulations in which leakage through confining layers is dominant.
\end{abstract}

\section{INTRODUCTION}

The Dakota aquifer in South Dakota is one of the classic artesian aquifers. Many modern ideas concerning artesian aquifers stem from N. H. Darton's investi- gation of the Dakota aquifer in the 1890's and early 1900 's. This paper is based to a large extent upon Darton's data and is a tribute to Darton's ability as a hydrologist.

It is clear from examining Darton's work that he understood most aspects of the ground-water hydrology of the Dakota aquifer. In 1896, he published a preliminary report which described the system (Darton, 1896). $\mathrm{He}$ and workers under his direction then proceeded systematically to map the area of principal ground-water development along the James River in eastern South Dakota; much of the actual mapping was done by J. E. Todd under Darton's direction. A series of Geologic Folios were published which covered the ground-water geology of the James River lowland from Nebraska to North Dakota. These folios, designed to display the ground-water geology of the area, are classic examples of hydrogeologic mapping.

While Todd mapped the area of major development, Darton mapped the entire Black Hills in four quadrangles. The Black Hills area included the Dakota outcrop, a source of recharge for the Dakota aquifer in South Dakota. Darton (1909) summarized his Dakota investigations in U.S. Geological Survey Water-Supply Paper 227. He pointed out that the potentiometric head within the Dakota system is controlled by the elevation of the sandstone outcrops in the Black Hills and set forth his ideas concerning the mechanics of the system in the following remarks (Darton, 1909, p. 60):

"The evidence of this pressure, as found in many wells in eastern South Dakota, is conclusive that the water flows underground for many hundreds of miles. Such pressures can be explained only by the hydrostatic influence of a column of water extending to a high altitude on the west. If it were not for the outflow of the water to the east and south the initial head which the waters derived from the high lands of the intake zone would continue under the entire region, but owing to this leakage the head is not maintained, and there is a gradual diminution toward the east known as 'hydraulic grade,' a slope sustained by the friction of the water in its passage through the strata." 
Darton fully understood that some water must flow through the overlying confining layers; he goes on to state $(1909$, p. 60$)$ :

\footnotetext{
"Another factor which undoubtedly somewhat influences the hydraulic grade in the Great Plains region is a certain but unknown amount of general leakage through the so-called impermeable strata, especially when under great pressure."
}

Darton's conception of the Dakota system follows rather closely T. C. Chamberlin's earlier ideas. Chamberlin (1885) published a paper entitled Requisite and Qualifying Conditions of Artesian Wells. His discussion of "confining beds" is particularly appropriate:

\footnotetext{
"No stratum is entirely impervious. It is scarcely too strong to assert that no rock is absolutely impenetrable to water. Minute pores are well-nigh all pervading. To these are added microscopic seams, and to these again larger cracks and crevices. Consolidated strata are almost universally fissured. Even clay beds are not entirely free from partings.

"But in the study of artesian wells we are not dealing with absolutes but with availables. A stratum that successfully restrains the most of the water, and thus aids in yielding a flow, is serviceably impervious. It may be penetrated by considerable quantities of water, so that the leakage is quite appreciable and yet be an available confining stratum."
}

Many of our modern ideas of the hydrology of artesian aquifers originated in these investigations by Chamberlin and Darton and his colleagues. Many elementary geology texts use Darton's illustrations of the Dakota to introduce artesian aquifers. Darton's ideas of the mechanics of the Dakota system, especially of the leakage through the confining layer, were explicit. These ideas seem to have become lost in the intervening years.

Russell (1928), following extensive stratigraphic study of the Dakota in the outcrop area in eastern South Dakota, questioned Darton's explanation of the artesian pressures. Russell pointed out that the sandstones which comprise the aquifer differ in age from the outcrops in the Black Hills. He also pointed out the distinct variations in the chemistry of the Dakota water. Based upon this evidence, Russell suggested that the sandstones were lenticular and that the artesian pressure was the result of a reduction in pore volume within the sandstone due to sedimentary loading.

Russell's paper excited considerable discussion. Terzaghi (1929) examined Russell's mechanism in the light of the theory of consolidation and pointed out that Russell's suggested mechanism was most improbable. Piper (1928) questioned Russell's stratigraphy, suggesting again that the aquifer sandstones were probably continuous.
At the time of Russell's paper, Meinzer (1928) had a paper in press which suggested that the artesian head supports a portion of the load of the overlying rocks and that aquifers undergo small changes in pore volume as the head changes. He further stated that some part of the water discharged from the Dakota was derived from this elastic change in pore volume. This was the first lucid statement of storage in an artesian system.

It is clear from correspondence that Meinzer's ideas were based to a large extent upon discussions with D. G. Thompson, who was working in New Jersey. Thompson (1929) discussed both Meinzer's (1928) and Russell's (1928) papers and reiterated the importance of storage within the aquifer system.

Some time later, J. P. Gries (1958), who contributed greatly to the present understanding of Dakota stratigraphy, discussed the problem. It was clear by then that the discontinuous Newcastle Sandstone was the western equivalent of the Dakota Sandstone. Gries analyzed this complication of the artesian system Darton had envisioned with particular insight:

"But since the Dakota does not crop out around the Hills, except for the thin, fine sandstones which make up the Newcastle...the source of the artesian water must be less direct than Darton thought. It is still likely that the Black Hills form the intake area, but if so, the water must enter the sandstones of the Inyan Kara Group, move eastward through them, then find its way up into the higher sandstones within the Dakota formation.

"Two possible routes are suggested. It may migrate eastward to where the Skull Creek shale disappears... or it may move upward through fractures in the Skull Creek shale."

More recently, Swenson (1968) again questioned the ability of the Dakota system to transmit the quantity of water known to have been produced in eastern South Dakota under the existing hydraulic gradients. $\mathrm{He}$, too, emphasized the differences in the chemistry of the Dakota water. He suggested that limestones of the Madison Group may be truncated by the lowermost sandstones of the Dakota aquifer in central South Dakota. He went on to suggest that the bulk of Dakota water in eastern South Dakota is recharged from these underlying Madison Group limestones. It is implicit in Swenson's (1968) remarks that he thought the system was very nearly in steady state with little or no water still being derived from storage. The suggestion that the Dakota is recharged by water from the Madison Group limestones had been stated previously by Dyer and Goehring (1965) in a study of the Dakota aquifer in southeastern South Dakota.

The same question-can the Dakota aquifer alone provide the quantities of water known to have been produced from the system or must one look for an addi- 
tional source?-is implied in each of the discussions following Darton. This report describes our analysis, using numerical simulations, of the hydrodynamics and geochemistry of the Dakota aquifer and suggests answers to the question posed above. Recognizing that low-permeability confining layers and high-permeability aquifers are interacting parts of a single system, this investigation was directed toward understanding the aquifer system as a whole. The flow was first simulated using a very simplified model of the system, which consisted of a single aquifer, the Dakota, confined by one leaky confining layer, the Cretaceous shales. The original model was then refined by adding the Madison aquifer and confining layer and then by subdividing the Dakota into two aquifers in western South Dakota, the Inyan Kara and Newcastle, with the appropriate intervening confining layer.

Even though the Dakota aquifer has been studied for almost 90 years, relatively little published data concerning its hydraulic conductivity exists. Niven (1967) measured the hydraulic conductivity of approximately 300 samples taken from the outcrops of the Inyan Kara and Newscastle sandstones in the Black Hills. A test was run on a well at Box Elder, South Dakota, near the outcrop area of the sands on the east flank of the Black Hills (Miller and Rahn, 1974), and another was conducted at Wall, South Dakota (Gries and others, 1976). These data comprise the published hydraulic conductivity information for the Dakota aquifer in South Dakota.

During the course of this study, Martin Sather, a water-well drilling contractor in Presho, South Dakota, made available the records of the Norbeck and Hollis Drilling Company. This firm was perhaps the largest drilling company in South Dakota in the early 1900's, operating some 27 rigs at one time. Only the drilling reports are available; however, it is possible to estimate the hydraulic conductivity of the aquifer through careful use of these data. This was done for approximately 500 wells drilled in the years 1904 through 1908.

Darton (1909) published a regional potentiometric surface for the Dakota aquifer using the earliest available drilling reports. By the time his report was published, more than 1,000 wells had penetrated the Dakota, most of which flowed. Rothrock had Robinson (1936), Erickson (1954, 1955), Barkley (1953), and Schoon (1971) document the historic change in the potentiometric surface, and Davis and others (1961) describe its effect on wells in South Dakota. Because of the aquifer's importance to South Dakota's water supply, relatively complete records of rates and locations of water withdrawal from the Dakota Sandstone were made, beginning shortly after the start of development. These records are available in the biennial and annual reports of the South Dakota State Engineer. Together, these data document the withdrawal of water from the aquifer and the resulting change in the potentiometric surface.

\section{GEOLOGY OF THE GROUND-WATER SYSTEM}

Present day South Dakota was a site of sedimentary deposition from Paleozoic to Tertiary time. Except for Tertiary deposits which have largely been removed by erosion, most of the sedimentary formations are still present in the western part of the State. In the eastern part of South Dakota, much of the younger sedimentary cover has been removed. Structurally, there is a northsouth-trending shallow trough with its axis west of the center of the State. Two structural highs exist: the Sioux Ridge, a gentle high of Precambrian quartzite, near the eastern edge of the State and the Black Hills, a dome of crystalline Precambrian rocks with younger sedimentary strata dipping outward on its flanks, along the western edge of the State.

Elevations are highest in the Black Hills area and diminish more or less uniformly to the east. This trend is broken by the deeply eroded valley of the Missouri River, the so-called Missouri Trench. Outcrops of the major aquifers are generally at an altitude of 3,000 to 4,000 ft around the Black Hills. Outcrops of the Dakota Sandstone in the eastern part of the State are at an altitude of approximately $1,000 \mathrm{ft}$. In roughly the western half of the State, west of the Missouri River, the terrain is quite old, with several rivers which flow approximately from west to east draining to the Missouri. Pleistocene till dissected by a postglacial drainage system blankets most of the area east of the Missouri River.

The ground-water system is dominated by three major aquifers (Darton, 1909; Gries, 1958; Swenson, 1968; Schoon, 1971). The areas of aquifer outcrop are shown in figure $1 A$, and a schematic cross section of the aquifers and their confining layers is presented in figure $1 B$. The lowest aquifer, primarily Mississippian carbonate rocks collectively called the Madison Group, terminates in the subsurface beneath the Inyan Kara Group sandstones (Swenson, 1968; Schoon, 1971). The Inyan Kara Group and the Newcastle Sandstone, both distinct aquifers in the western portion of the State, merge to form the Dakota Sandstone in the eastern part of the State (Gries, 1958; Schoon, 1971). All three aquifers, the Madison, the Inyan Kara, and the DakotaNewcastle, crop out on the flanks of the Black Hills, although the Newcastle Sandstone may be discontinuous eastward (Gries, 1958; Schoon, 1971). The Dakota crops out in the extreme eastern part of South Dakota.

Although it remained for Gries $(1954,1958)$ and others to sort out the Dakota and Inyan Kara stratig- 


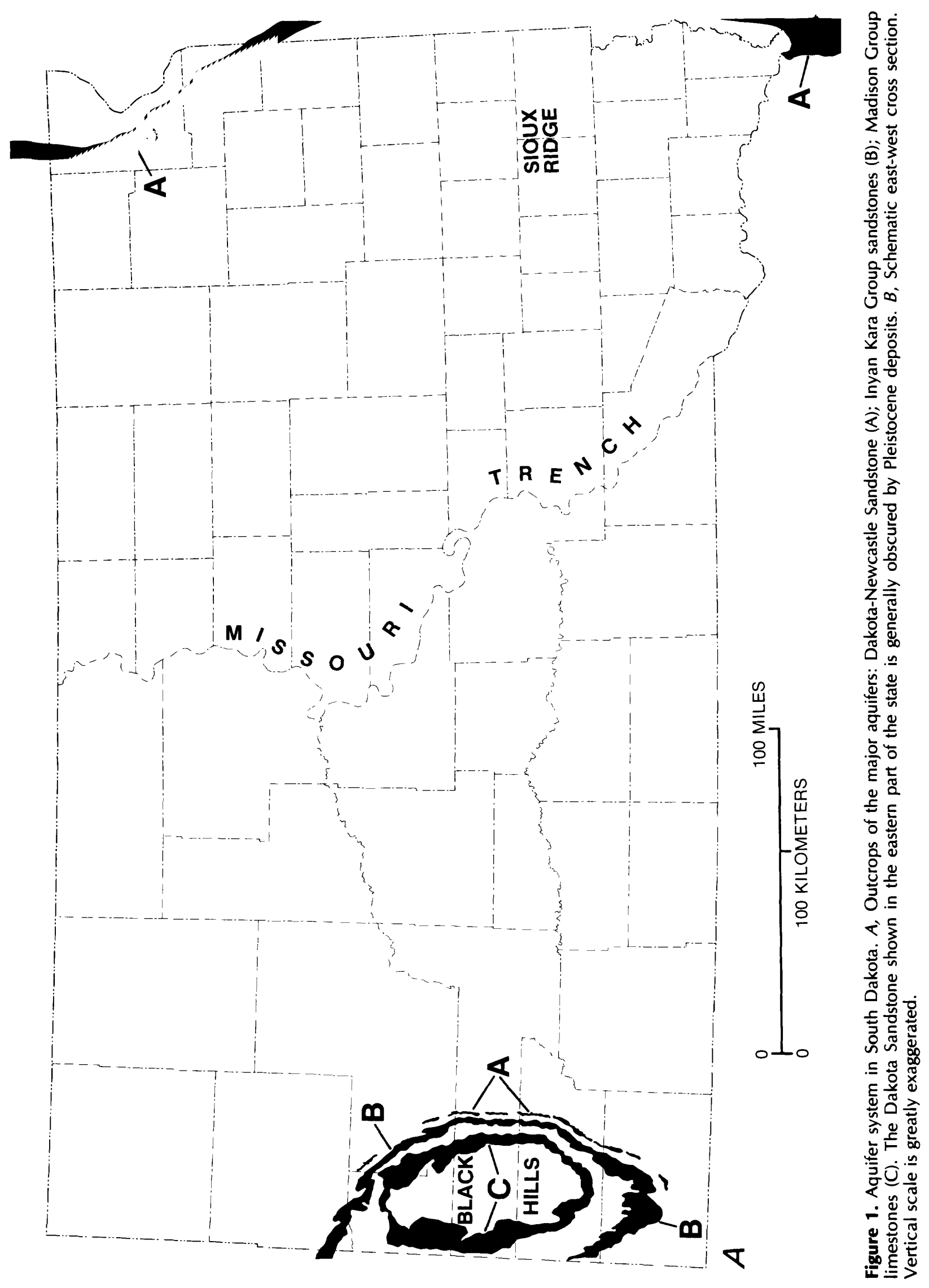




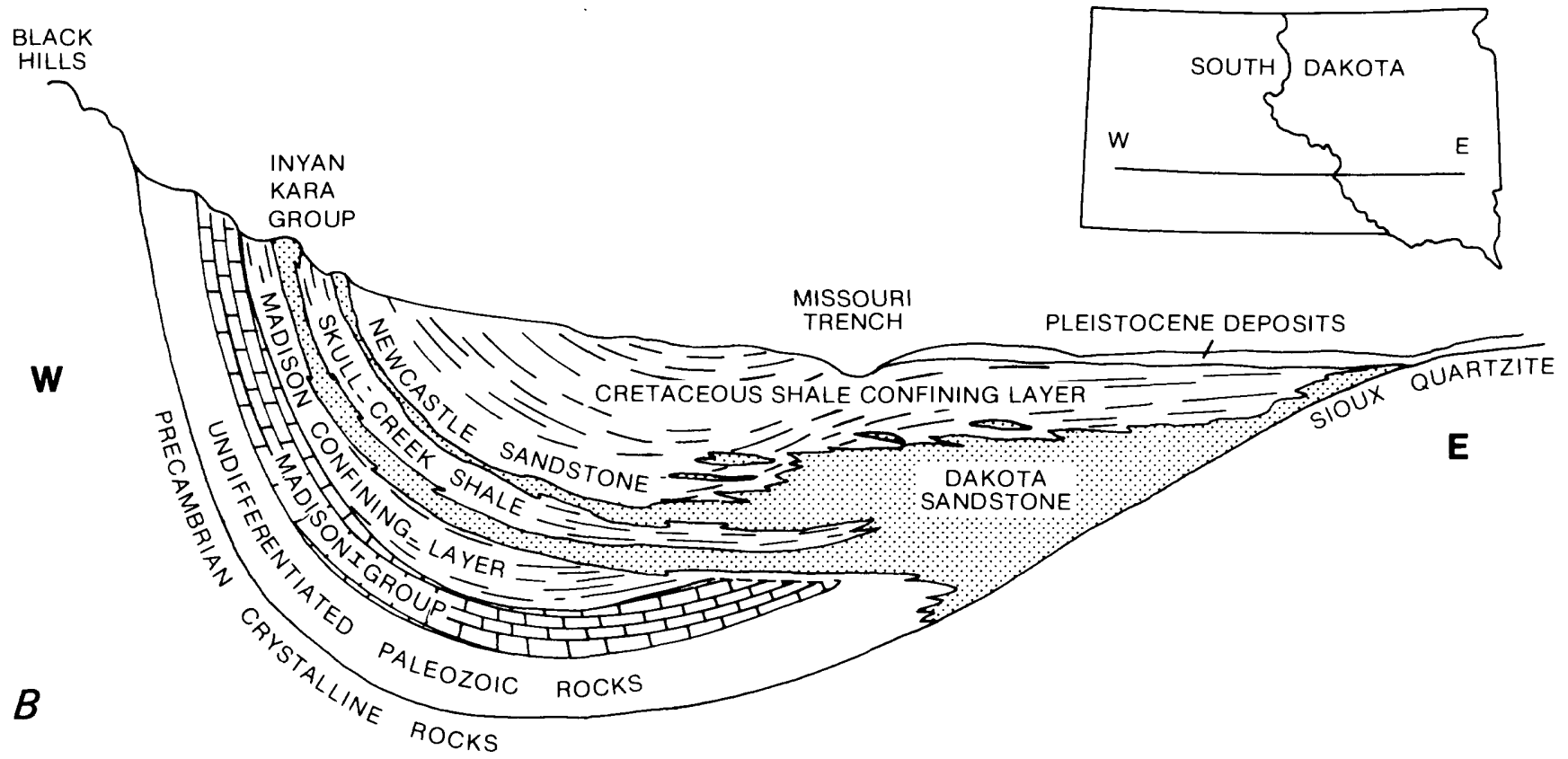

Figure 1. Continued.

raphy, Darton's $(1901,1909)$ conception of the gross ground-water flow in the system was much the same as is understood today. The aquifers are partly recharged at high elevations around the Black Hills and conduct water toward the east. In eastern South Dakota, outcrops permit discharge. Darton $(1909$, p. 60$)$ believed recharge and discharge also occur by leakage through confining layers, as pointed out above.

Separating the major aquifers are confining layers of low-permeability rock. The confining layer overlying the Madison, in this report called the "Madison confining layer," encompasses the section from the top of the Mississippian carbonate rocks to the base of the Inyan Kara Group sandstones and includes some aquifers of minor importance. Swenson (1968) suggested that the Madison subcrops directly beneath parts of the Inyan Kara. The Madison confining layer thins eastward, but significantly different potentiometric heads in the Madison and Inyan Kara indicate that it completely separates them.

The Skull Creek Shale separates the Inyan Kara Group from the overlying Dakota-Newcastle Sandstone. It thins eastward and eventually pinches out, which allows the Inyan Kara and Newcastle sands to merge, forming the Dakota Sandstone of eastern South Dakota (Gries, 1958; Schoon, 1971).

To carry out our investigation, it was necessary to estimate the transmissivity and its areal variation in each aquifer. The thickness of the aquifers was, therefore, important, and isolith maps of the units were prepared, largely from a regional selection of electric logs. The isolith map of the Inyan Kara Group is shown in figure 2. Figure 3 is the isolith map of the Dakota-Newcastle Sandstone.

As noted above, Gries (1958) indicates that the Newcastle Sandstone is quite thin and may be discontinuous in western South Dakota. However, subsurface correlations suggest that the sandstones tend to be continuous; at least within certain stratigraphic intervals, sand bodies tend to be present. The density of control is not sufficient to indicate whether individual sand bodies are isolated from one another. However, these intervals are zones of higher permeability which contain sufficiently large percentages of sand to make it reasonable to expect each to be hydraulically continuous.

The confining layer overlying the Dakota, which we call the "Cretaceous shale confining layer," includes the entire sequence above the Dakota-Newcastle Sandstone. Sedimentary rocks from this dominantly shale sequence crop out over much of South Dakota. Although predominanted by shales, the Cretaceous shale confining layer contains several minor aquifers, most important of which are the Niobrara Formation (predominantly chalk) and the Greenhorn Limestone.

The outcrops of the Niobrara and Greenhorn aquifers are shown in figure $4 A$; the stratigraphy of the Cretaceous shale confining layers is presented schematically figure $4 B$. Like the Dakota-Newcastle Sandstone, the Niobrara Formation and Greenhorn Limestone aquifers both crop out on the flanks of the Black Hills and again in the extreme eastern part of the State; the Niobrara Formation also crops out in the 


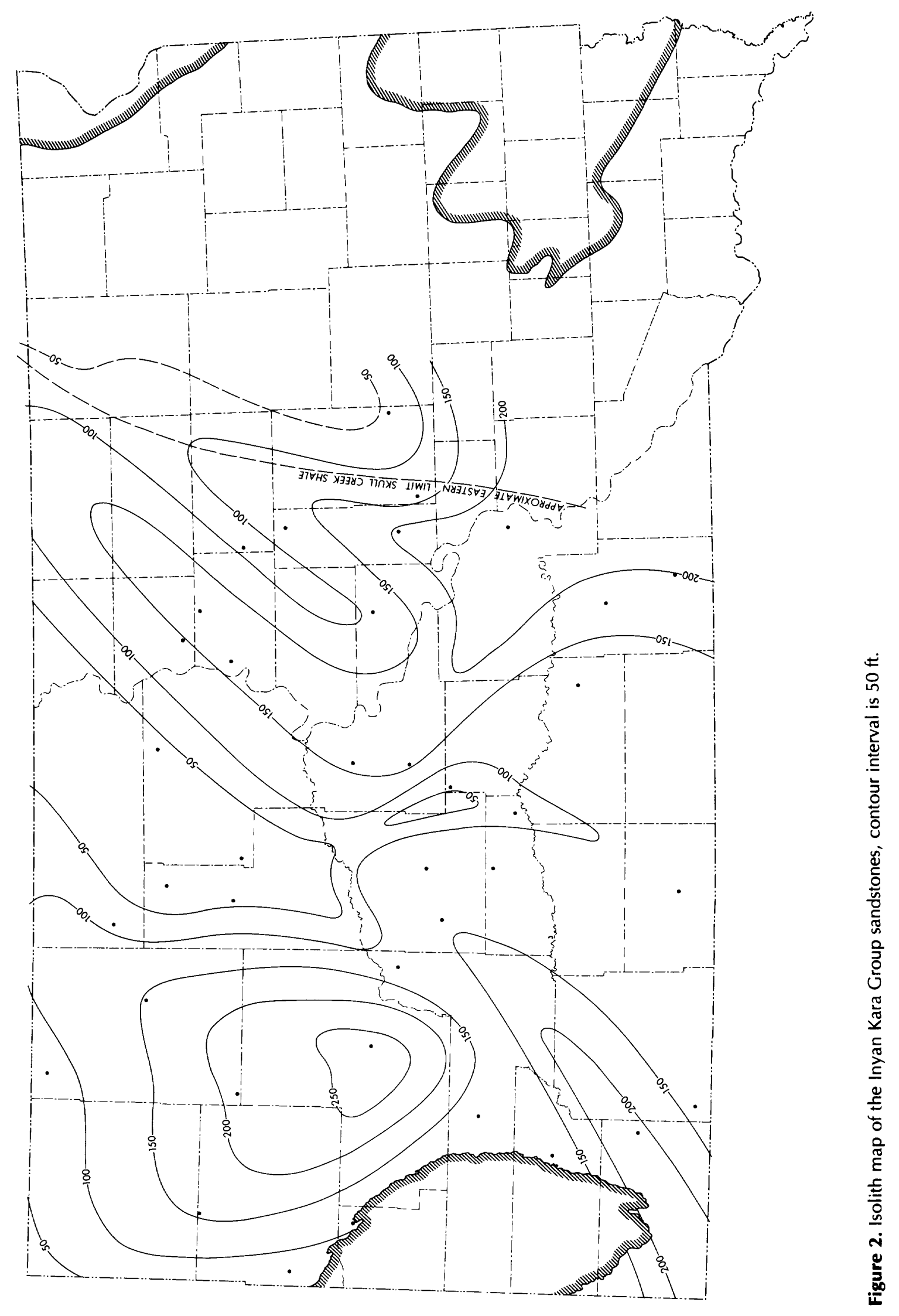




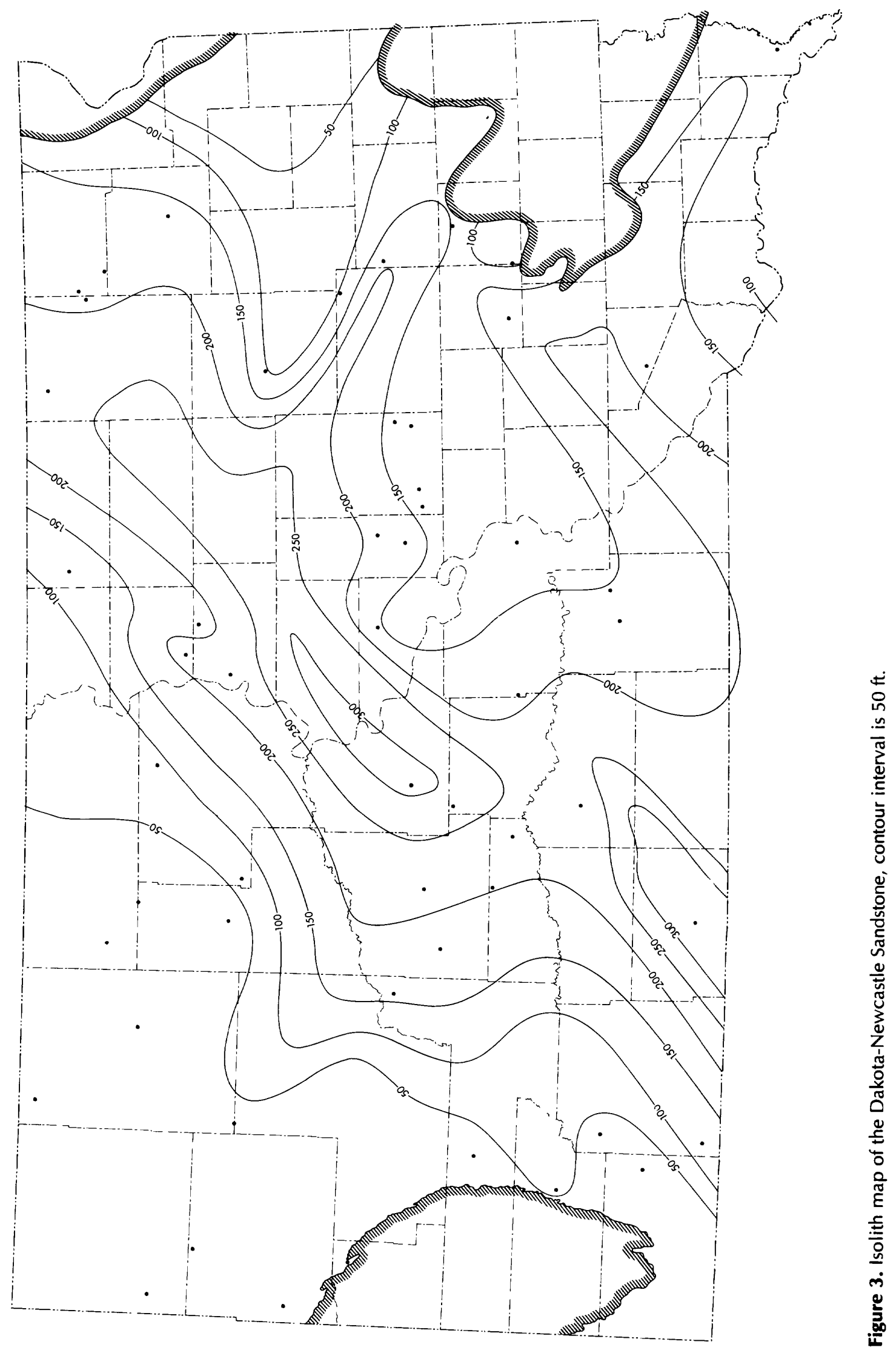

7 
southern part of the Missouri Trench and the James River valley. Three Cretaceous shales, the Mowry-Belle Fourche, Carlile, and Pierre, constitute the bulk of the sedimentary sequency overlying the Dakota-Newcastle Sandstone.

Schultz (1964, 1965), Tourtelot (1962), Gill and Cobban $(1965,1966)$, and others have extensively studied the Pierre and other Cretaceous shales in the outcrop areas. However, much still remains to be learned about them, particularly in the subsurface. Data on the subsurface are almost exclusively from geophysical logs. Prior to this investigation, only one relatively complete core of the Pierre section in South Dakota had been taken (Tourtelot and Schultz, 1961), the Irish Creek oil test core of 1925 . Well logs and shallow coring data from engineering studies are available. However, the bulk of the information is from surface outcrops of more or less weathered shale. Our experience with cores indicates that the shale alters rapidly on exposure; even fresh outcrops offer only limited insight into the physical properties of the shale at depth.

\section{Hydraulic Conductivity of the Dakota Aquifer}

In an effort to estimate the hydraulic conductivity of the Dakota aquifer, approximately 1,100 drilling records of the Norbeck and Hollis Drilling Company were carefully examined. In general, the drillers reported the following information:

1. The location, usually to within 10 acres by township and range,

2. The total well depth,

3. The length and diameter of the various sizes of pipe used to case the hole,

4. The length, size, and position in the hole of the perforated pipe used to screen the aquifer,

5. An estimate of the rate of flow of the well, and

6. The date of both the start and completion of the work.

It is possible to use the discharge of a flowing well to estimate the transmissivity of that portion of the aquifer screened. The equation which describes the discharge of a flowing artesian well in an infinite aquifer was derived by Jacob and Lohman (1952):

$$
\mathrm{Q}=2 \pi \mathrm{TG}(\alpha) \delta_{\mathrm{w}},
$$

where $Q$ is rate of flow $\left(\mathrm{L}^{3} / \mathrm{T}\right)$,

$T$ is aquifer transmissivity $\left(\mathrm{L}^{2} / \mathrm{T}\right)$,

$\delta_{w}$ is drawdown in the discharging well, constant in this case (L), and

$$
\begin{gathered}
\mathrm{G}(\alpha) \text { is }(4 \alpha / \pi) \int_{0}^{\infty} \mathrm{x} \exp \left(-\alpha \mathrm{x}^{2}\right)\{(\pi / 2) \\
\left.+\tan ^{-1}\left[\mathrm{Y}_{0}(\mathrm{x}) / \mathrm{J}_{0}(\mathrm{x})\right]\right\} \mathrm{dx} .
\end{gathered}
$$

$\mathrm{J}_{0}(\mathrm{x})$ and $\mathrm{Y}_{0}(\mathrm{x})$ are Bessel functions, zero order, first and and second kinds, respectively. The dimensionless quantity $\alpha$ is defined by

$$
\alpha=\mathrm{Tt} / \mathrm{Sr}_{\mathrm{w}}{ }^{2},
$$

where $\mathbf{S}$ is storage coefficient (dimensionless),

$t$ is time ( $T$ ), and

$r_{w}$ is effective radius of the discharging well $(L)$.

After some time, which usually is not long for a flowing well, $\mathrm{G}(\alpha)$ can be approximated by

$$
\mathrm{G}(\alpha) \cong 2 /\left[\ln \left(2.25 \mathrm{Tt} / \mathrm{r}_{\mathrm{w}}{ }^{2} \mathrm{~S}\right)\right] .
$$

By substituting 2 into 1 , we obtain

$$
\mathrm{Q}=4 \pi \mathrm{T} \gamma_{\mathrm{w}} /\left[\ln \left(2.25 \mathrm{Tt} / \mathrm{r}_{\mathrm{w}}{ }^{2} \mathrm{~S}\right)\right],
$$

which can be rearranged to give

$$
\mathrm{Q} / \mathrm{\gamma}_{\mathrm{w}}=4 \pi \mathrm{T} /\left[\ln \left(2.25 \mathrm{Tt} / \mathrm{r}_{\mathrm{w}}{ }^{2} \mathrm{~S}\right)\right] \text {. }
$$

This is the same relationship as the so-called specific capacity equation suggested by Theis and others (1963) for a well pumped at a constant rate.

The relationship between $Q / \delta_{w}$ and $T$, as expressed by equation 3 , is graphed in figure 5 . This graph may be used to estimate the transmissivity of the aquifer. As figure 5 suggests, the relationship is not sensitive to a variation in the storage coefficient. According to the drillers, wells drilled into the Dakota aquifer take 4 to $5 \mathrm{hr}$ to complete. Thus, flow rates were estimated after approximately $4.5 \mathrm{hr}$ of flow, and the graphs are computed for $270 \mathrm{~min}$.

The rate of flow, $Q$, was estimated by the drillers; however, the drawdown, $\delta_{w}$, was not measured. The potential drawdown was estimated by taking the difference between the land surface elevation and Darton's (1909) potentiometric surface:

$$
\delta_{\max }=h_{0}-h_{l s},
$$

where $\delta_{\max }$ is the maximum possible drawdown (L),

$h_{0}$ is potentiometric head (L) as given by Darton's (1909) map, and

$h_{l s}$ is the land surface elevation (L).

Many of the Dakota wells are very small in diameter; commonly these wells are cased with approximately 800 to 1,000 feet of 1.25 -in. diameter pipe. This causes large friction losses in the well itself. The maximum drawdown was, therefore, corrected for friction losses and is given by 


$$
\delta_{\mathrm{w}}=8_{\mathrm{max}}-8_{\mathrm{f} l},
$$

where $z_{f l}$ is the loss in head due to friction losses in the casing (L).

It was not uncommon to find in the drilling data that the computed friction losses were greater than the available head. This probably indicates that the driller did not make a reliable flow estimate. In some cases, error in the estimates of $h_{0}$ and $h_{l s}$ or in the completion time may have been significant. Such data were discarded. Discarding this portion of the data preferentially removed only errors of overestimated flow; however, these probably represent the majority of errors. Overestimates of well yields were probably more common than underestimates.

The drilling data also provided a crude check of Darton's map. Wells should flow only where the aquifer potentiometric surface is above the land surface elevation. This check indicated that Darton's map is reliable in the areas of development.

The transmissivity was estimated using the relationship shown in figure 5. Transmissivity estimates were then divided by the interval screened in the well to obtain an estimate of the hydraulic conductivity. The conductivity estimates are summarized by counties in table 1. In Beadle, Brown, and Spink Counties, transmissivity estimates were computed for approximately 100 wells in each county. Approximately 500 records were thought to give reasonably reliable results; of these, about 300 were thought to be very good. The distribution of the most reliable data is shown in figure 6 .

Unfortunately, most of the highly reliable data are in a limited area in northeast South Dakota, which pro-

Table 1. Summary of hydraulic conductivity estimates for the Dakota Sandstone

\begin{tabular}{|c|c|c|c|}
\hline County & $\begin{array}{c}\text { Number of } \\
\text { wells }\end{array}$ & $\begin{array}{c}\text { Mean hydraulic } \\
\text { conductivity } \\
\left(10^{-5} \mathrm{ft} / \mathrm{sec}\right)\end{array}$ & $\begin{array}{c}\text { Standard } \\
\text { deviation } \\
\left(10^{-5} \mathrm{ft} / \mathrm{sec}\right)\end{array}$ \\
\hline Beadle--_-_-_-_-_ & 112 & 6.7 & 6.0 \\
\hline Brown-_-_-_-_- & 110 & 5.4 & 6.2 \\
\hline Clark-_-_-_ & 6 & 3.0 & 2.2 \\
\hline Edmunds --_------ & 5 & 3.0 & 1.4 \\
\hline Faulk--_-_-_-_-_-- & 75 & 7.0 & 7.1 \\
\hline Hand--_-_-_-_-- & 11 & 11.0 & 8.8 \\
\hline Kingsbury--_------- & 41 & 2.1 & 2.9 \\
\hline Marshall and Day ---- & 20 & 3.5 & 3.5 \\
\hline Sandborn and Miner -- & 10 & 3.9 & 5.5 \\
\hline Spink - - & 88 & 11.0 & 11.0 \\
\hline Stanley and Hughes -- & 7 & 5.7 & 6.4 \\
\hline Sully --_-_-_- & 9 & 2.1 & 3.0 \\
\hline $\begin{array}{l}\text { Mean for all wells } \\
\text { (total 494) }\end{array}$ & - & 6.4 & 7.1 \\
\hline
\end{tabular}

Table 2. Summary of Niven's (1967) hydraulic conductivity data for samples obtained from Black Hills outcrops of the Newcastle Sandstone and Inyan Kara Group sandstones

\begin{tabular}{lccc}
\hline Formation & $\begin{array}{c}\text { Number of } \\
\text { samples }\end{array}$ & $\begin{array}{c}\text { Mean hydraulic } \\
\text { conductivity } \\
\text { (ft/sec) }\end{array}$ & $\begin{array}{c}\text { Mean porosity } \\
\text { (percent) }\end{array}$ \\
\hline $\begin{array}{l}\text { Lakota --_---- } \\
\text { Fuson member of }\end{array}$ & 202 & $26 \times 10^{-5}$ & 28.5 \\
$\quad$ Lakota formation - & 19 & $3.1 \times 10^{-5}$ & 19.4 \\
Fall River ----- & 86 & $5.6 \times 10^{-5}$ & 23.8 \\
Newcastle--- & 10 & $1.7 \times 10^{-5}$ & 19.1 \\
\hline
\end{tabular}

vides a poor areal distribution for the entire State. A statistical test was made on the data in table 1 to see if significant differences exist between counties. This test indicated significant differences at the 95-percent confidence level. This, of course, suggests that areal variations in aquifer hydraulic conductivity exist.

Considerable study was done to see if differences in the hydraulic conductivity in the area of high data density coincided with some feature of the geology such as a general east-west facies change. Figure 6 also shows third-degree polynomial trend surfaces computed from subsets of the hydraulic conductivity data. The results of these efforts were disappointing; we were unable to find similar patterns in conductivity and a mappable geologic feature.

Table 2 is a summary of Niven's (1967) measurements of hydraulic conductivity of the Newcastle and Inyan Kara Group sandstones from outcrop samples taken in the Black Hills. Niven's data indicate somewhat higher conductivities in the Black Hills than the subsurface data. It is encouraging, however, that the hydraulic conductivities computed from the well completion reports and Niven's results are within an order of magnitude. One would expect the outcrop to yield higher hydraulic conductivities than exist in the subsurface. Niven (1967) states,

"Outcrop permeability of the formations is much greater than in the subsurface, and this is attributed to removal of cement by weathering."

A 44-hr pumping test was run at the town of Wall, South Dakota, by Gries and others (1976). They analyzed the test utilizing the Theis (1935) solution, which does not consider leakage or storage in the confining layers. Their analysis yielded an average of $1.5 \times 10^{-5} \mathrm{ft} / \mathrm{sec}$ hydraulic conductivity for the combined $230 \mathrm{ft}$ of both the Newcastle and the Inyan Kara aquifer open to the well.

The data from the Wall test can also be analyzed using the modified leaky aquifer theory, which includes the effects of both leakage from and storage within the 


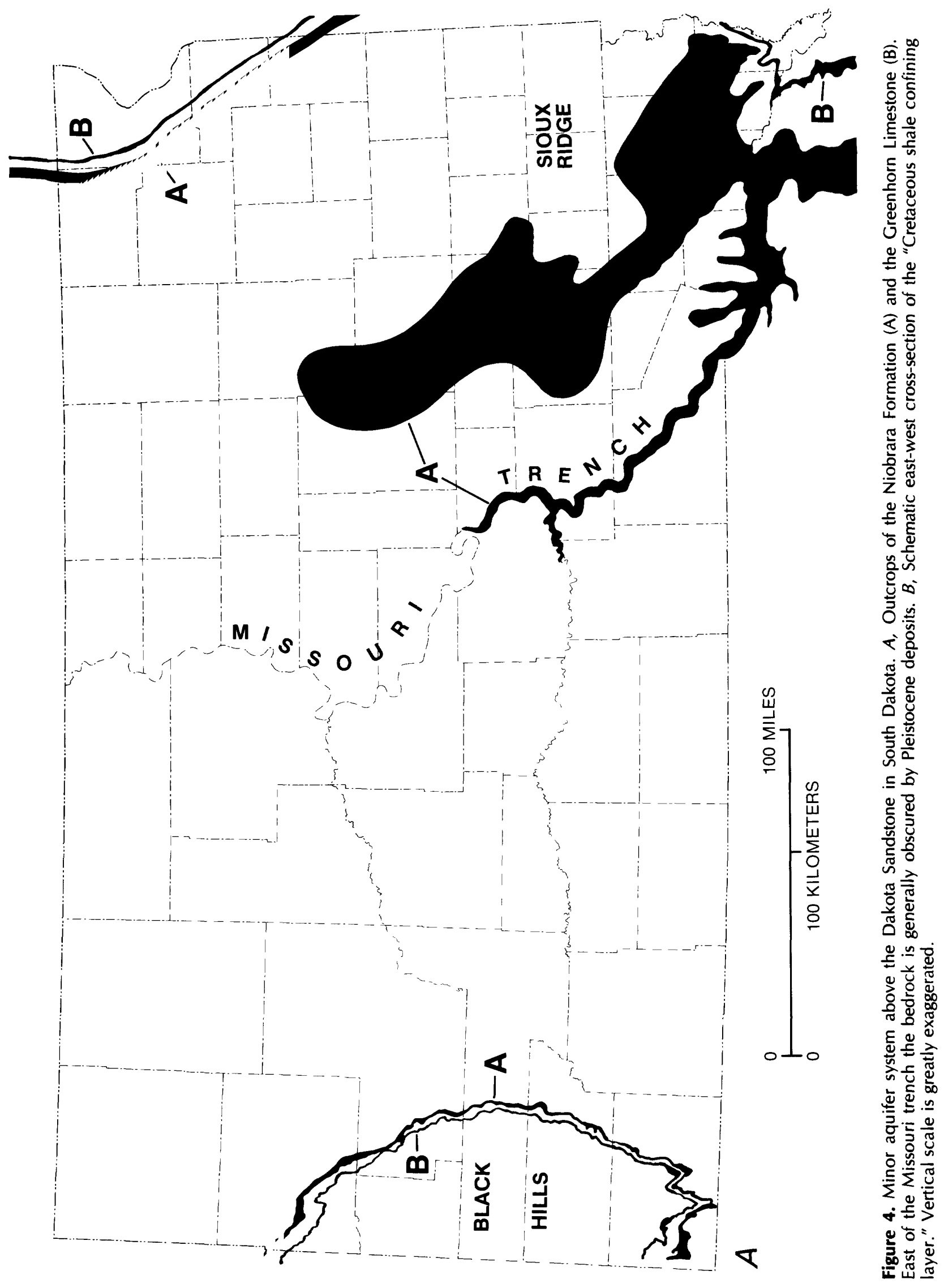




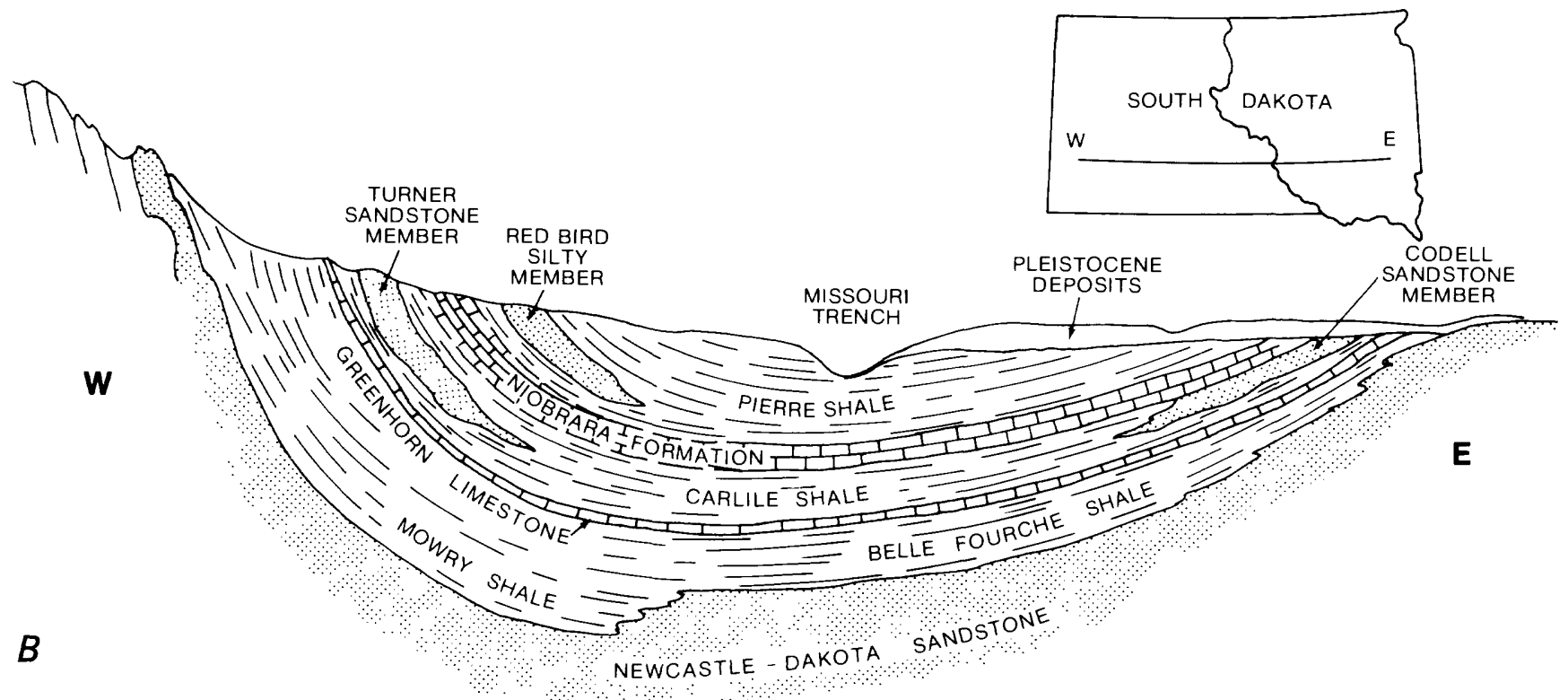

Figure 4. Continued.

confining layers (Hantush, 1960). Such an analysis reduces the calculated hydraulic conductivity to $6.5 \times 10^{-6} \mathrm{ft} / \mathrm{sec}$.

A single well pumping test was conducted in the Inyan Kara aquifer at the town of Box Elder, South Dakota, by Miller and Rahn (1974). Utilizing the Theis recovery method of analysis, this test yielded an average hydraulic conductivity of $1.1 \times 10^{-5} \mathrm{ft} / \mathrm{sec}$.

The data suggest that the hydraulic conductivity of the Dakota, Newcastle, and Inyan Kara sandstones ranges from approximately $5 \times 10^{-6}$ to $3 \times 10^{-4} \mathrm{ft} / \mathrm{sec}$. The average value of $6 \times 10^{-5} \mathrm{ft} / \mathrm{sec}$, computed from approximately 500 drilling records, seems reasonable for a representative value of hydraulic conductivity for the Dakota and equivalent sandstone aquifers.

\section{SIMULATION OF REGIONAL FLOW}

Compared with ground-water flow rates in the aquifers, rates of leakage through the confining layers are quite small. However, the confining layer leakage can be important. Over large areas with significant vertical hydraulic gradients, even very small hydraulic conductivities permit significant amounts of leakage; this leakage, in turn, may control the regional flow. Thus, to simulate the behavior of an aquifer and confining layer system, one must often account for the leakage through the confining layers.

The partial differential equation which describes the nonsteady flow of ground water in a system involv- ing an aquifer bounded by confining layers such as shown schematically in figure 7 is

$$
\frac{\partial}{\partial x}\left[T_{x x} \frac{\partial h}{\partial x}\right]+\frac{\partial}{\partial y}\left[T_{y y} \frac{\partial h}{\partial y}\right]=S \frac{\partial h}{\partial t}+W
$$

where $\mathrm{T}$ is the transmissivity of the aquifer, a secondrank symmetric tensor $\left(\mathrm{L}^{2} / \mathrm{T}\right)$,

$h$ is the potentiometric head in the aquifer $(L)$, and

$\mathrm{S}$ is the aquifer storage coefficient (dimensionless).

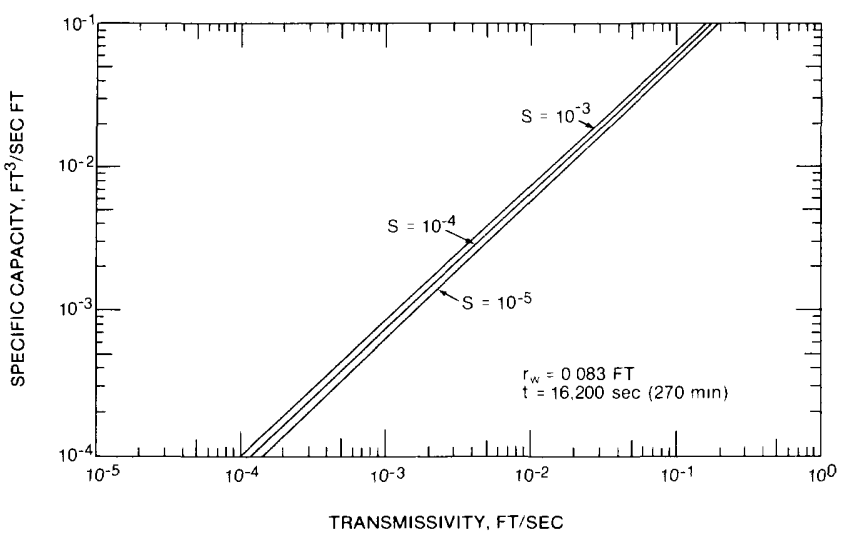

Figure 5. Specific capacity versus transmissivity for a flowing well. 

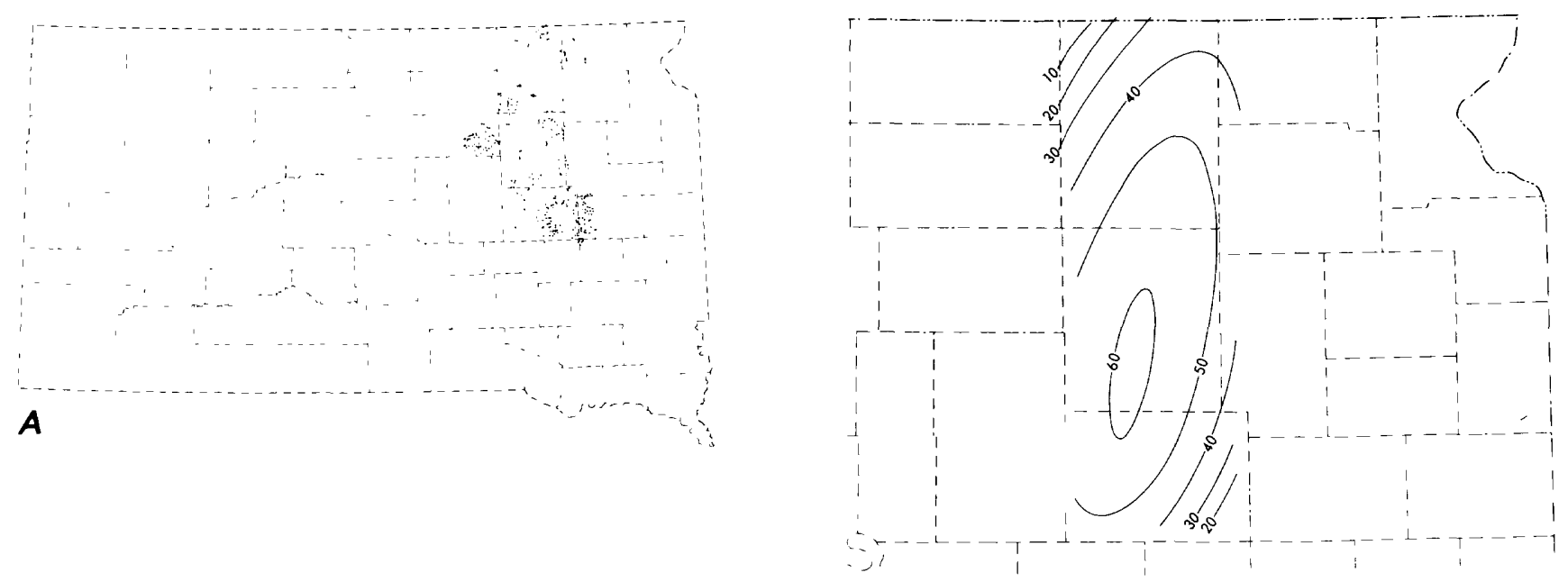

$\boldsymbol{B}$

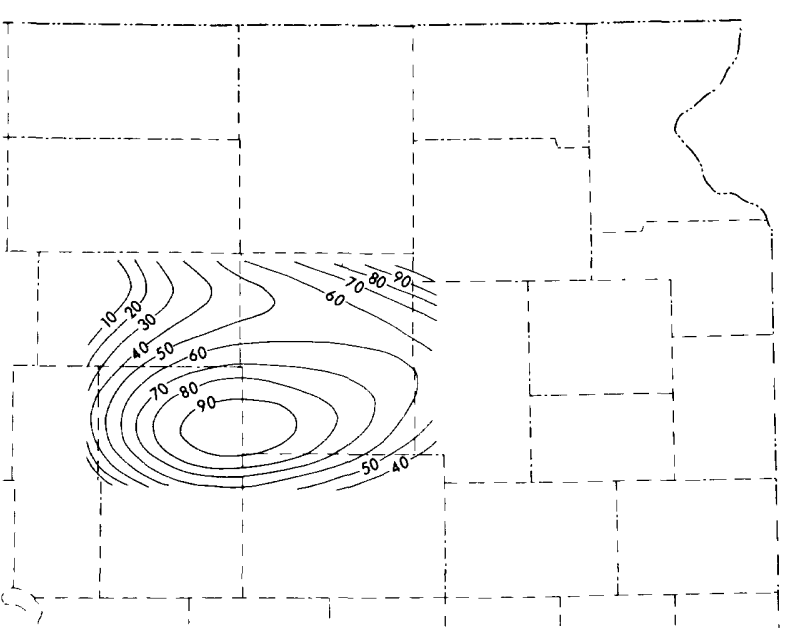

C

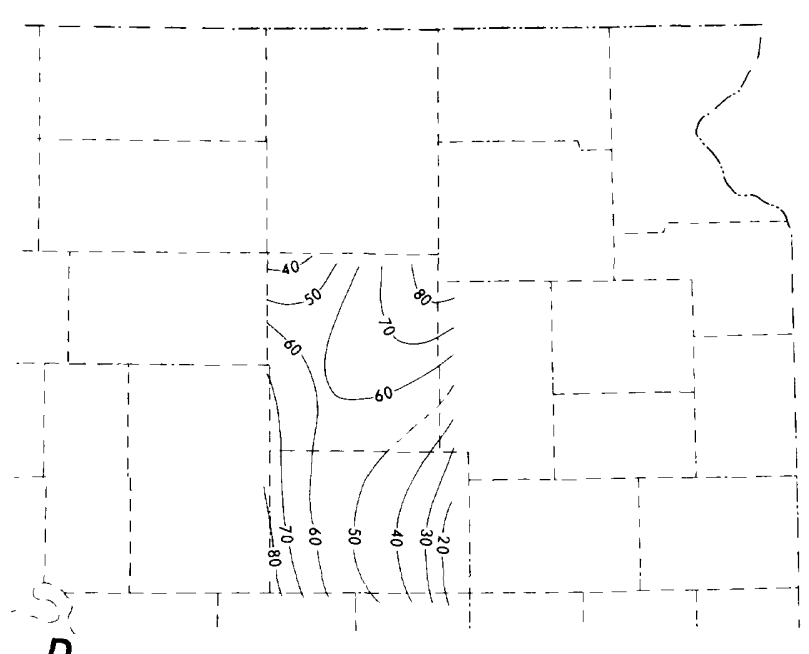

D

Figure 6. Hydraulic conductivity data from drilling reports. $A$, Distribution of most reliable data. $B, C, D$, Third-degree polynominal trend surfaces computed from different subsets of the data.

For steady flow, $S \partial \mathrm{h} / \partial \mathrm{t}$ is 0 , and the source function, $\mathrm{W}$, is given by

$$
\mathrm{W}=-\mathbf{K}_{\mathrm{z}} \frac{\mathbf{h}_{\mathrm{wt}}-\mathbf{h}}{l}
$$

where $\mathbf{K}_{\mathbf{z}}^{\prime}$ is the vertical hydraulic conductivity of the confining layer $(\mathrm{L} / \mathrm{T})$,

$l$ is the thickness of the confining layer $(\mathrm{L})$, and

$h_{w t}$ is the elevation of the water table (L).

Using equations 6 and 7, the ground-water flow system can be analyzed, provided the initial and boundary conditions and the following parameters and their distribution are known:

1. The transmissivity and storage coefficient of the aquifer,
2. The vertical hydraulic conductivity of the confining layer,

3. The thickness of the confining layer, and

4. The water table elevation.

If the aquifer potentiometric surface at some time is known, it is possible either by trial and error or by some formal mathematical procedure to estimate the values of one of the parameters, usually either the aquifer transmissivity or the hydraulic conductivity of the confining layer. Values of the parameters are adjusted to obtain the best agreement between the observed and computed potentiometric surfaces in the aquifer. In practice, one usually adjusts all the variables using knowledge of the geology of the system to judge the reasonableness of changes.

Commonly, the aquifer system has been disturbed by ground-water withdrawal and is no longer in a steady state condition $(S \partial h / \partial t \neq 0)$. Analysis of the transient 
state provides estimates of the storage properties of the aquifers and confining layers.

Transient vertical leakage in the confining layers is governed by

$$
\frac{\partial^{2} h}{\partial z^{2}}=\frac{S_{s}^{\prime}}{K_{z}^{\prime}} \frac{\partial h}{\partial t},
$$

where $\mathrm{S}_{s}$ ' is the specific storage $\left(\mathrm{L}^{-1}\right)$ and $z$ is vertical distance in the confining layer.

The gradient of potentiometric head in the confining layer at the boundary with the aquifer, $\partial \mathrm{h}(\mathrm{z}, \mathrm{t}) / \partial \mathrm{z}$ at $z=0$, is determined by equation 8 and its initial and boundary conditions. The boundary conditions are the potentiometric heads in the adjoining aquifers. The source function, $\mathrm{W}$, is then given by

$$
\mathrm{W}=-\left.\mathrm{K}_{\mathrm{z}}^{\prime} \frac{\partial \mathrm{h}(\mathrm{z}, \mathrm{t})}{\partial \mathrm{z}}\right|_{\mathrm{z}=0}
$$

Methods can be introduced to calculate the transient source function using equations 8 and 9 and thus account for the effect of storage in the confining layer. In the case of the Dakota, storage within the confining layers is an important part of the analysis, as will be shown below.

\section{Model Analysis}

Four conceptual models of the Dakota aquifer system have been used as bases for numerical simulations of the flow. These evolved from a simple model in which the Inyan Kara Group and the Dakota-Newcastle Sandstone were considered a single aquifer underlain by impermeable rocks and overlain by a single homogeneous confining layer of varying thickness (the conceptual model shown in fig. 7). The second model included a second aquifer below the Dakota representing

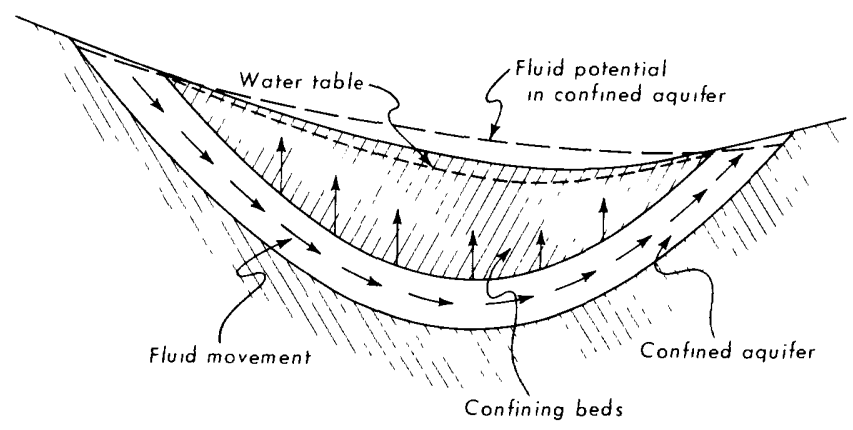

Figure 7. Diagrammatic cross section of the simplest conceptual model used to analyze the Dakota aquifer. the Madison Group aquifer. The next refinement, which resulted in the third model, was a third aquifer in the western part of South Dakota where the Newcastle and Inyan Kara sandstones are distinct. In terms of the Cretaceous confining layer, a further refinement was introduced by subdividing the confining layer in a fourth model which included only one major aquifer, the Dakota-Newcastle Sandstone. The confining layer was subdivided, as shown in figure $4 B$, into the Pierre Shale; the Niobrara Formation, an aquifer; the Carlile Shale; the Greenhorn Limestone, also an aquifer; and the Mowry-Belle Fourche Shale.

In all the analyses, the computed potentiometric surface for the aquifers was found to be quite sensitive to $\mathrm{K}_{\mathrm{z}}^{\prime}$, the confining layer vertical hydraulic conductivity, indicating that the confining layers and the aquifers interacted significantly and that leakage through the confining layers is an important aspect of system behavior. In transient simulations, it was found that, if leakage from storage in the confining layers was not included, drawdowns were much too large.

The ground-water equations were solved using the quasi-three-dimensional finite-difference model by Trescott (1975), which was derived from that of Bredehoeft and Pinder (1970). Each aquifer is represented by a single layer of block-centered nodes. The variable aquifer thickness is accounted for by specifying the value of transmissivity for each block. For multiple aquifers, the model is actually a sequence of two-dimensional aquifer layers coupled to simulate flow through the intervening confining beds.

The grids used for numerical simulations in all of the models were oriented approximately along the cardinal directions with equal grid spacing in the northsouth and east-west directions. The grid for the first three models was 50 blocks east-west by 36 blocks north-south and covered an area somewhat larger than South Dakota; the blocks were approximately $8.3 \mathrm{mi}$ on a side. The grid for the fourth, or Cretaceous confining layer model, was twice as coarse and contained 25 by 18 nodes.

Figure 8 shows the arrangement of the finitedifference grids for the third, or three-aquifer, model. Constant head boundaries were placed at areas of aquifer outcrop; the potentiometric heads assigned represented the elevation at which recharge or discharge occurred. The north and south model boundaries, which are approximately parallel to the general flow from west to east, were treated as impermeable or noflow boundaries. The eastern no-flow boundary of the Madison layer represented the truncation of the Madison rocks beneath the Madison confining layer. That of the Inyan Kara layer was placed where the Inyan Kara and Dakota merge; east of this boundary, the Dakota layer included both. 


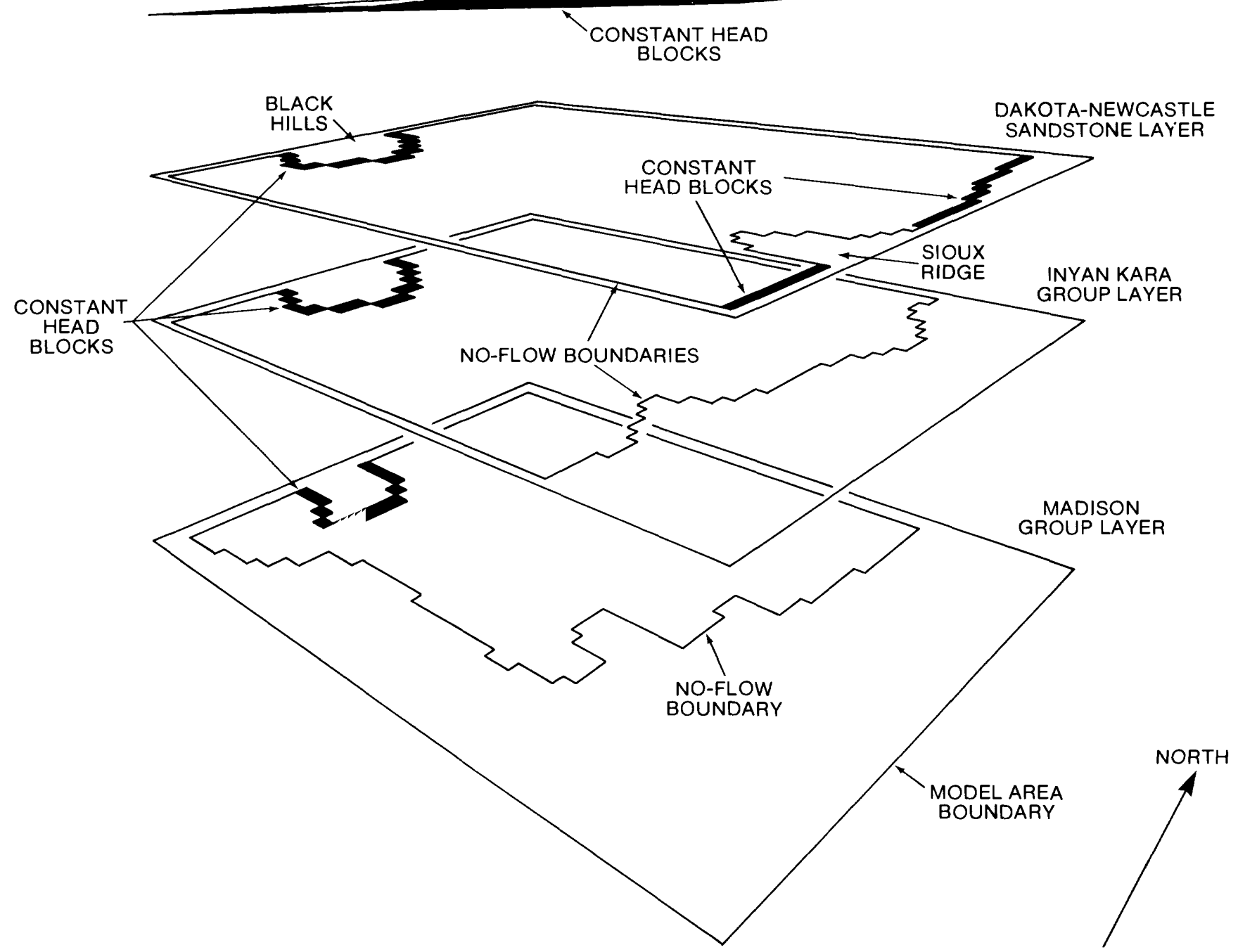

Figure 8. Schematic depiction of the arrangement of finite-difference grids used for the three-aquifer model of the Dakota system (third model). The view is from the southeast. The areas of constant head blocks on the left represent outcrop areas around the Black Hills; constant head blocks on the right in the Dakota layer represent outcrops in eastern South Dakota. The water table layer consists of constant head blocks representing the elevation of the water table.

The uppermost (water table) layer shown in figure 8 allowed leakage across the Cretaceous shale confining layer. The constant potentiometric heads in this layer represented the water table elevation and were approximated by the land surface elevation.

Numerical analysis of the system as idealized in the models was accomplished using values for parameters which were known (aquifer hydraulic conductivity, aquifer and confining layer thickness, water table elevation, aquifer boundary conditions) and adjusting the confining layer hydraulic conductivity until a good match between computed and observed potentiometric head in the aquifer was obtained. In practice, conductivities in the other aquifers, about which less is known than the Dakota-Newcastle, were also adjusted somewhat.

A number of different conditions were simulated for the Dakota aquifer using the technique described briefly above. An attempt was first made to solve for virgin (steady-flow) conditions prior to development by adjusting leakage through the confiing layers until the computed potentiometric surface in the Dakota matched the potentiometric map published by Darton (1909, Plate XI; see figure $12 A$, this report).

We have made the assumption that Darton's map approximates conditions prior to withdrawal of ground water. Because Darton's potentiometric surface was mapped after some development, one would expect the 
virgin surface to be somewhat higher than the surface mapped by Darton and shown in figure $12 \mathrm{~A}$. However, comparison of Darton's map data and the records of the State Engineer reveal that Darton used data from some of the earliest wells drilled. It seems reasonable to assume that Darton's potentiometric surface closely approximates predevelopment conditions.

Results of computations using the first (singleaquifer) model clearly illustrate the importance of leakage through the Cretaceous shale confining layer. To facilitate comparison of the results of several computations, it is convenient to plot the potentiometric head relative to land surface; figure 9 is a plot of Darton's 1909 potentiometric surface utilizing land surface as the datum. Figure 10 is a similar plot of the virgin potentiometric head relative to the land surface, computed with a vertical hydraulic conductivity for the combined Cretaceous shale confining layer of $5 \times 10^{-9} \mathrm{ft} / \mathrm{sec}$. With this conductivity, the system would not maintain heads much above the land surface and certainly not nearly as high as Darton's data indicate. As smaller vertical hydraulic conductivities were used for the confining layer, higher potentiometric heads in the aquifer were computed. Simulations for the first model computed poten- tiometric heads approximating those measured by Darton with a confining layer conductivity of $5 \times 10^{-11} \mathrm{ft} / \mathrm{sec}$ (fig. 11). The agreement between Darton's data (fig. 9) and the computed values (fig. 11) is surprisingly good.

The virgin potentiometric surface computed using the third, or three-aquifer (Dakota, Inyan Kara, Madison), model is compared directly with the potentiometric surface, published by Darton, in figure 12. The simulation gives results which we believe to be in good agreement with Darton's measurements in the areas where he had data. Most of Darton's data are restricted to the area east of the Missouri River.

A transient-flow analysis was performed in an effort to investigate the importance of ground-water withdrawal. Transient conditions were simulated in all but the fourth model. However, the most complete discharge data and most accurate approximation of flow in the confining layers were used in conjunction with the third model; we will discuss these results.

Records in the annual and biennial reports of the South Dakota State Engineer show that recorded well discharge increased from zero in 1881 to approximately 370 million gal/d in 1912 and then declined dramatically to approximately 80 million gal/d in 1922 (fig. 13).

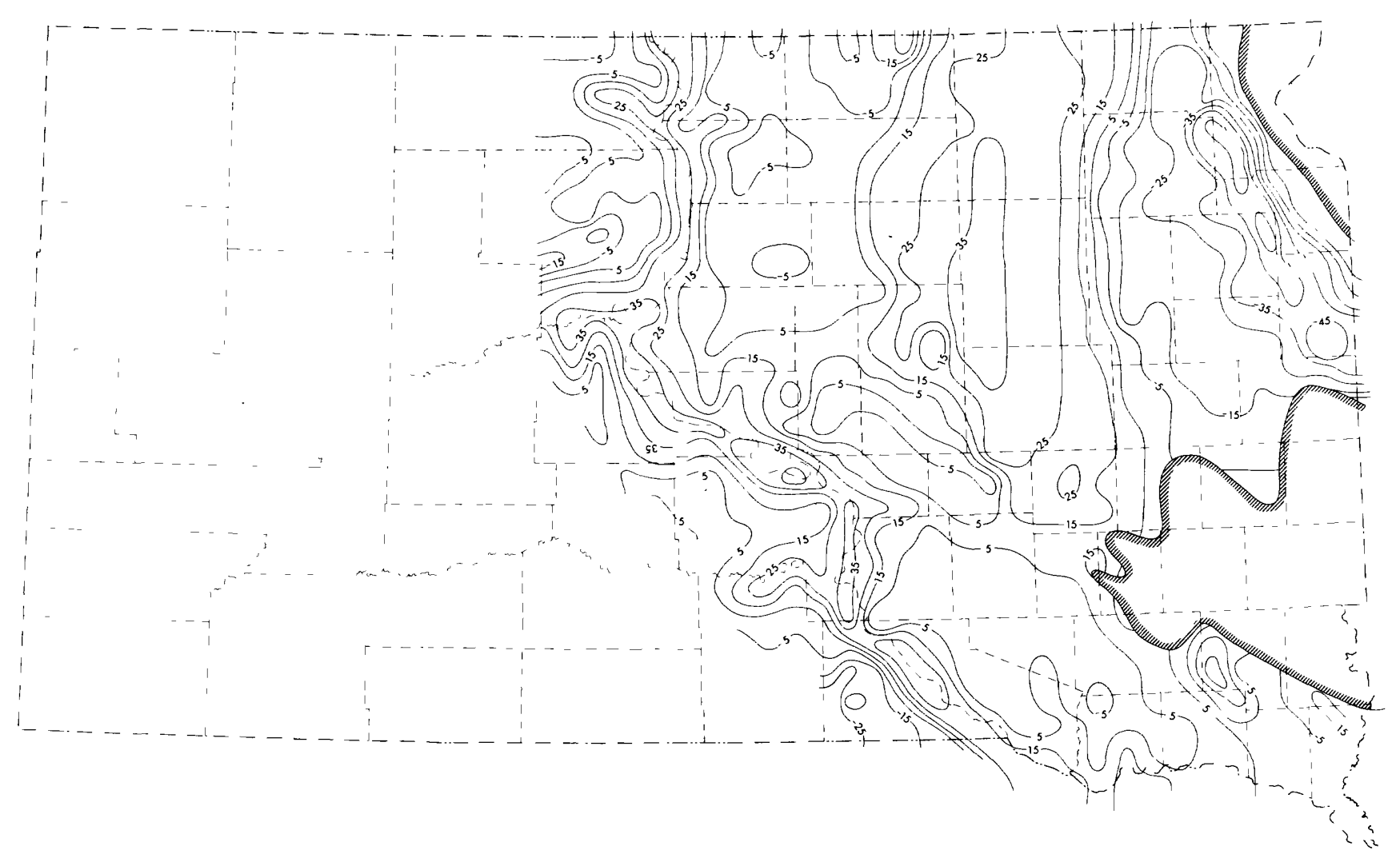

Figure 9. Virgin potentiometric surface for the Dakota aquifer, contours of head above land surface, contour interval is 10 $\mathrm{ft}$ (based on Darton, 1909, Plate XI.) The surface is shown only in the east where the bulk of Darton's data were located. 
For the third model, Trescott's (1975) finitedifference scheme was modified to incorporate these variable well discharges. Also incorporated in the model was an improved algorithm for calculating transient leakage from confining layers (J. V. Tracy, written commun., 1978). This formulation utilizes a convolution of the analytical solution for one-dimensional flow in the confining bed resulting from an arbitrary continuous head change in aquifers on either side. It allows a more accurate computation of leakage due to aquifer head changes than the earlier approximation suggested by Bredehoeft and Pinder (1970).

In the transient simulation, the aquifer storage coefficient and the specific storage of the confining layers were adjusted by trial-and-error until the calculated potentiometric surface was in close agreement with observed conditions in the Dakota. Schoon (1971) presents the potentiometric surface in 1914-15; this is compared with the best calculated surface in figure 14 .

The calculated potentiometric head following development was much more sensitive to the specific storage in the confining layers than to the storage coefficient in the aquifer. When the specific storage in the confining beds was made small, computed drawdowns were too large even when large values for the aquifer storage coefficient were used. Figure 15 shows the computed potentiometric surface after 16 years of simulated development, using the first (single-aquifer) model, for a system in which storage in the confining layer is neglected-"steady" leakage with a confining layer conductivity of $5 \times 10^{-11} \mathrm{ft} / \mathrm{sec}$ is included in this computation. If the assumption that we could neglect the storage within the confining layer were correct, this result should approximate Darton's observations. It clearly does not.

The computed potentiometric surface could be adjusted to good agreement with the observed potentiometric surface only when the specific storage in the confining beds was accounted for. This leads us to conclude that most of the water released from storage in the system since development began has come from the confining beds.

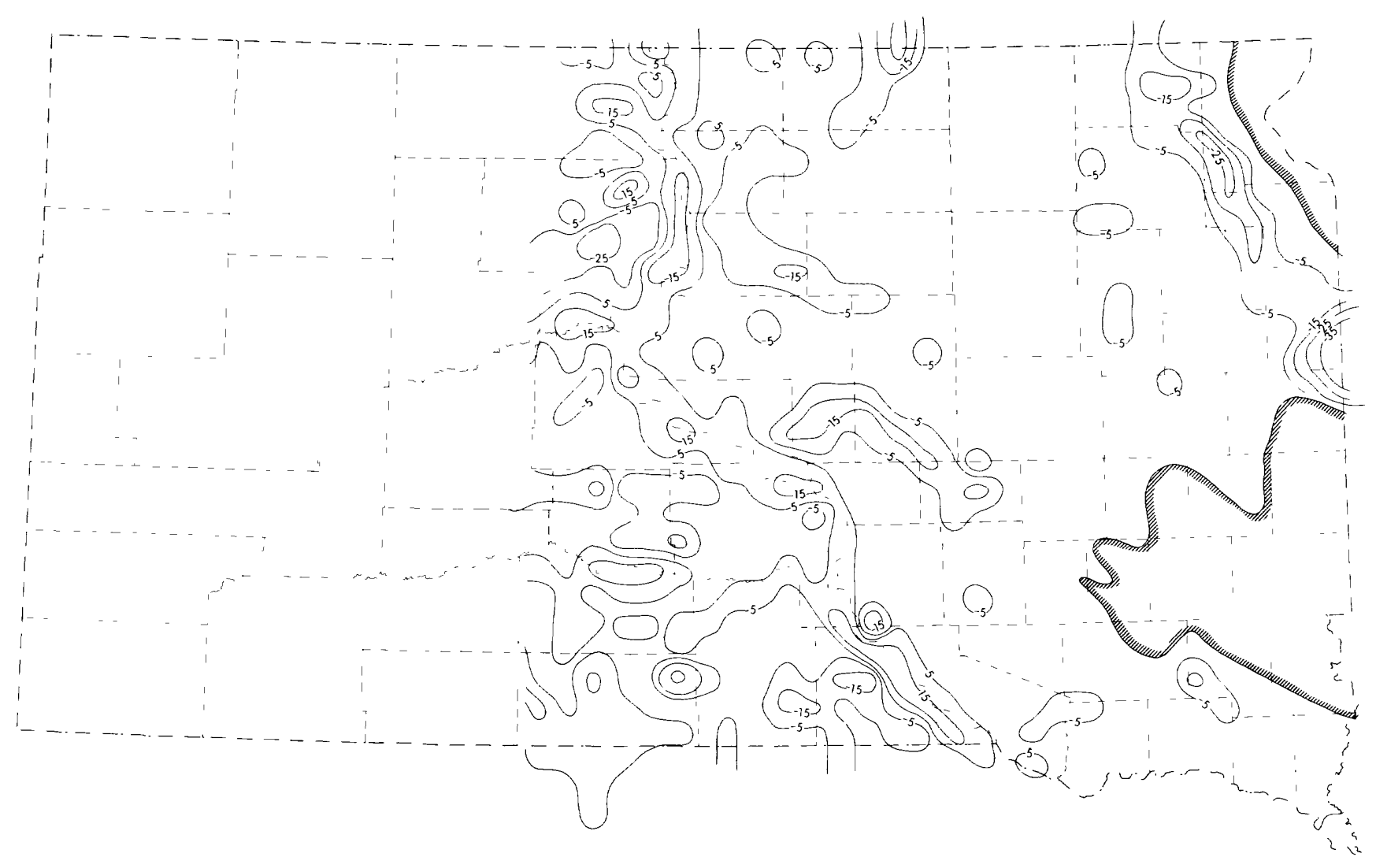

Figure 10. Computed potentiometric surface for the Dakota aquifer, with an assumed hydraulic conductivity for the combined Cretaceous shale confining layer of $5 \times 10^{-9} \mathrm{ft} / \mathrm{sec}$, contours of head above land surface, contour interval is $10 \mathrm{ft}$. Heads are lower than those recorded by Darton (1909) (see figure 9). 


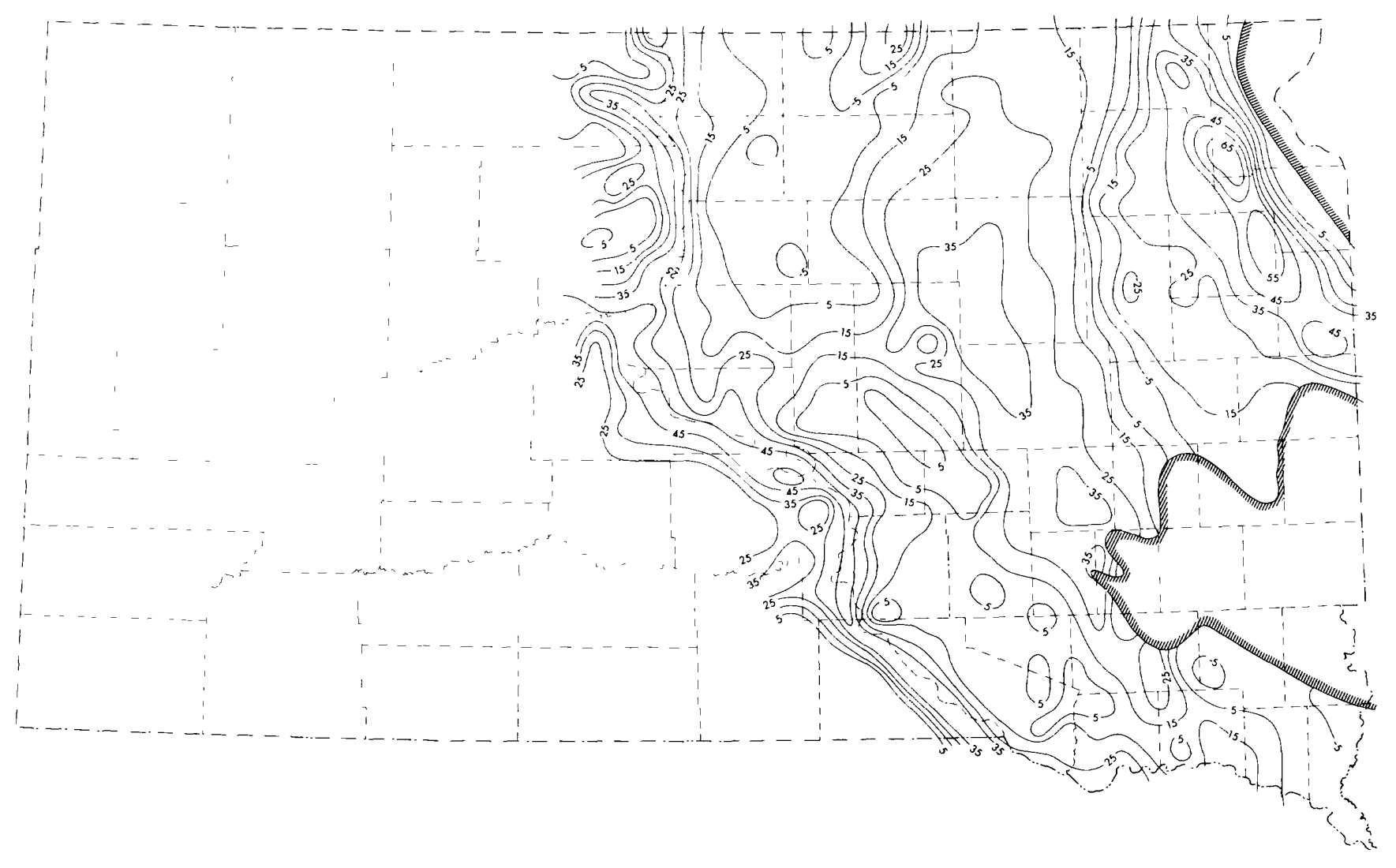

Figure 11. Computed potentiometric surface for the Dakota aquifer, with an assumed hydraulic conductivity for the combined Cretaceous Shale confining layer of $5 \times 10^{-11} \mathrm{ft} / \mathrm{sec}$, contours of head above land surface, contour interval is $\mathbf{1 0} \mathrm{ft}$.

\section{Model of Cretaceous Shale Confining Layer}

The analyses described above treat the Cretaceous shale confining layer as a single homogeneous unit. As seen earlier (fig. 4), this is a considerable simplification. To obtain a better understanding of the Cretaceous shale confining layer, a refined model (fourth model) was used for flow simulations. The Dakota-Newcastle Sandstone, the Greenhorn Limestone, and the Niobrara Formation were treated as aquifers and the intervening shales as confining layers. A limited number of observations of potentiometric head in the Greenhorn Limestone and the Niobrara Formation exist (Steece and Howells, 1965; Stephens, 1967; Koch, 1970; Jorgenson, 1971; U.S. Geological Survey); simulation parameters were adjusted to obtain best agreement with these observations.

Actual adjustment of the parameters was accomplished with a nonlinear least-squares regression technique developed by S. P. Larson (written commun., 1978). The technique iteratively converges on an optimum set of parameters. Optimum parameters are those which minimize $\mathrm{S}^{*}$ :

$$
\mathrm{S}^{*}=\sum_{\mathrm{n}=1}^{\mathrm{N}}\left(\phi_{\mathrm{n}, \mathrm{obs}}-\phi_{\mathrm{n}, \mathrm{calc}}\right)^{2}
$$

where $\phi_{\mathrm{n}, \mathrm{obs}}$ is the observed potentiometric head at the nth node,

$\phi_{\mathrm{n}, \text { calc }}$ is the calculated potentiometric head at the nth node, and

$\mathrm{N}$ is the number of nodes.

As in the previous model analyses, the hydraulic conductivity of the Dakota was assumed to be known. The horizontal and vertical conductivities of the remaining two aquifers and three confining layers were allowed to "float" and assume their optimal values. Some difficulty was encountered with the aquifer conductivities, which tended to assume unrealistically high and low values; this results from the small number of head measurements in the upper two aquifers. The aquifer transmissivities were arbitrarily "frozen," and the confining layer conductivities were allowed to reach their optimum values. The transmissivity of the Niobrara and the vertical conductivity of the Pierre were found to be highly correlated. This means that, in the model, there was lit- 


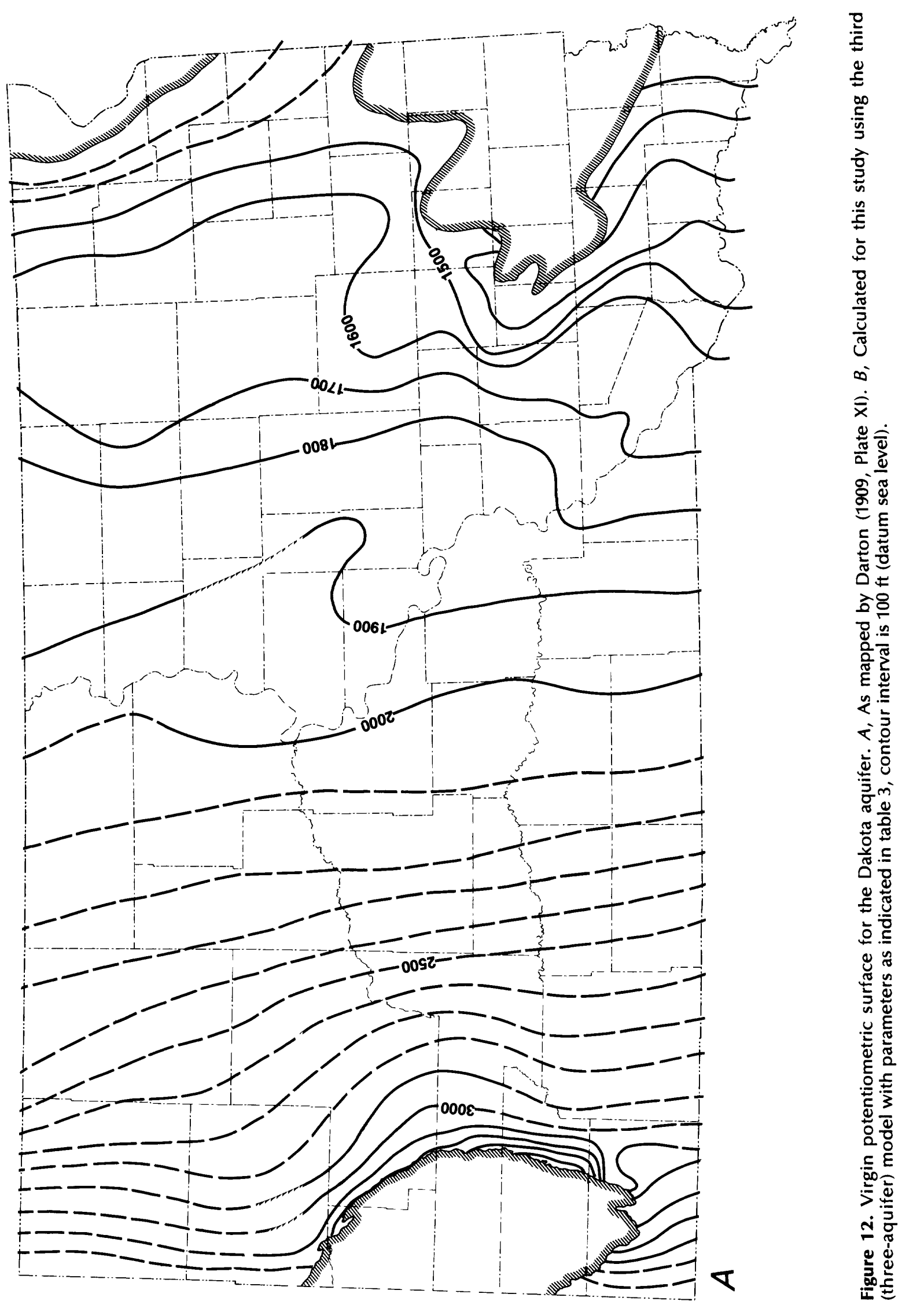




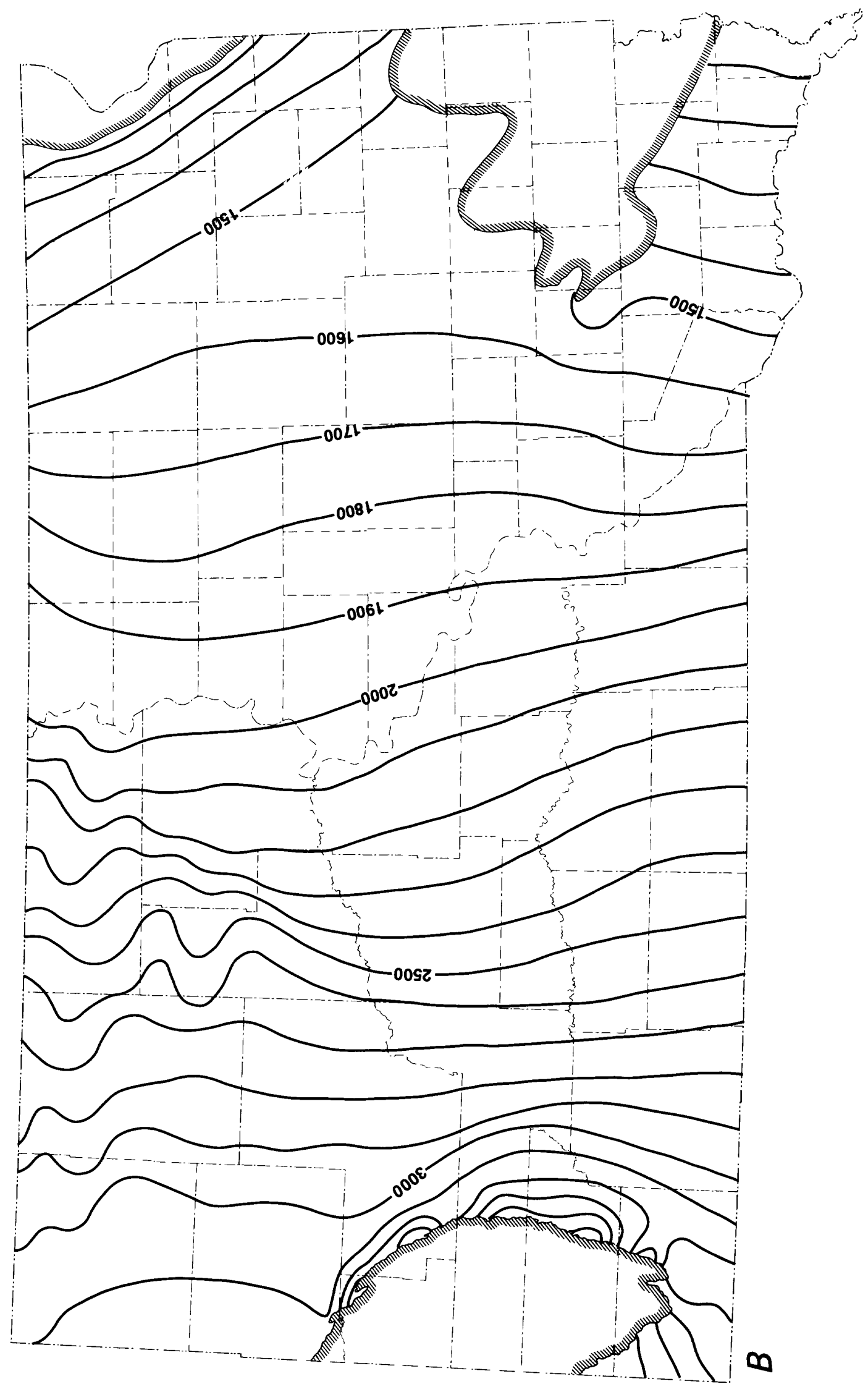

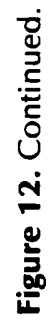


tle difference in the computed heads when both transmissivity in the Niobrara and conductivity in the Pierre were increased or decreased by the same factor. Because the transmissivity in the Niobrara is somewhat uncertain, the same is true of vertical conductivity in the Pierre.

\section{Simulation Parameters}

The numerical analyses described above allowed us to estimate the verticle hydraulic conductivity in the confining layers of the aquifer system. The "best" set of parameter values from the various models are reported in table 3 . In considering these values it is well to recall the assumptions and limitations of the analyses. All the models simplify the geologic and hydrologic system to a greater or lesser extent. Although the thickness of each unit varied, the hydraulic conductivity and specific storage of each unit was assumed to be constant. This is a simplification of complex stratigraphy. For example, Schoon (1971) presents evidence suggesting that the Newcastle Sandstone, the western Dakota equivalent, is actually several discontinuous stringers. The models, however, treat the Newcastle as a single thin sheet. West of the Missouri Trench, simulations using each model calculate potentiometric heads higher than those indicated by Darton. Although we have earlier argued for this hydraulic continuity, it is quite possible that the discontinuity of the sandstones suggested by Schoon (1971) is not sufficiently accounted for in the models; were the effective transmissivity of the Newcastle reduced to account for the discountinuity of the sands, the heads might be closer to those suggested by Darton.

All the models yield values in reasonably close agreement for the vertical conductivity of Cretaceous shale confining layer (table 3 ). The vertical hydraulic conductivity is well defined because potentiometric head in the Dakota is quite sensitive to its value. This estimate of vertical hydraulic conductivity is as good as our knowledge of the hydraulic conductivity of the Dakota aquifer.

Obtaining better values of certain parameters using the Cretaceous shale confining layer model was made difficult by the small number and limited geographic distribution of observations of potentiome-

Table 3. "Best-fit" parameters used in various model analyses

$\left[\mathrm{K}_{\mathrm{z}}^{\prime}\right.$, confining layer vertical hydraulic conductivity ( $\left.\mathrm{ft} / \mathrm{sec}\right) ; \mathrm{K}_{\mathrm{x}, \mathrm{y}^{\prime}}$, aquifer horizontal hydraulic conductivity (ft/sec); $\mathrm{S}_{\mathrm{s}^{\prime}}$, confining layer specific storage $\left(\mathrm{ft}^{-1}\right)$; and $\mathrm{S}$, aquifer storage coefficient (dimensionless)]

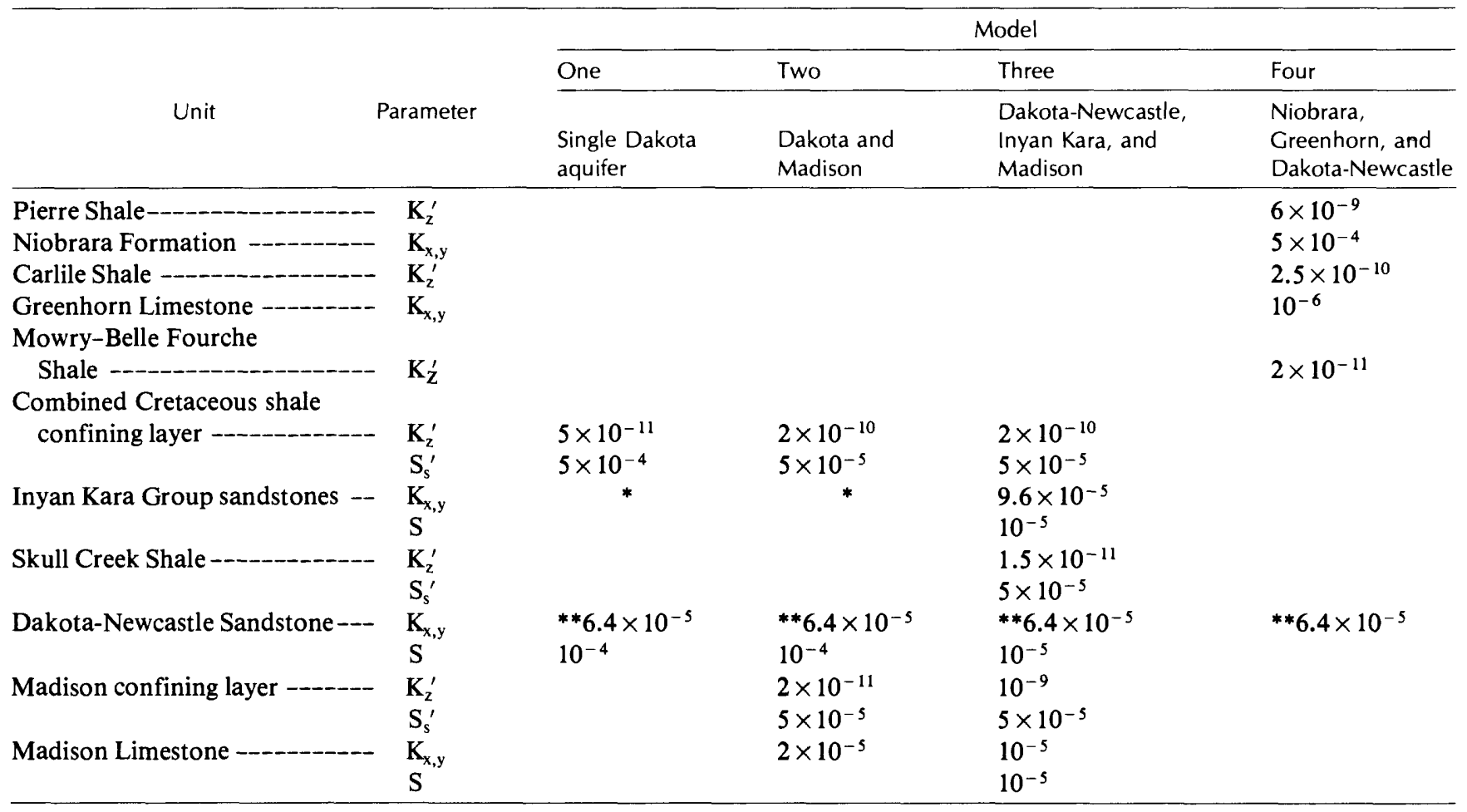

* Dakota and Inyan Kara modeled as single aquifer.

** $\mathrm{K}_{\mathrm{x}, \mathrm{y}}$ of Dakota-Newcastle Sandstone was treated as a "known" quantity. 
tric head in the Niobrara and Greenhorn aquifers. This limited set of observations produces a tendency for the computed Greenhorn and Niobrara hydraulic conductivities to become unrealistic when using the nonlinear least-squares regression method of parameter estimation. It also yields poorer estimates of the vertical conductivities in the Pierre and Carlile Shales than for the lower Mowry-Belle Fourche Shale. As measured by the expected error, the Pierre and Carlile values are plus or minus 95 and 98 percent, respectively; the Mowry-Belle Fourche value is plus or minus only 24 percent.

It is of interest to note the trend of decreasing hydraulic conductivity with depth of burial in the Cretaceous shale confining layer (table 3 ). If the Skull Creek Shale below the Newcastle Sandstone is included, the conductivity appears to approach a minimum value of approximately $10^{-11} \mathrm{ft} / \mathrm{sec}$.

In summary, the gross vertical hydraulic conductivity of the combined Cretaceous shale confining layer is well defined. However, the layer contains several shale units as well as two minor, but extensive, aquifers. There is insufficient information to define the vertical conductivities of the individual shales with precision, but the analysis indicates, as we might expect, a decrease in hydraulic conductivity with depth of burial.

\section{Total Flow}

From the numerical analysis, one can compute the total flow through each element of the system. We have made these computations for the third (three-aquifer) model. The results of summing all the flow, both in and out of the boundaries and through the confining layers, are shown in figure 16. The balance indicates that the total steady-state flow through the entire system in South Dakota was quite small, on the order of 100 $\mathrm{ft}^{3} / \mathrm{sec}$. Furthermore, most of the recharge and discharge of the Dakota aquifer occurred as leakage through the confining layers, especially through the overlying Cretaceous shale confining layer.

We have chosen to treat the Paleozoic rocks beneath the Madison as impermeable in our models, thus no flow in these units is represented in figure 16. Flow occurring in these rocks would have been lumped with flow in the Madison in our analysis and thus cannot be distinguished.

The computed steady-state areal distribution of leakage between the Dakota aquifer and the surface through the Cretaceous shale confining layer is shown in figure 17. The rates of leakage vary from zero to approximately $\pm 10 \times 10^{-11} \mathrm{ft} / \mathrm{sec}$. This is equivalent to a maximum rate of $\pm 0.04 \mathrm{in} / \mathrm{yr}$. These are small quantities of leakage; however, when one considers the large areas over which they occur, they become significant.

\section{CRETACEOUS SHALE CONFINING LAYER: IN SITU AND LABORATORY TESTS}

A number of tests have been conducted both in the field and in the laboratory in an effort to investigate further the hydraulic conductivity of the shale confining layers.

\section{Pumping Test at Wall, South Dakota}

Gries and others (1976) describe one of the few carefully conducted pumping tests in the Dakota Sandstone. Three municipal wells in Wall, South Dakota, were utilized; one was pumped, and the others were used as observation wells. As pointed out earlier, Gries and others analyzed the results using the nonleaky solution of Theis (1935). However, the data can also be fitted to the modified solution of Hantush (1960), which includes leakage from confining layers with storage (fig. 18).

The modified Hantush solution yields a product of vertical hydraulic conductivity, $\mathrm{K}_{\mathrm{z}}^{\prime}$, and specific storage, $\mathrm{S}_{s}^{\prime}$, for the confining layer. The data from both observation wells fit the modified Hantush solution and yield two different values for the product:

1. $\mathrm{K}_{\mathrm{Z}}^{\prime} \mathrm{S}_{\mathrm{S}}^{\prime}=2.8 \times 10^{-15} \mathrm{sec}^{-1}$ and

2. $\mathrm{K}_{\mathrm{z}}^{\prime} \mathrm{S}_{\mathrm{s}}^{\prime}=1.3 \times 10^{-15} \mathrm{sec}^{-1}$.

The product cannot be factored using information from the test. However, if we use the simulation-derived estimate for $\mathrm{S}_{\mathrm{s}}$ of $5 \times 10^{-5} \mathrm{ft}^{-1}$, we obtain two values of vertical hydraulic conductivity:

1. $\mathbf{K}_{\mathrm{z}}^{\prime}=5.7 \times 10^{-11} \mathrm{ft} / \mathrm{sec}$ and

2. $\mathrm{K}_{\mathrm{z}}^{\prime}=2.7 \times 10^{-11} \mathrm{ft} / \mathrm{sec}$.

These values are close to those estimated for the MowryBelle Fourche and Skull Creek Shales in the numerical flow simulations.

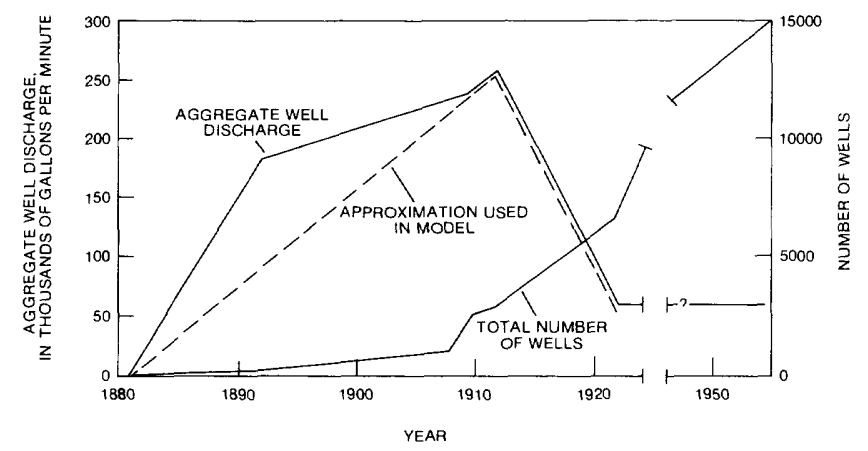

Figure 13. Well discharge and number of wells, Dakota aquifer in South Dakota. 


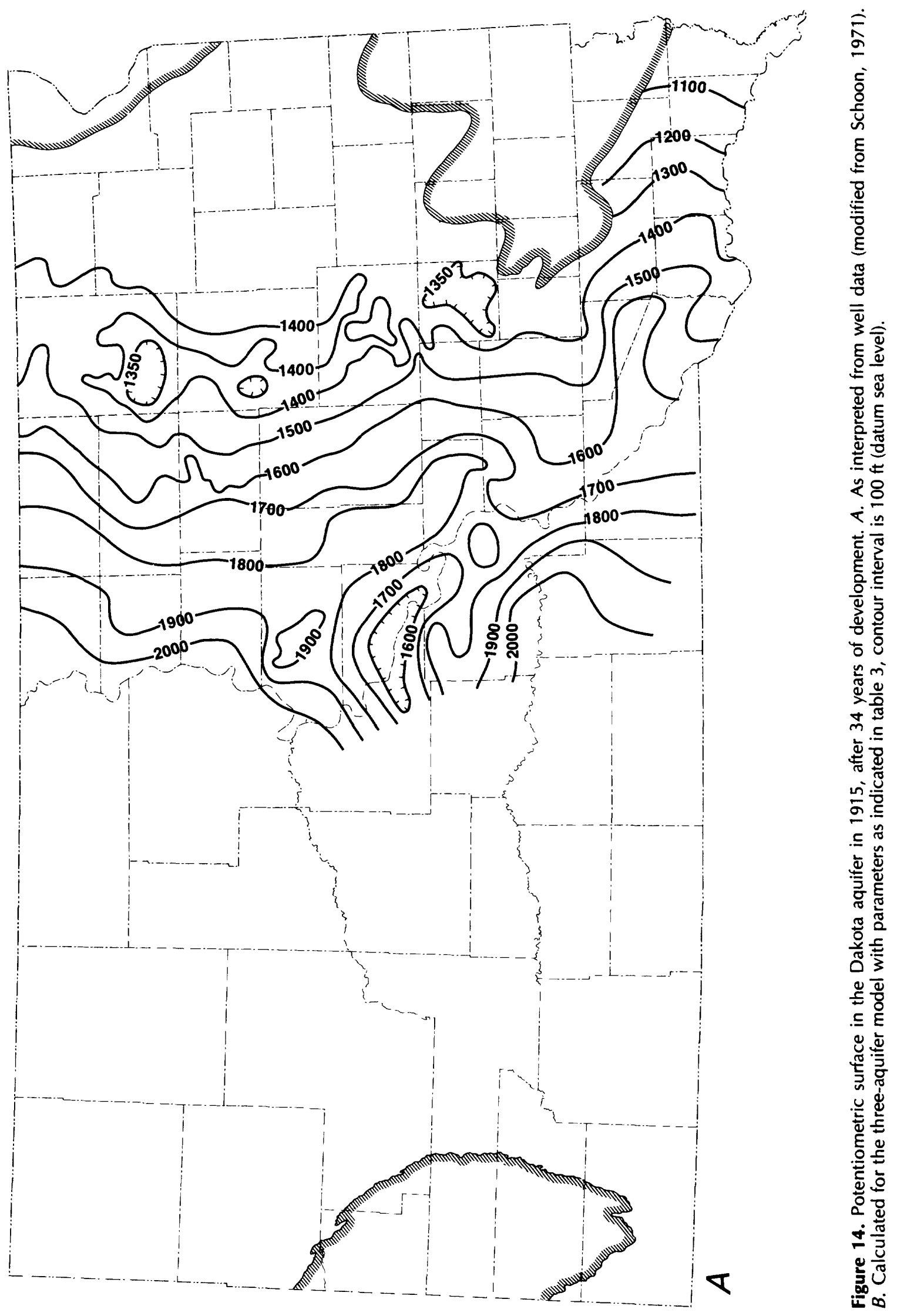




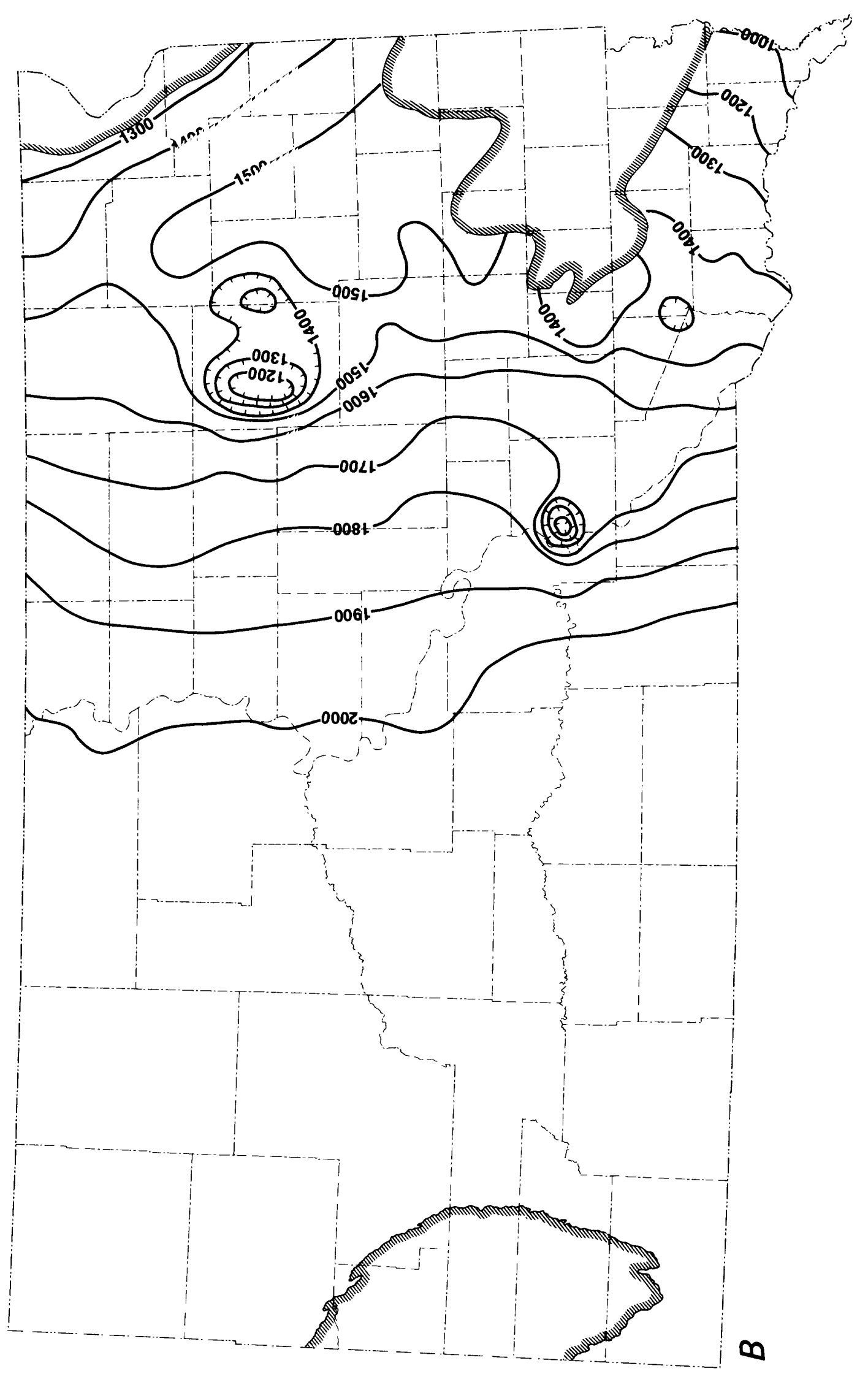

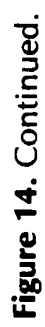




$$
\frac{x^{2} 5}{5}
$$




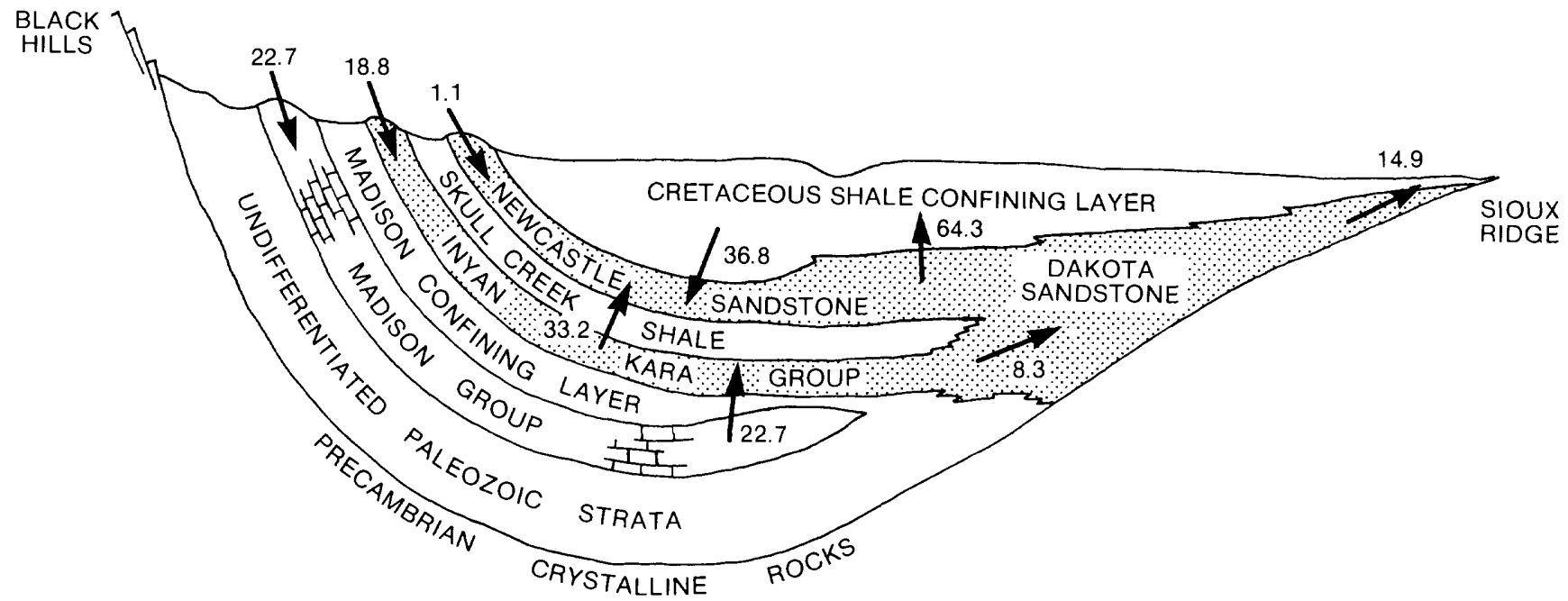

Figure 16. Computed virgin, or steady flow, through the major elements of the aquifer system in South Dakota. Flows are summed over the entire model area; units are cubic feet per second.

\section{Slug Tests in the Pierre Shale}

Three modified slug tests (Bredehoeft and Papadopulos, 1980; Neuzil, 1982) were conducted for this investigation in a borehole located at site $\mathrm{A}$ in figure 19. This type of test is well suited for making in situ measurements of hydraulic properties in very low permeability rocks. A packer was set at $105 \mathrm{ft}$, and the interval from the packer to the bottom of the hole was tested. Upon completion of the first test, the packer was lowered to $210 \mathrm{ft}$ and reset, and the lower portion of the hole was retested. A third test was conducted in the same manner with the packer set at $378 \mathrm{ft}$.

The test setup is shown schematically in figure 20 . For redundancy, two separate transducers were used to record the pressure decay. An example of the test results, plotted as dimensionless head decline versus time, is shown matched to a type curve in figure 21 .

Successively shorter portions of the hole were tested; transmissivities of three separate portions of the borehole were calculated. The results of these calculations are summarized in figure 22 . The data from the tests are internally consistent in that, as smaller portions of the section were tested, smaller transmissivity values were calculated. The calculated hydraulic conductivity also decreases with depth.

Bredehoeft and Papadopulos (1980) point out that the modified slug test is not without potential sources of error. During the test, very small volumes of water flow from the borehole into the rock. The possibility exists that sufficient leakage occurs through joints and con- nections in the test apparatus or past the packer to produce an erroneous pressure decay. Leakage from the piping is particularly hard to rule out. If leakage occurs, the computed conductivity will be larger than the true conductivity of the rock.

Some evidence exists that leakage did occur in the system and that the calculated conductivities are too large. Inflation of the packers causes a small pressure rise which itself constitutes a slug test. In instances where the decay of these small pressure pulses was monitored, their decline differed from that of the full slug; the decay in this instance was slower. This suggests that the higher pressure differences associated with the full slug may have caused leakage around the packer. The actual conductivity of the rock may be lower than we have calculated.

\section{Laboratory Pulse Tests}

The usual laboratory hydraulic conductivity tests require that steady flow be established through the sample. At low values of conductivity, a long period of time is necessary to establish steady flow in a sample in which the compressive storage is significant. In addition, unless unrealistically large hydraulic gradients across the sample are used, the flow rates are small and difficult to measure. For these reasons, various investigators have attempted to utilize transient laboratory tests for low-permeability rock. An analytical solution and test methodology has been presented for a transient pulse 


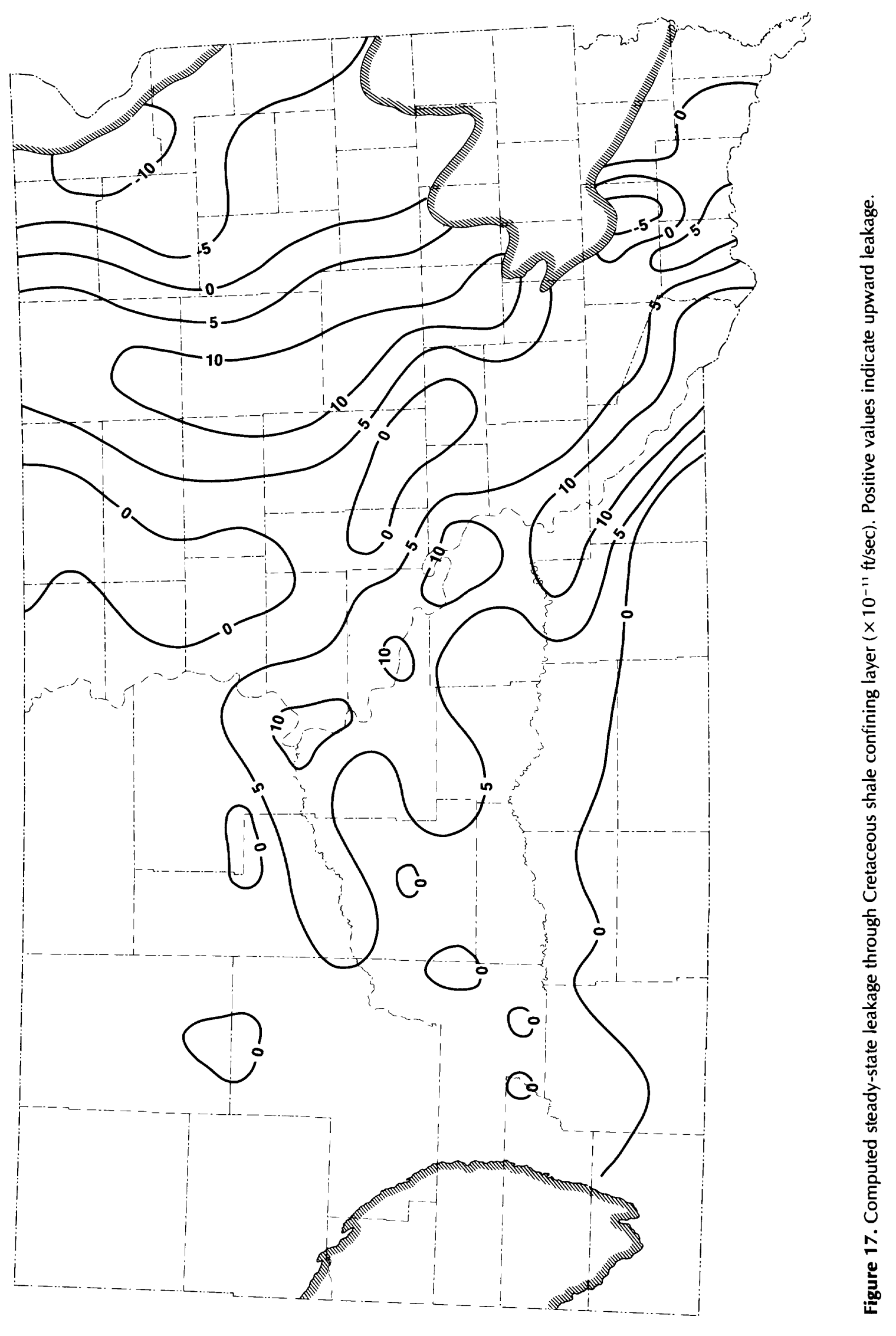




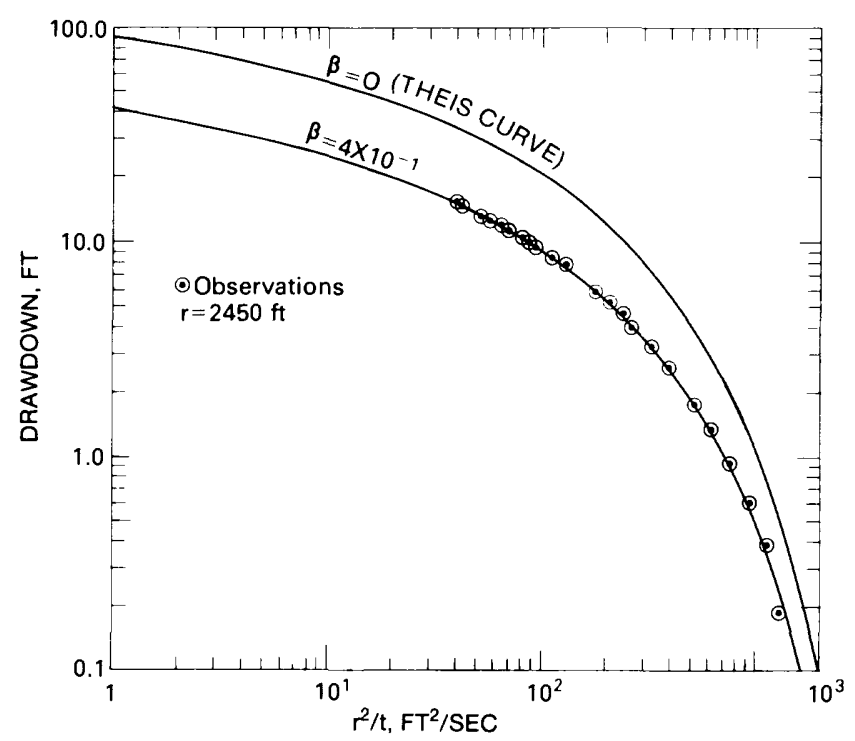

Figure 18. Drawdown data from one observation well collected during the pumping test at Wall, South Dakota, conducted by Gries and others (1976). The data are plotted to show the fit to the modified leaky-aquifer-type curve.

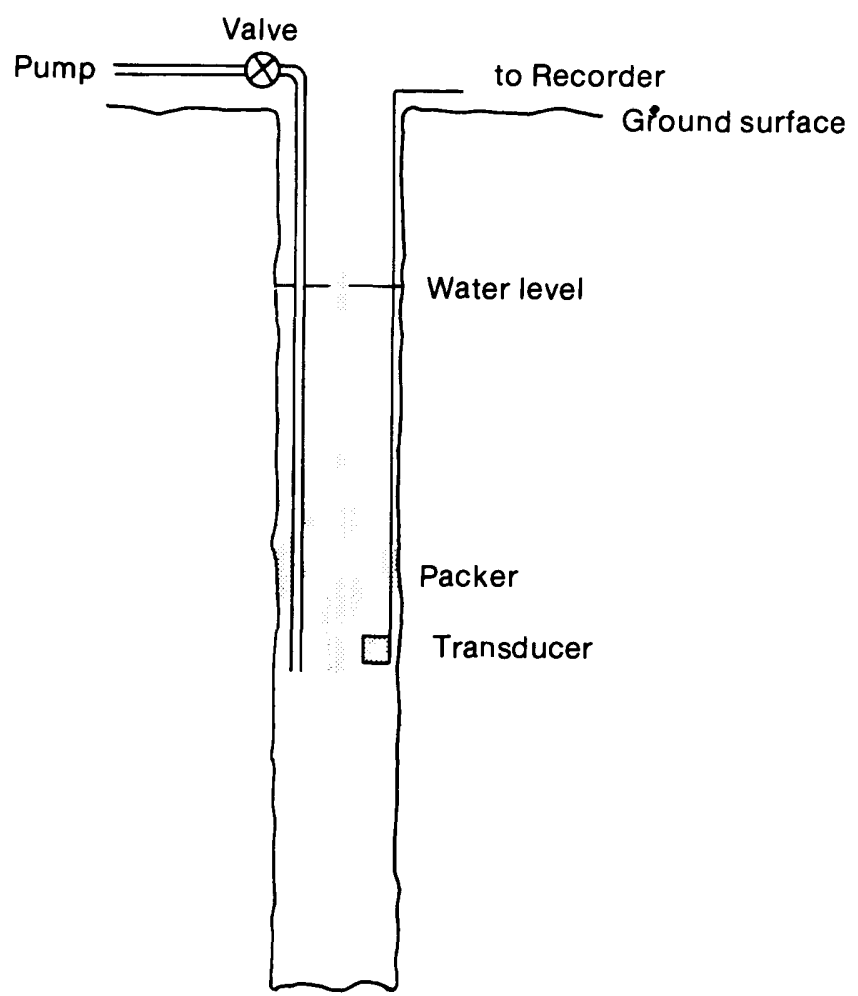

Figure 20. Schematic diagram showing the test setup used for conducting the modified slug tests.

test in the laboratory in which the upstream and downstream reservoir volumes are arbitrary, which is the most general situation (Hsieh and others, 1981; Neuzil and others, 1981). The analysis has been applied to data from pulse tests conducted on core samples of the Pierre Shale from sites B and C in figure 19. The test apparatus was developed and built by Terratek, Inc., of Salt Lake City, Utah. The Terratek apparatus, because it has been recently built, has been used for only a limited number of tests; hydraulic properties of the shale determined in these tests are presented in table 4 .

\section{Laboratory Consolidation Tests}

Consolidation tests are a well-established technique in soil mechanics for analyzing the deformation of saturated porous media under an applied load (see, for example, Scott, 1963). The theory of consolidation was developed by Karl Terzaghi in a series of articles in the 1920's (Casagrande, 1960). Assuming Terzaghi's theory applies, the deformation with time of a sample under a load can be used to calculate the hydraulic conductivity and specific storage of the sample, even when the conductivity is quite small.
Figure 19. Locations of test hole sites for this investigation. Facies boundaries adapted from Reeside (1944). Modified slug tests were conducted at site $A$. Cores for laboratory hydraulic conductivity determinations were obtained at sites $A$, $B$, and $C$. 


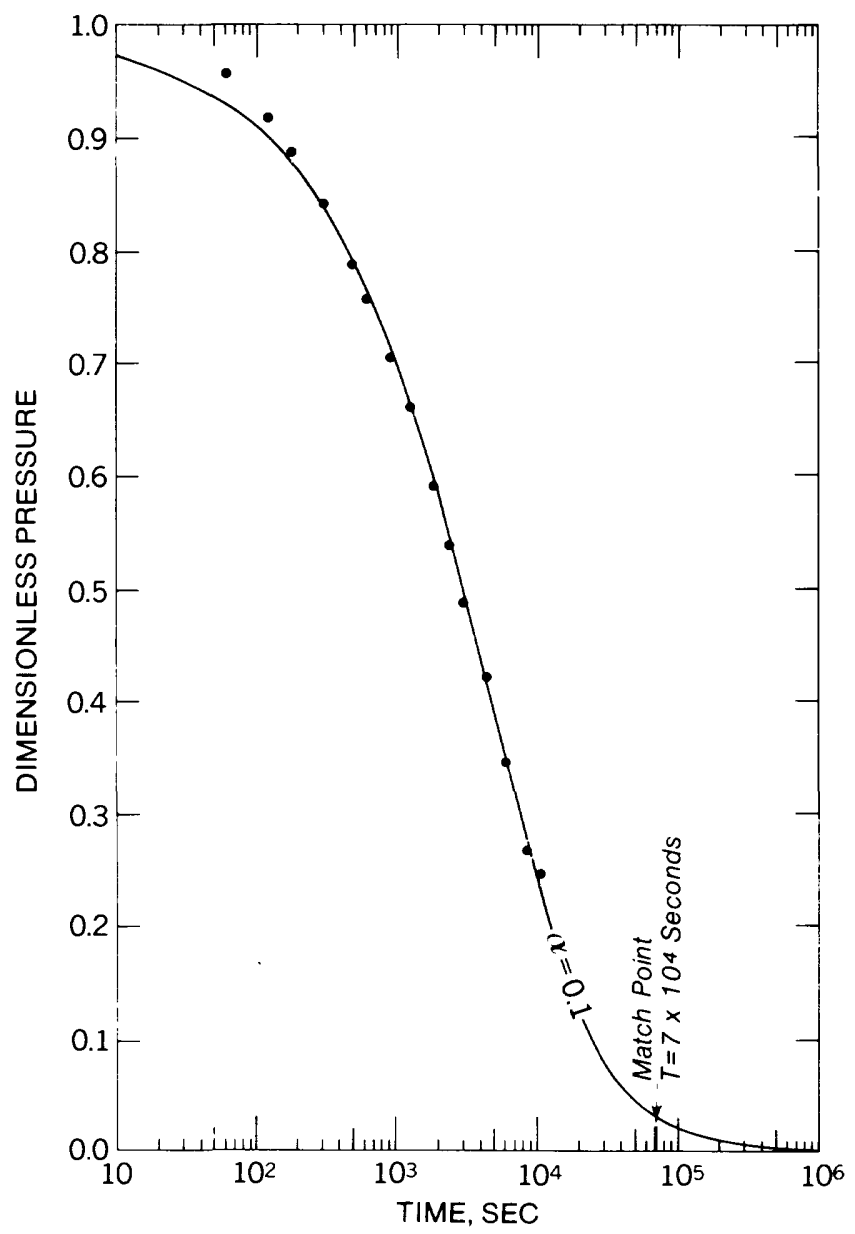

Figure 21. Pressure decay data for a modified slug test in the Pierre Shale matched to a type curve.

Consolidation tests were conducted by the U.S. Army Corps of Engineers at their soil laboratory in Omaha, Nebraska, on core samples of the Pierre Shale from two sites (locations A and B on fig. 19). The hydraulic properties we have calculated from these tests are summarized in table 5.

\section{DISCUSSION OF SHALE HYDRAULIC PROPERTIES}

\section{Hydraulic Conductivity}

Three scales of hydraulic conductivity information pertaining to the Pierre Shale were obtained in this study. Values were obtained from (1) numerical simulation of regional aquifer flow, (2) in situ hydraulic testing, and (3) laboratory testing. The three sources provide estimates of hydraulic conductivity at three very different scales. Discrepancies in conductivity not apparent at one scale are apparent when results at different scales are compared.

The results of our various conductivity determinations for the Cretaceous shale confining layer are summarized in figure 23; hydraulic conductivity is plotted as a function of depth of burial, or equivalent effective stress. For the laboratory data, the vertical scale represents the effective stress at which the test was conducted and generally is not indicative of the depth from which the sample was collected. Conversely, the actual mean depths are shown in the plotting of the in situ and regional data.

All of the laboratory and slug test results fall in the range of $10^{-11}$ to $10^{-14} \mathrm{ft} / \mathrm{sec}$. There is a strong tendency for hydraulic conductivity to decrease with depth of burial. This is illustrated by straight lines which have been fit to the consolidation data alone and to the consolidation, transient pulse, and slug test data together using the least-squares method.

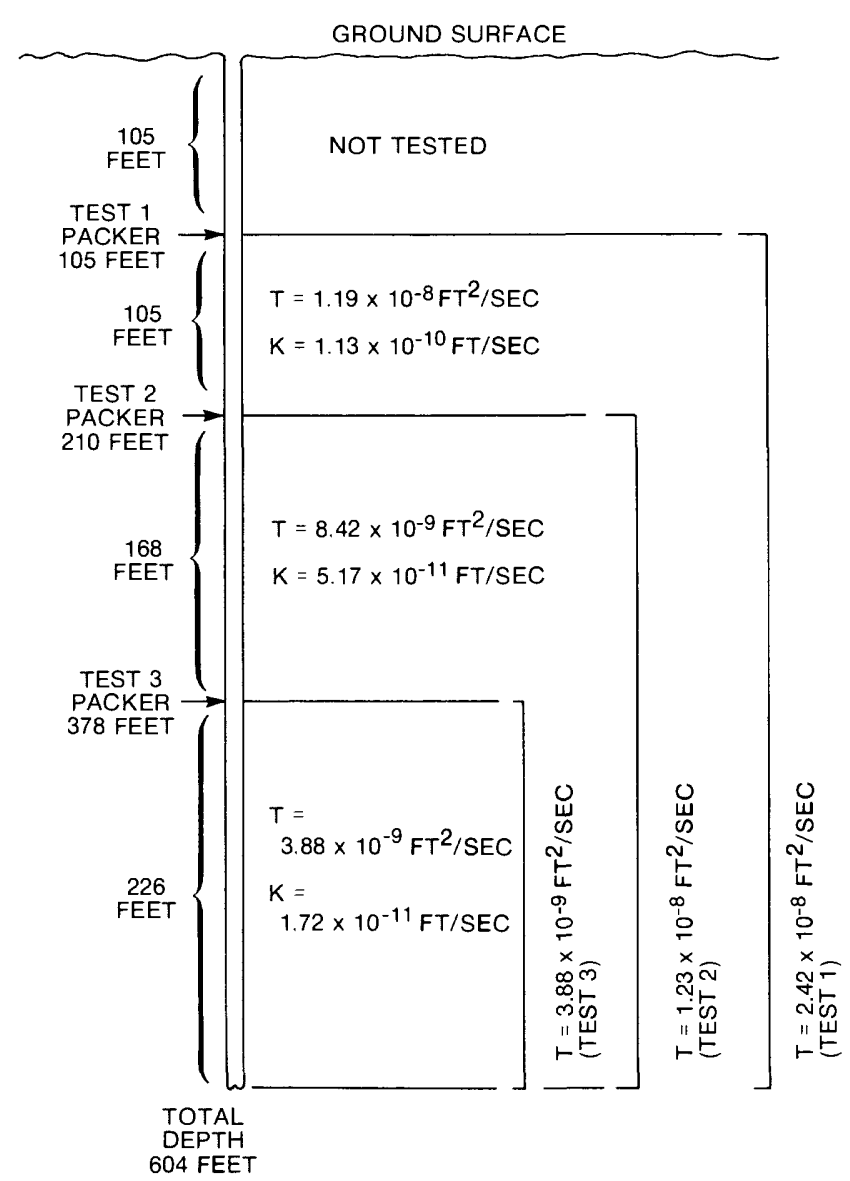

Figure 22. Hydraulic conductivity of the Pierre Shale calculated from results of modified slug tests in borehole at site $A$ (see fig. 19). 
The hydraulic conductivities obtained from the slug tests are probably more consistent with the consolidation data least-squares line values than shown in figure 23 because (1) as noted earlier, leakage during the test may have caused calculated values which are too large and (2) the slug tests measured horizontal hydraulic conductivity, whereas the other data shown in figure 23 are for vertical hydraulic conductivity. In sedimentary rocks, the hydraulic conductivity is generally greatest parallel to the bedding.

A least-squares line has also been fitted to the estimates of hydraulic conductivity obtained using the regional flow simulations. The regional values quite clearly indicate a different trend than the small-scale laboratory and intermediate-scale slug tests; the estimates from the regional flow simulations are consistently larger, generally by one to three orders of magnitude.

This discrepancy between the small- and largescale results suggests that the confining layer is probably fractured. The leakage observed on a regional scale could occur largely in the fractures; however, the hydraulic conductivities measured in the laboratory and the slug tests reflect the properties of the intact shale between fractures.

The pumping test at Wall yielded values comparable with those of the regional model analysis (fig. 23). This indicates that the pumping test may have been influenced by leakage from fractures in the confining layer. During the 44-hr duration of the test, the cone of depression spread out to a radius of $6 \mathrm{mi}$ from the pumped well, suggesting that the fracture spacing in the confining layer is on the order of miles or less.

The scatter present in the laboratory data probably results from measurement error, not lithologic differences in the samples. Small hydraulic conductivities are difficult to measure, and resolution of such small values to significantly better than order-of-magnitude may not be possible.

Table 4. Summary of laboratory transient pulse test results for the Pierre Shale

[Locations B and C refer to fig. 19]

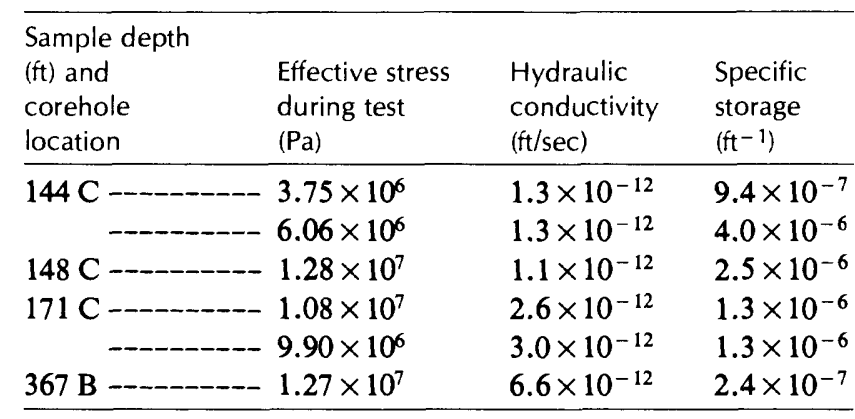

Table 5. Summary of laboratory consolidation test results for the Pierre Shale

[Locations A and B refer to fig. 19]

\begin{tabular}{|c|c|c|c|}
\hline $\begin{array}{l}\text { Sample depth } \\
\text { (ft) and } \\
\text { corehole } \\
\text { location }\end{array}$ & $\begin{array}{l}\text { Average } \\
\text { effective stress } \\
\text { during test }(\mathrm{Pa})\end{array}$ & $\begin{array}{l}\text { Hydraulic } \\
\text { conductivity } \\
(\mathrm{ft} / \mathrm{sec})\end{array}$ & $\begin{array}{l}\text { Specific } \\
\text { storage } \\
\left(\mathrm{ft}^{-1}\right)\end{array}$ \\
\hline \multirow[t]{6}{*}{108 B - } & $1.13 \times 10^{6}$ & $2.3 \times 10^{-12}$ & $2.0 \times 10^{-5}$ \\
\hline & $2.29 \times 10^{6}$ & $7.2 \times 10^{-13}$ & $1.4 \times 10^{-5}$ \\
\hline & $4.64 \times 10^{6}$ & $5.9 \times 10^{-13}$ & $1.3 \times 10^{-5}$ \\
\hline & $9.28 \times 10^{6}$ & $3.3 \times 10^{-13}$ & $1.3 \times 10^{-5}$ \\
\hline & $1.59 \times 10^{7}$ & $1.3 \times 10^{-13}$ & $1.3 \times 10^{-5}$ \\
\hline & $2.48 \times 10^{7}$ & $1.2 \times 10^{-13}$ & $1.3 \times 10^{-5}$ \\
\hline \multirow[t]{6}{*}{400 B - } & $1.16 \times 10^{6}$ & $1.4 \times 10^{-12}$ & $1.6 \times 10^{-5}$ \\
\hline & $2.30 \times 10^{6}$ & $6.2 \times 10^{-13}$ & $1.5 \times 10^{-5}$ \\
\hline & $4.60 \times 10^{6}$ & $4.3 \times 10^{-13}$ & $1.4 \times 10^{-5}$ \\
\hline & $9.21 \times 10^{6}$ & $1.8 \times 10^{-13}$ & $1.3 \times 10^{-5}$ \\
\hline & $1.57 \times 10^{7}$ & $6.9 \times 10^{-14}$ & $1.1 \times 10^{-5}$ \\
\hline & $2.47 \times 10^{7}$ & $6.2 \times 10^{-14}$ & $8.5 \times 10^{-6}$ \\
\hline \multirow[t]{5}{*}{$233 \mathrm{~A}$} & $2.27 \times 10^{6}$ & $2.0 \times 10^{-12}$ & $8.2 \times 10^{-6}$ \\
\hline & $4.54 \times 10^{6}$ & $1.1 \times 10^{-12}$ & $8.2 \times 10^{-6}$ \\
\hline & $9.09 \times 10^{6}$ & $6.2 \times 10^{-13}$ & $8.2 \times 10^{-6}$ \\
\hline & $1.55 \times 10^{7}$ & $1.8 \times 10^{-13}$ & $8.5 \times 10^{-6}$ \\
\hline & $2.46 \times 10^{7}$ & $8.9 \times 10^{-14}$ & $8.8 \times 10^{-6}$ \\
\hline \multirow[t]{5}{*}{$482 \mathrm{~A}$} & $2.30 \times 10^{6}$ & $5.3 \times 10^{-13}$ & $4.0 \times 10^{-6}$ \\
\hline & $4.60 \times 10^{6}$ & $3.2 \times 10^{-13}$ & $4.0 \times 10^{-6}$ \\
\hline & $9.21 \times 10^{6}$ & $6.6 \times 10^{-13}$ & $4.0 \times 10^{-6}$ \\
\hline & $1.57 \times 10^{7}$ & $1.2 \times 10^{-13}$ & $4.0 \times 10^{-6}$ \\
\hline & $2.47 \times 10^{7}$ & $4.3 \times 10^{-13}$ & $4.0 \times 10^{-6}$ \\
\hline \multirow[t]{5}{*}{$102 \mathrm{~A}-$} & $2.31 \times 10^{6}$ & $4.6 \times 10^{-12}$ & $1.2 \times 10^{-5}$ \\
\hline & $4.64 \times 10^{6}$ & $7.2 \times 10^{-12}$ & $1.2 \times 10^{-5}$ \\
\hline & $9.37 \times 10^{6}$ & $1.4 \times 10^{-12}$ & $1.3 \times 10^{-5}$ \\
\hline & $1.60 \times 10^{7}$ & $3.6 \times 10^{-13}$ & $1.3 \times 10^{-5}$ \\
\hline & $2.48 \times 10^{7}$ & $3.0 \times 10^{-13}$ & $1.4 \times 10^{-5}$ \\
\hline \multirow[t]{5}{*}{450 B - - } & $2.27 \times 10^{6}$ & $3.1 \times 10^{-12}$ & $9.4 \times 10^{-6}$ \\
\hline & $4.54 \times 10^{6}$ & $2.7 \times 10^{-12}$ & $9.8 \times 10^{-6}$ \\
\hline & $9.09 \times 10^{6}$ & $6.9 \times 10^{-13}$ & $1.0 \times 10^{-5}$ \\
\hline & $1.55 \times 10^{7}$ & $3.1 \times 10^{-13}$ & $1.0 \times 10^{-5}$ \\
\hline & $2.46 \times 10^{7}$ & $2.3 \times 10^{-13}$ & $1.1 \times 10^{-5}$ \\
\hline \multirow[t]{5}{*}{$125 \mathrm{~A}---$} & $2.32 \times 10^{6}$ & $6.9 \times 10^{-13}$ & $1.1 \times 10^{-5}$ \\
\hline & $4.64 \times 10^{6}$ & $4.3 \times 10^{-13}$ & $1.1 \times 10^{-5}$ \\
\hline & $9.28 \times 10^{6}$ & $3.2 \times 10^{-13}$ & $1.2 \times 10^{-5}$ \\
\hline & $1.58 \times 10^{7}$ & $1.3 \times 10^{-13}$ & $1.3 \times 10^{-5}$ \\
\hline & $2.47 \times 10^{7}$ & $9.2 \times 10^{-14}$ & $1.3 \times 10^{-5}$ \\
\hline \multirow[t]{7}{*}{$364 \mathrm{~A} \cdots$} & $5.83 \times 10^{5}$ & $1.6 \times 10^{-11}$ & $1.4 \times 10^{-5}$ \\
\hline & $1.17 \times 10^{6}$ & $5.3 \times 10^{-12}$ & $1.4 \times 10^{-5}$ \\
\hline & $2.32 \times 10^{6}$ & $2.0 \times 10^{-12}$ & $7.6 \times 10^{-6}$ \\
\hline & $4.64 \times 10^{6}$ & $1.3 \times 10^{-12}$ & $7.6 \times 10^{-6}$ \\
\hline & $9.28 \times 10^{6}$ & $5.6 \times 10^{-13}$ & $7.9 \times 10^{-6}$ \\
\hline & $1.59 \times 10^{7}$ & $9.5 \times 10^{-14}$ & $7.9 \times 10^{-6}$ \\
\hline & $2.48 \times 10^{7}$ & $8.2 \times 10^{-14}$ & $8.2 \times 10^{-6}$ \\
\hline
\end{tabular}

\section{Specific Storage}

The specific storage of the confining layer was also determined by all the methods of analysis; these results are summarized in figure 24 . As with the hydraulic conductivity data, the results are plotted against effec- 


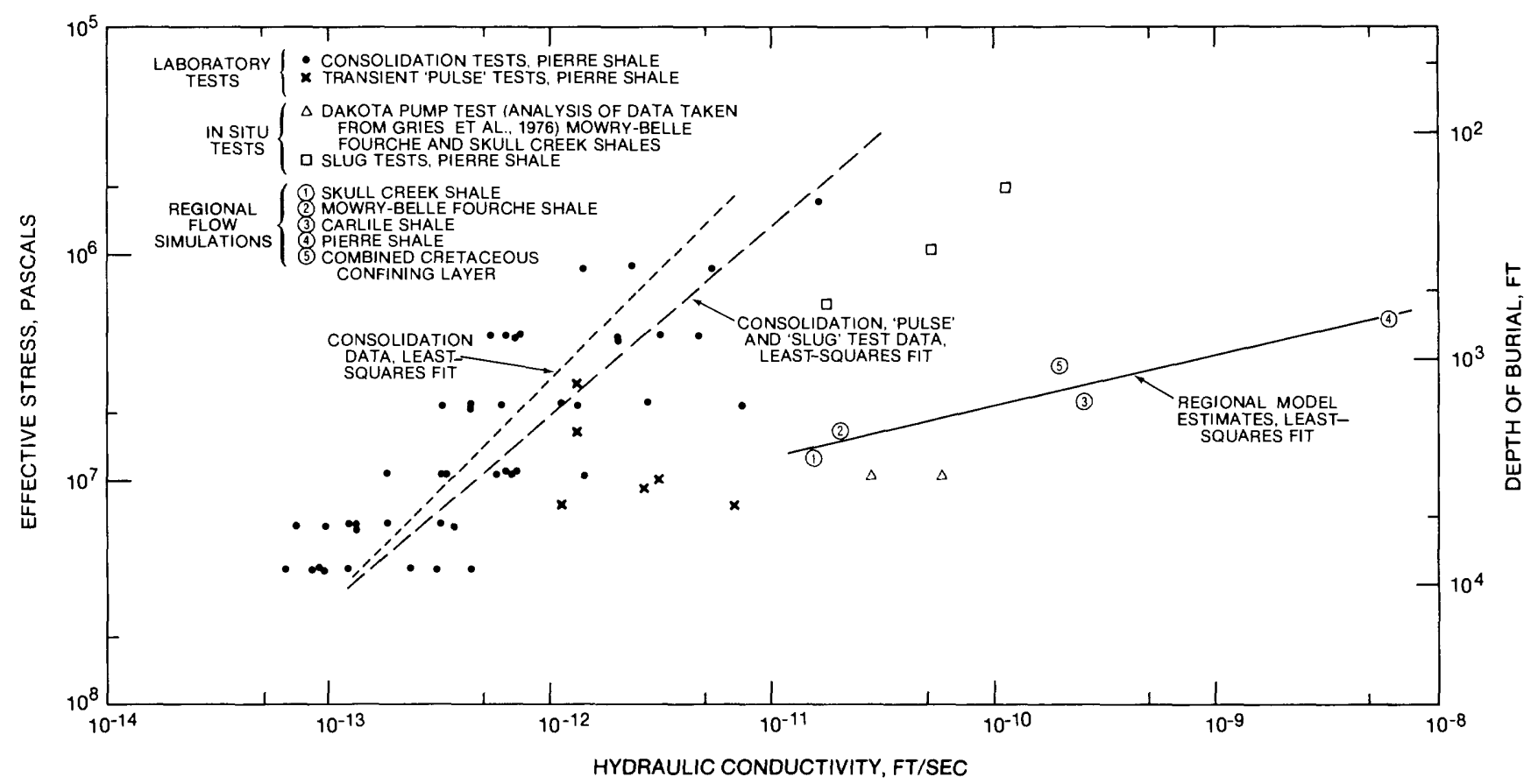

Figure 23. Summary of hydraulic conductivity data for the Cretaceous shale confining layer plotted as a function of depth of burial, or equivalent effective stress.

tive stress, or equivalent depth of burial. For the laboratory data, the vertical scale represents the effective stress during the test and generally not the depth at which the sample was obtained. For the in situ and regional values, the vertical scale represents the mean depth of the unit or test section.

Unlike the hydraulic conductivity, specific storage does not exhibit a tendency to change with depth. Nearly all the laboratory and in situ data fall in the range of $1 \times 10^{-6}$ to $2 \times 10^{-5} \mathrm{ft}^{-1}$.

The most consistent set of data comes from the consolidation results. These data group within one-half an order of magnitude at approximately $1 \times 10^{-5} \mathrm{ft}^{-1}$. The consolidation results are most consistent with those yielded by the regional flow simulations.

The flow simulations yielded somewhat larger values of specific storage than the other data. Several decades of aquifer development were simulated, and the specific storage determined is for the entire period. The laboratory and in situ tests, which are much shorter in duration, yielded smaller values for specific storage. These results are not surprising, considering the viscoelasticity of the Cretaceous shales. Part of the response of the shale structure to changes in effective stress (as a result of changes in potentiometric head) is time dependent. Compression of the shale and release of water accompanying a head decrease will be greater over longer periods of time.

\section{TRANSPORT OF SULFATE IN THE GROUND WATER}

We have presented numerical flow simulations which reproduce the regional potentiometric head distribution in the aquifers reasonably well. The fact that one can reproduce the observed hydraulic data using a conceptual model of the ground-water flow system does not prove that the model is correct; it merely shows that it is consistent with the data. In many, if not most, groundwater systems, sufficient degrees of freedom exist so that a unique solution cannot be determined. A potential means of eliminating one or more of the feasible models is to impose more constraints; that is, one must make use of additional information in testing for feasibility. Depending upon the extent to which a model is consistent with the new observed data, it may be retained, modified, or discarded.

In this analysis, we have utilized observed concentrations of sulfate in the ground water as an additional constraint on the model and have simulated the sulfate concentrations in an attempt to further our understanding of the ground-water system. The convective-dispersive solute-transport equation for sulfate was solved for the Inyan Kara aquifer and the Dakota-Newcastle aquifer separately, and the solutions were compared to the known concentration distributions. The Madison 
aquifer, which is believed to contain significant distributed sulfate sources in the form of anhydrite beds, was not modeled because of the added complexity of simulating the anhydrite dissolution process and the lack of knowledge of the distribution of these sources.

Our approach was to treat the sulfate as conservative within both the Inyan Kara and the Dakota-Newcastle sandstones. Obviously, this is a simplifying assumption; the geochemistry of the system is much more complex. However, if this simplified approach could produce sulfate distributions which resemble, in some sense, the observed distributions, it would lend support to our conception of the flow system.

\section{Distribution of Sulfate}

Tullis and others (1954) compiled all of the available published and unpublished water analyses for the State of South Dakota. There is no question that distinct patterns in the distribution of dissolved constituents exist in the Dakota water as Russell (1928), Swenson (1968), and others have indicated. The sulfate concentrations in the Dakota-Newcastle Sandstone are mapped in figure 25 .

The pattern can be interpreted as due, in part, to the stratigraphy of the aquifer. West of the pinchout of the Skull Creek Shale, data used for this map comes from the Newcastle, or upper Dakota aquifer sandstone. The sulfate concentrations in the Inyan Kara Group sandstones are mapped in figure 26 and show a different areal distribution than those in the DakotaNewcastle. The concentration of sulfate in the Inyan Kara aquifer increases to a maximum of $3,000 \mathrm{mg} / \mathrm{L}$ just west of the Skull Creek Shale pinchout. The area of maximum sulfate concentration in the Dakota-Newcastle is much farther east, in the vicinity of the James River Lowland.

\section{Simulation of Sulfate Transport}

The partial differential equation which describes solute transport is the advective-dispersive equation. For simplicity, we solved it for a two-dimensional areal region representing one aquifer; water in the aquifer was assumed to be well mixed vertically, and leakage through confining layers was treated as a source or sink.

If the solute concentrations are not excessively large $(<10,000 \mathrm{mg} / \mathrm{L})$, the velocity distribution in the aquifer is not significantly affected by density effects and is fully determined by the flow model. The results of simulations using the three-aquifer model were used to determine flow velocities within the aquifer and the rates of leakage leaving or entering the aquifer.
Following Bredehoeft and Pinder (1973, p. 202), we can write a two-dimensional equation for the change in concentration of a particular ion, in this case sulfate;

$$
\begin{aligned}
& -\left(\bar{q}_{x}^{*} \frac{\partial C_{s}}{\partial x}+\bar{q}_{y}^{*} \frac{\partial C_{s}}{\partial y}\right)+\frac{\partial}{\partial x}\left(D_{x x}^{*} \frac{\partial C_{s}}{\partial x}+D_{x y}^{*} \frac{\partial C_{s}}{\partial y}\right) \\
& +\frac{\partial}{\partial y}\left(D_{y y}^{*} \frac{\partial C_{s}}{\partial y}+D_{y x}^{*} \frac{\partial C_{s}}{\partial x}\right) \\
& =b \frac{\partial C_{s}}{\partial t}+Q^{*}\left(C_{s}^{\prime}-C_{s}\right)
\end{aligned}
$$

where $\bar{q}^{*}=b \bar{q} / \epsilon\left(L^{2} / T\right) ; \bar{q}$ is the specific discharge of Darcy's Law defined by $\bar{q}=-K \nabla h, K$ is aquifer hydraulic conductivity $(\mathrm{L} / \mathrm{T}), \epsilon$ is the effective porosity of the medium $\left(\mathrm{L}^{3} / \mathrm{L}^{3}\right)$, $\mathrm{b}$ is the thickness of the aquifer $(\mathrm{L})$,

$\mathrm{C}_{\mathrm{s}}$ is the concentration of dissolved sulfate, or mass of sulfate per volume of solution $\left(\mathrm{M} / \mathrm{L}^{3}\right)$,

$\mathrm{C}_{\mathrm{s}}^{\prime} \quad$ is the concentration of dissolved sulfate at a source or $\operatorname{sink}\left(\mathrm{M} / \mathrm{L}^{3}\right)$,

$\mathrm{Q}^{*}$ is defined by $\mathrm{Q}^{*}=\mathrm{Qb} / \epsilon(\mathrm{L} / \mathrm{T}), \mathrm{Q}$ is the rate of production of the source or sink as a volume rate per unit volume $\left(\mathrm{T}^{-1}\right)$,

$D^{*}=\mathrm{Db} / \epsilon$ is an effective dispersion coefficient for the entire thickness of aquifer $\left(\mathrm{L}^{3} / \mathrm{T}\right)$, $\mathrm{D}=\alpha \overline{\mathrm{v}}$ is the aquifer dispersion coefficient

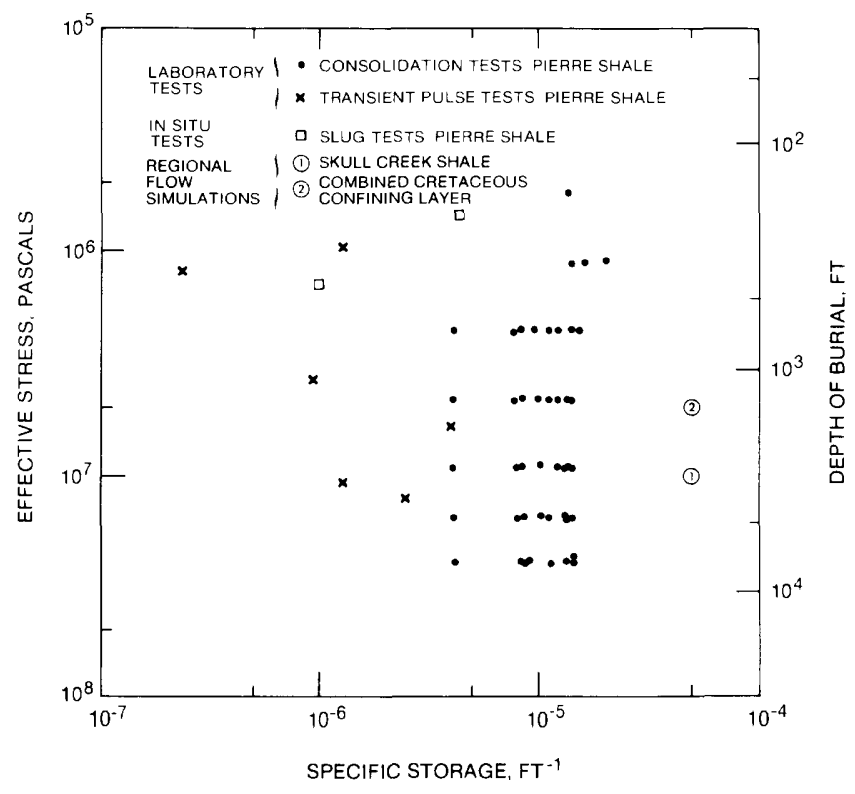

Figure 24. Summary of specific storage data for the Cretaceous shale confining layer plotted as a function of depth of burial, or equivalent effective stress. 


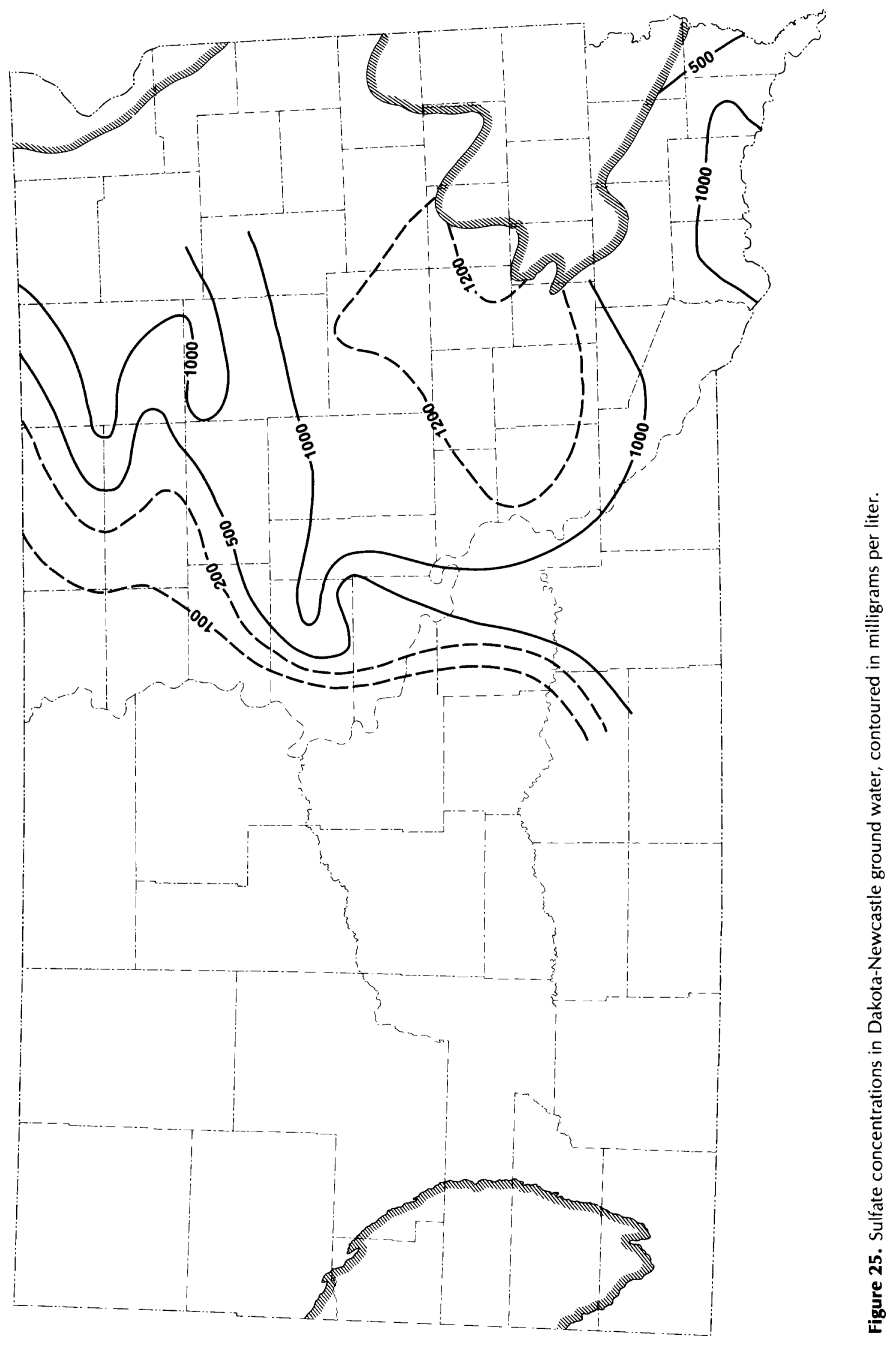




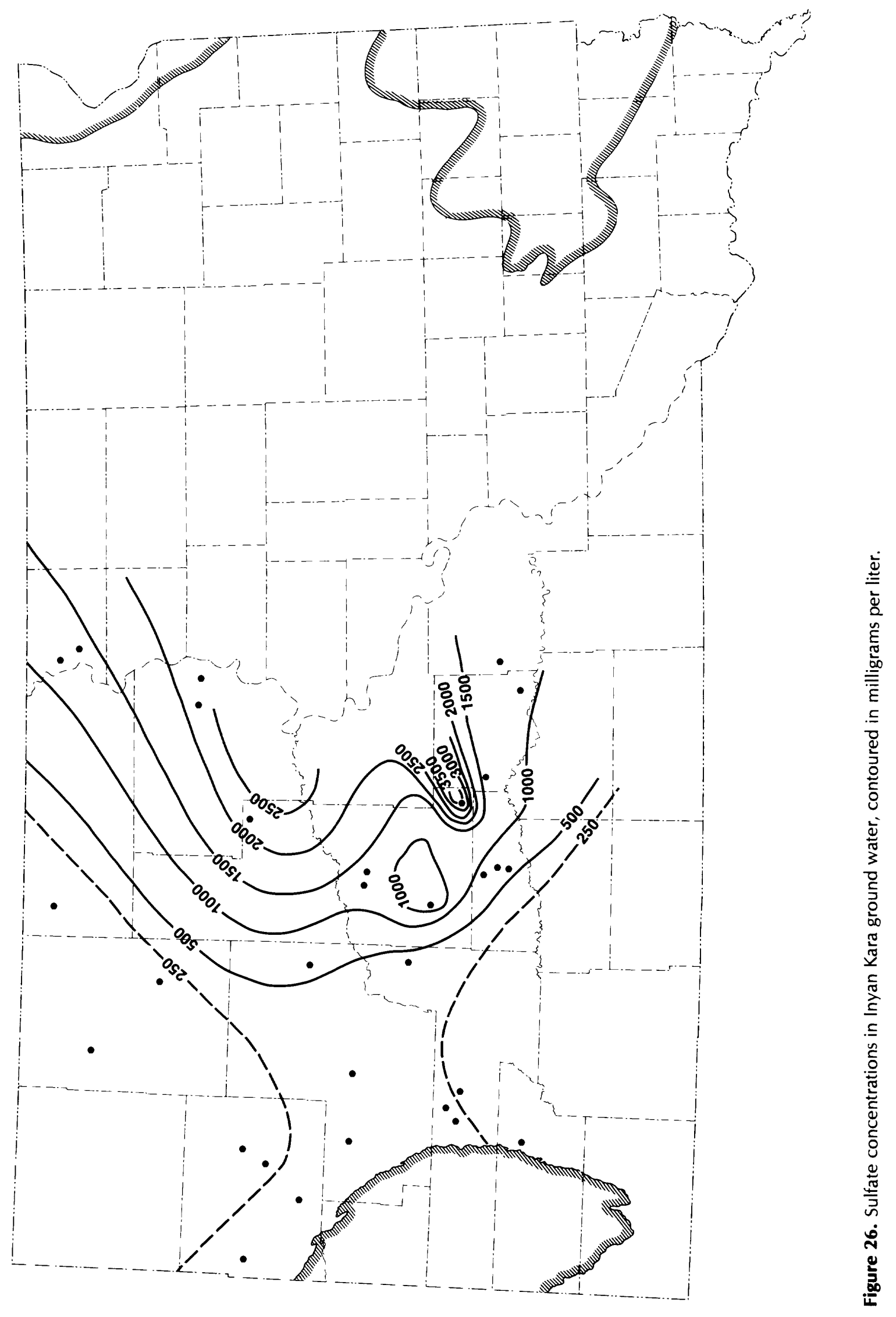


$\left(\mathrm{L}^{2} / \mathrm{T}\right), \alpha$ is the dispersivity $(\mathrm{L}), \overline{\mathrm{v}}=\overline{\mathrm{q}} / \epsilon$ is the average ground-water velocity $(\mathrm{L} / \mathrm{T})$.

Equation 11 was solved by using the finite-element computer program ISOQUAD (Pinder, 1974) using square linear elements. The nodal spacing (approximately $16.6 \mathrm{mi}$ ) was exactly double that used in flow models one, two and three and identical with that in flow model four. As noted above, the sulfate transport was simulated separately in the Dakota and Inyan Kara aquifers; the Dakota model consisted of 320 nodes and 275 elements, while the Inyan Kara model had 286 nodes and 245 elements.

Additional boundary conditions are required to solve the transport equation. At the outcrops in the Black Hills areas of recharge, the concentration was fixed at the value observed in the aquifer in the vicinity of the outcrop. A second type of boundary condition, zero-concentration gradient, was imposed at the zone of discharge from the Dakota outcrops in the east; this allowed the sulfate to leave the aquifer only through advection. The concentration of incoming leakage was assumed to be known and that of outgoing leakage was assumed to be equal to the aquifer fluid concentration at the point where leakage occurs. The sandstones themselves were assumed to be free of sulfate sources or sinks. This means that there was neither solution nor precipitation of the sulfate; mass transfer between the liquid and solid phases was assumed to be negligible.

\section{Sulfate Transport in the Inyan Kara Group Sandstones}

The steady-state concentrations of sulfate in the Inyan Kara were computed using the mass transport numerical simulations in conjunction with the results of the flow simulations. Hydraulic conductivity and thickness of the aquifer were as defined for the three-aquifer flow model. The porosity was assigned a value of 0.20 . The transverse and longitudinal dispersivities of the medium were arbitrarily set equal to $75 \mathrm{ft}$; later simulations demonstrated that, at this scale, the calculated concentrations are extremely insensitive to the dispersivity values. The sulfate concentration in leakage from below the aquifer was taken to be $1,500 \mathrm{mg} / \mathrm{L}$. This high value is consistent with the water chemistry of the Madison and, more importantly, with the presence of anhydrite in the intervening confining layer. Both the Spearfish and the Minnelusa Formations, which are part of the confining layer overlying the Madison aquifer, have bedded anhydrite in western South Dakota (fig. 27). It is expected that the geochemistry of the confining layer will be reflected in the leakage to the Inyan Kara from below to a greater extent than will the water chemistry of the Madison; for this reason, a uniform concentration was assigned to the leakage.

The computed Inyan Kara sulfate concentrations are shown in figure 28. Considering the simplicity of the assumptions concerning the source of the sulfate, the results appear to us to be satisfactory. How good the fit is between observed (fig. 26) and calculated (fig. 28) concentrations is a matter of judgement. A number of other conceptual sources for the sulfate were tried. Only the system in which the source of the sulfate was leakage from below gave results even approaching the observed distribution. The chief discrepancies of the computed concentrations are a lower east-west concentration gradient and an absence of the regional high in the westcentral area. If the basic conceptual model of the system is correct, these differences could easily be accounted for by areal variations in the chemical composition of the leakage from the Madison confining layer. This result only indicates that the source of the sulfate in the Inyan Kara is not inconsistent with our concept of the flow system.

\section{Sulfate Transport in the Dakota-Newcastle Sandstone}

Again using the results of the flow simulations to determine the velocity and leakage distributions, the steady-state sulfate concentrations in the Dakota-Newcastle were calculated. The transverse and longitudinal dispersivities were initially given the value of $75 \mathrm{ft}$, and the porosity was assumed to be 0.20 . Leakage from below the Dakota was assumed to have a concentration equal to the observed value in the Inyan Kara at the point of upward leakage (see fig. 26). Leakage from the shales overlying the Dakota was assumed to have a sulfate concentration of $100 \mathrm{mg} / \mathrm{L}$.

The dominance of advective over dispersive transport was demonstrated when different dispersivity values were tried in the simulations. Even when the dispersivity was made as large as $2 \times 10^{4} \mathrm{ft}$, computed concentrations did not change substantially. The large dispersivities had the advantage of damping "overshoot" and "undershoot" errors (Pinder and Gray, 1977) which occur where concentration gradients change rapidly. Thus, we present the concentrations in the Dakota-Newcastle computed with a very large $\left(2 \times 10^{4} \mathrm{ft}\right)$ dispersivity (fig. 29).

The computed concentrations correctly reproduce the general east-west gradient. In addition, the regional high in the computed values is located just northwest of the Sioux Ridge, a result which is in general agreement with the field data (fig. 25). South of the Sioux Ridge, in the southeast corner of the model area, concentrations decrease due to dilution by recharge from the surface. 


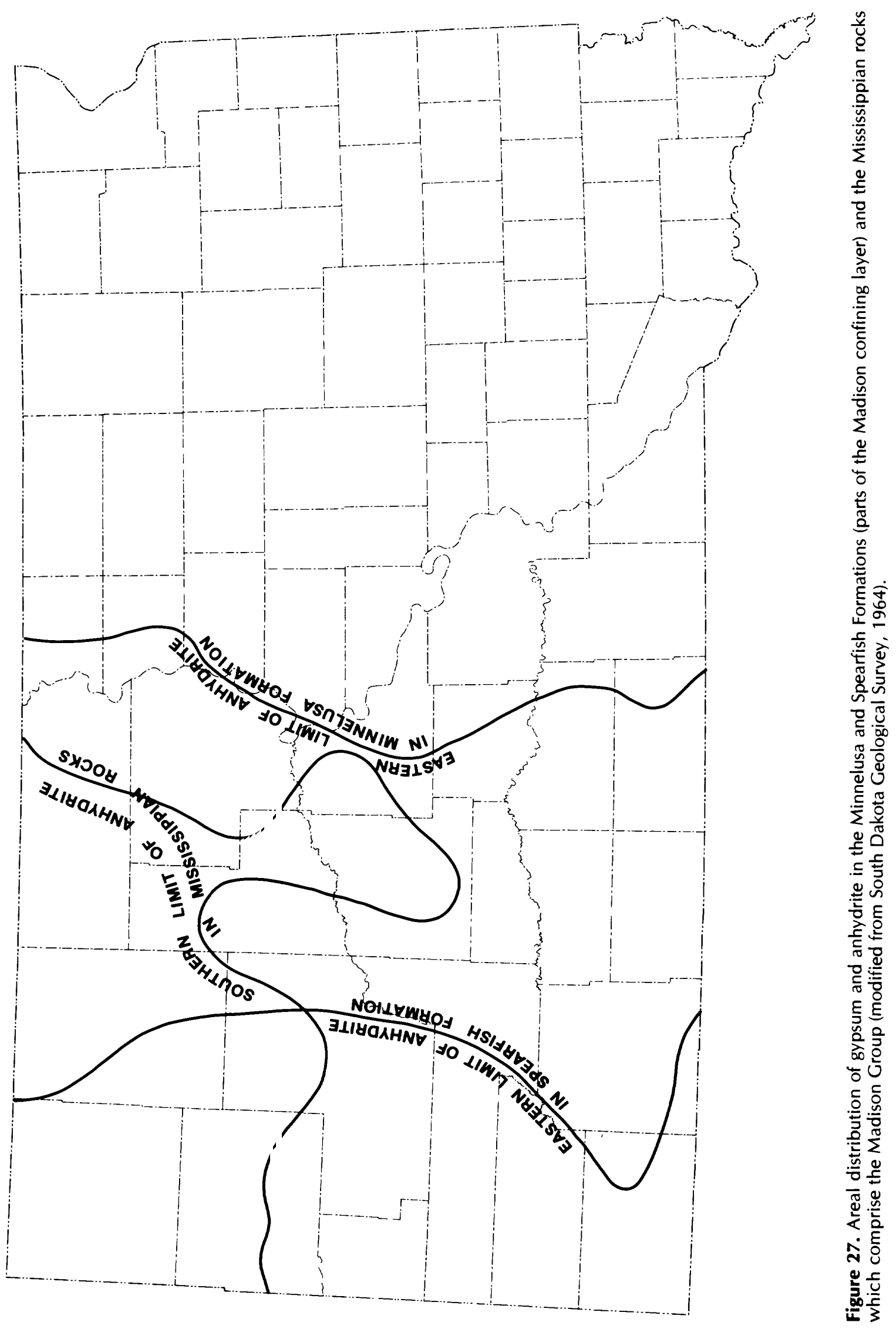

35 


$$
\frac{x_{n} z_{3}}{a_{3}}
$$




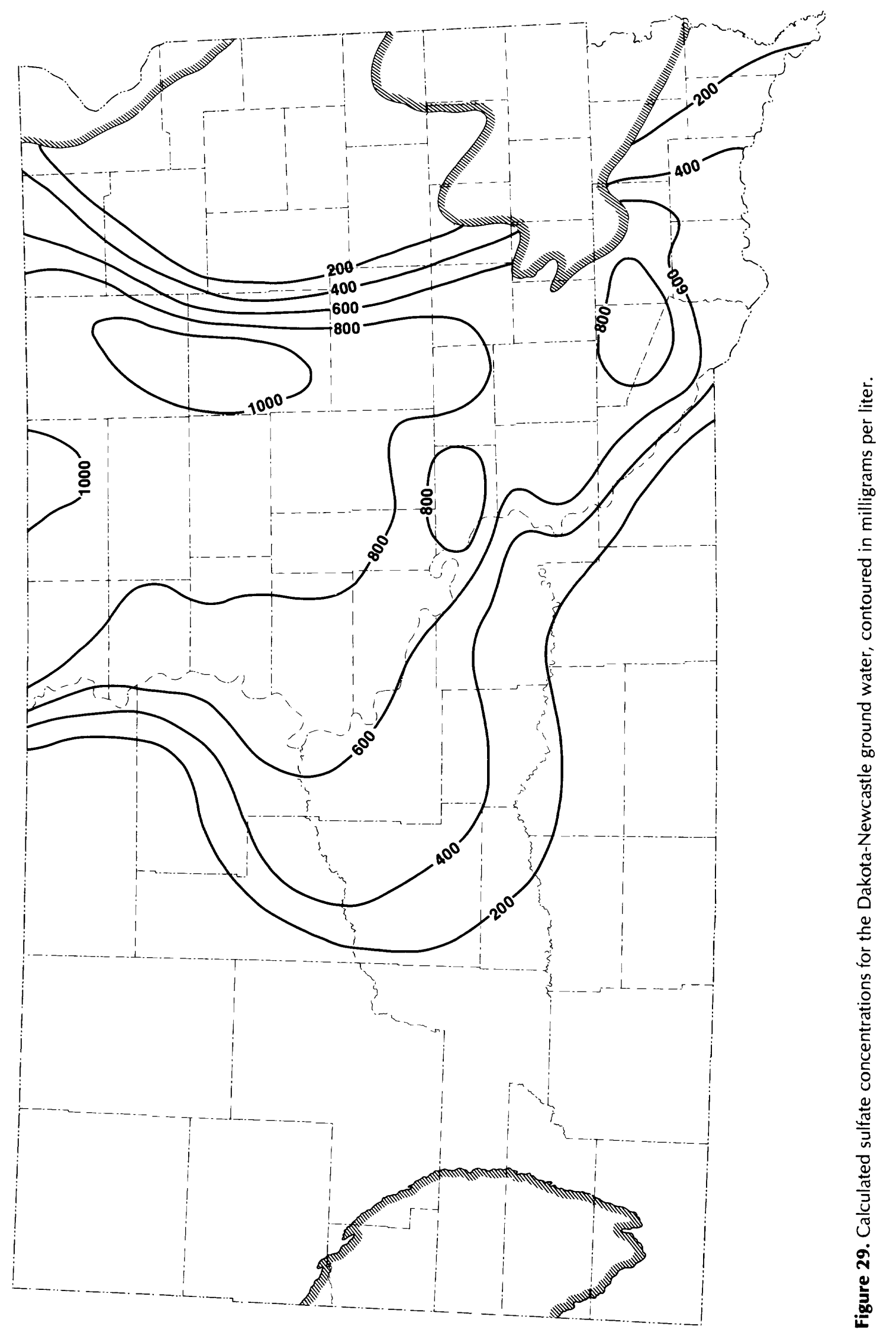


This is also expected from the observed data. The same phenomenon appears to occur north of the Sioux Ridge, although there are no observations either to confirm or to refute this possibility.

Two deficiencies of the computed values are obvious. A region of concentrations as high as 600 to 800 $\mathrm{mg} / \mathrm{L}$ appears west of the Missouri River; in this area, the observed concentrations are less than $100 \mathrm{mg} / \mathrm{L}$. In the eastern part of the State, north of the Sioux Ridge, dilution of the Dakota water occurs farther west than the field data indicate.

The most serious error in the computed values is the area of fairly high concentrations west of the Missouri River. In this regard, it is important to review the assumptions associated with our simulations. The source of this excess sulfate is the steady-state upward leakage through the Skull Creek Shale; this leakage is assumed to have a sulfate concentration equal to that of water in the underlying Inyan Kara Group (fig. 26). Furthermore, it is assumed that the leakage rates are determined by the equation of flow, independent of the distribution of sulfate in the ground-water system.

It is pertinent to question whether the system has reached steady state with respect to concentration (we define steady state as $\partial \mathrm{C}_{\mathrm{s}} / \partial \mathrm{t}=0$ ), or whether it could still be in a transient state with respect to concentration of dissolved species $\left(\partial \mathrm{C}_{\mathrm{s}} / \partial \mathrm{t} \neq 0\right)$.

If a transient state exists, a sulfate front might be advancing upward through the Skull Creek Shale. In the east, where the shale is either thin or absent, the sulfate would have broken through into the Dakota. Farther west, where the Skull Creek Shale thickens and leakage rates are lower, the front would still be within the shale beds, having not yet reached the Dakota Sandstone. Because our simulations are for steady-state conditions, discrepancies between computed and observed concentrations might be partially due to the existence of a transient state in the ground-water system with respect to dissolved species.

We have made a simple calculation to examine the question of transient conditions with respect to concentration. The results of mercury injection tests suggest that the Cretaceous shale has an effective porosity which ranges from 0.04 to 0.10 . Leakage rates calculated using the flow model are on the order of $10^{-11}$ $\mathrm{ft} / \mathrm{sec}$ which corresponds to an average water velocity of $10^{-10} \mathrm{ft} / \mathrm{sec}$, assuming an effective porosity of 0.1 . The average traveltime for leakage from the Inyan Kara to the Dakota is then equal to the thickness of the shale divided by this velocity; for a 300 -ft thickness, the traveltime is estimated to be $3 \times 10^{12} \mathrm{sec}$, or approximately 100,000 years. Had we assumed an effective porosity of 0.01 , the estimated traveltime would be approximately 10,000 years. The present tectonic setting existed in Oligocene time, or approximately 25 million years ago (Eardley, 1962). This would suggest that the boundary conditions and, therefore, the flow system have existed in something like their present form for approximately 25 million years and that steady-state conditions with respect to concentration exist.

However, if flow through the confining layers is dominantly in fractures, the traveltimes could be significantly more than the calculation above indicates. Grisak and Pickens (1980) and Neretnieks (1980) have shown that the transport of dissolved species through fractures can be significantly retarded by diffusion into the intergranular pores along the fracture walls. In effect, the dissolved constituent is stored in the rock matrix near the fracture walls. Under these circumstances the solute may not yet have "broken through," even though flow through the fractures has been occurring for a long period of time. In addition, short-duration changes in the boundary conditions may have occurred during Pleistocene glaciation; dissolved species concentrations could still be adjusting to these relatively recent changes.

\section{The Role of Geological Membranes in the Transport of Sulfate}

A potential weakness of the mass transport models suggested so far is their failure to consider all of the physical and chemical phenomena which govern transport. The electrical properties of clay minerals make it possible for clay and shale layers to behave as semipermeable membranes (Hanshaw and Hill, 1969; Kharaka and Berry, 1973). The effect influences both fluid flow and mass transport. A difference in concentration across the membrane results in an osmotic pressure difference which will affect the fluid flow. The membrane will tend to build and maintain concentration differences as a result of solute filtering. An experimental investigation of this filtering by Kharaka and Berry (1973) yielded influent-effluent sulfate concentration ratios of about 2.0 for a thin bentonite filter at $8,000 \mathrm{lb} / \mathrm{in}^{2}$ compaction pressure.

Bredehoeft and others (1963) developed an analytical model to simulate mass transport in a system containing a geological membrane and used the model to show that the membrane effect might be responsible for the concentration of brines in the Illinois basin. It is possible that the Cretaceous shales in this study behave as semipermeable membranes, or as a series of membranes, and, as such, affect significantly the distribution of sulfate in the system.

To test the effect of the filtration phenomenon on sulfate transport in the system, several simplifying assumptions were made. No rigorous justifications for these assumptions are offered. It is expected, however, 
that the results should at least qualitatively reflect the influences of the membrane effect. The assumptions are as follows:

1. The osmotic pressure effect of concentration differences across a membrane is negligible. The effect of the filter on the flow system was ignored, although the effect on mass transport was considered. The flow equation thus remained independent of concentration; the flow simulations, as developed above, were assumed to apply.

2. A shale layer such as the Skull Creek Shale consists of several "filtration cells." The characteristic thickness, $b^{*}$, of the filtration cell is a function of the pattern of sedimentary layering and the distribution of clay minerals in the shale. This assumption offers a practical means of applying the concept of an ideal filter to real geologic environments.

3. The effect of a filtration cell can be characterized by a single parameter, $\mathrm{f}$, the filtration ratio, as defined by Kharaka and Berry (1973):

$$
\mathrm{f}=\mathrm{m}_{\mathrm{i}} / \mathrm{m}_{\mathrm{i}}^{*} \text {, }
$$

where $m_{i}$ is the concentration of the species in the influent solution and

$\mathrm{m}_{\mathrm{i}}^{*}$ is its concentration in the effluent solution.

4. The value of $f$ is independent of fluid flow rate through the cell. Although it is known that a relationship does exist, the dependency is only poorly understood. Because the computed leakage rates through the Skull Creek Shale are mostly within one order of magnitude, this assumption is probably acceptable for the purposes of analysis.

5. The value of $f$ is a constant property of the shale, although it is known to vary with the exchange capacity of the medium. This assumption is an extension of the assumption of homogeneity with respect to hydraulic conductivity. Because areal variations of exchange capacity are not known, we assumed a constant filtration ratio.

On the basis of these assumptions, the net filtration ratio of an entire shale layer, F, was computed as the product of the filtration ratios of each of its constituent filtration cells:

$$
F=\prod_{i=1}^{n} f_{i}
$$

where the integer $\mathrm{n}$ is approximately equal to the shale thickness, $b$, divided by the characteristic thickness, $b^{*}$, of a filtration cell,

$$
\mathrm{n}=\mathrm{b} / \mathrm{b}^{*} \text {. }
$$

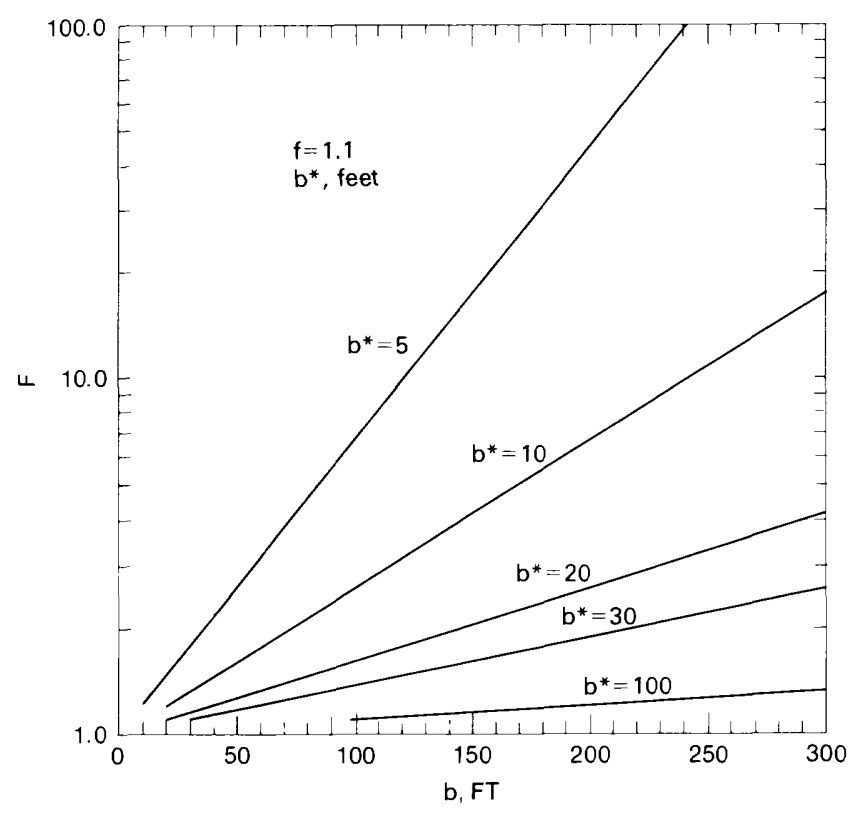

Figure 30. Net filtration ratio, $F$, as a function of shale thickness, $b$, for various values of filtration cell characteristic thickness, $b^{*}$.

From our assumptions, $f$ is assumed constant within the shale, so

$$
\mathrm{F}=\mathrm{f}^{\mathrm{n}}
$$

With the filtration model described above, the problem of sulfate transport in the system can be restated. The only changes to the transport simulation are in the form of changed concentrations for the leakage. The concentration of leakage entering the Dakota-Newcastle Sandstone through the Skull Creek Shale from the Inyan Kara Group is given by $c_{i} / F$, where $c_{i}$ is the concentration in the Inyan Kara. The concentration of the leakage out of the Inyan Kara aquifer is given by $c_{i} / f$. The concentration of the leakage out of the DakotaNewcastle aquifer is given by $c_{d} / f$, where $c_{d}$ is the concentration in the Dakota-Newcastle. The concentration of the leakage into the Dakota-Newcastle aquifer from above is taken as constant at $100 \mathrm{mg} / \mathrm{L}$, the same concentration used in the simulations without membrane effects.

The value chosen for the filtration ratio, $\mathrm{f}$, is 1.1 , a number which is in accordance with the experimental results of Kharaka and Berry (1973). For simulating the Dakota-Newcastle, this value is used for both the underlying Skull Creek Shale and for the overlying shales. Values of $F$ as a function of $b$ and $b^{*}$, for $f=1.1$, are plotted in figure 30 .

This formulation envisions the shale as a number of individual membrane filters linked in series. It has the 


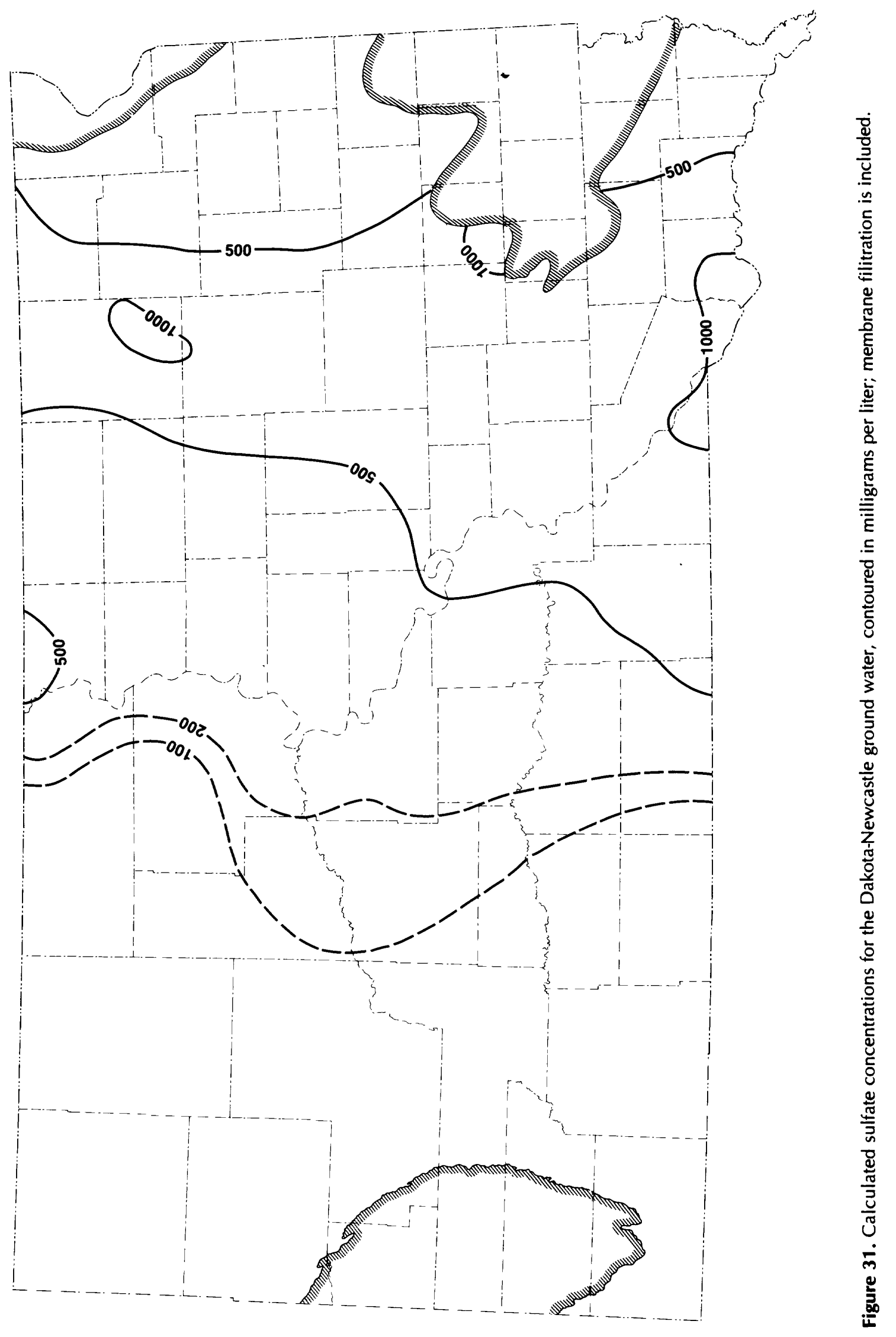




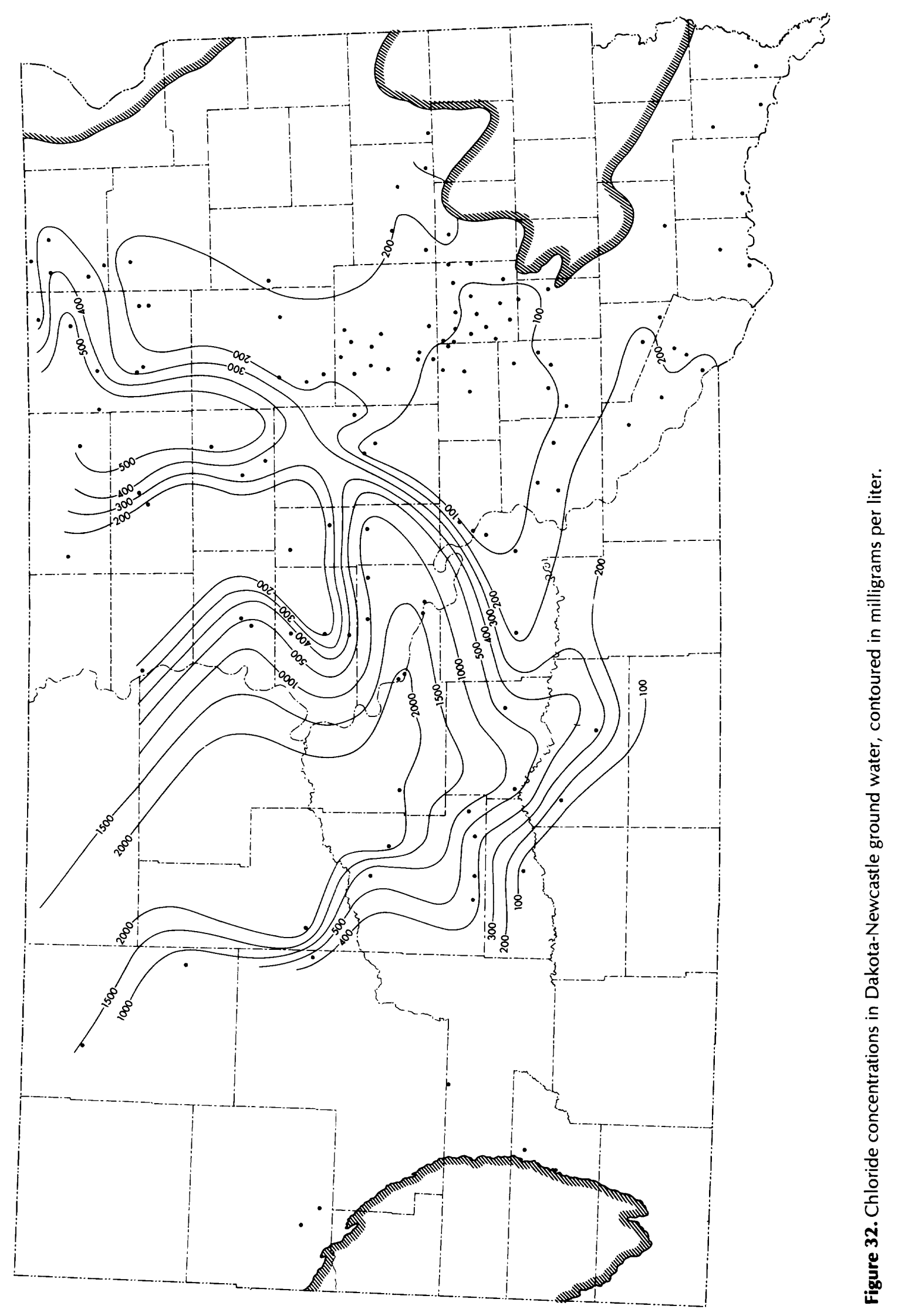


nice property that, as the shale thickens, the membrane improves in net efficiency. It has the disadvantage that the characteristic filtration cell thickness, $b^{*}$, is unknown and, in our case, must be determined by trial and error.

The transport of sulfate was computed for the Dakota-Newcastle aquifer with the membrane effects included, as discussed above; the results are shown in figure 31. Adding the effects of filtration lowers the calculated concentrations west of the Missouri River; in general, we believe it improved the solution.

The calculated solution is sensitive to the value of $b^{*}$. For large values of $b^{*}$, the shale is a rather inefficient filter. For small values of $b^{*}$, the shale is an effective filter even where it is very thin. The value which gave the best results is $b^{*}$ equal to approximately $20 \mathrm{ft}$.

\section{CHLORIDE IN THE GROUND WATER}

The chloride concentrations in the Dakota-Newcastle aquifer are mapped in figure 32. The distribution of chloride within the aquifer is puzzling. There is little doubt that flow occurs from west to east through the aquifer. With this flow system, it is difficult to understand the concentration of chlorides that remains near the center of the flow system. The higher chloride content appears to be related to the structural axis of the Williston Basin. Several efforts to simulate the chloride concentrations were unsuccessful.

\section{DISCUSSION}

We approached this study with the deductive hypothesis, or bias if you like, that leakage through the shale confining layers forms a significant, if not dominant, element of the Dakota flow system. This is not a new idea; as pointed out in the introduction, both Chamberlin (1885) and Darton (1909) expressed versions of this concept around the turn of the century. We have attempted to test the validity of this hypothesis using presently available quantitative techniques. In the process, we have estimated, within reasonable limits, numerical values for the parameters which describe the system. Indeed, the analysis has led to interesting ideas and speculations about shale confining layers.

Some data, most notably the chloride distribution in the Dakota-Newcastle aquifer, remain to be explained. However, this appears to reflect our poor understanding of certain details of the aquifer system and the geochemistry. We believe that, with this exception noted, the flow system we have hypothesized is consistent with the data as we have interpreted them.
We have not validated the hypothesis, we have simply not invalidated it-an important philosophical distinction. The scientific philosopher K. R. Popper, in 1959 argued in his book, The Logic of Scientific Discovery, that scientific laws, theories, and hypotheses cannot be validated, they can only be "falsified" or invalidated. We concur with Popper's view of science on this point. Accepting this viewpoint leads to the outlook that one cannot validate a particular model; one can only answer the question, is the model consistent with the data? Indeed, there may be other models which are also consistent with the data. How one views the data depends upon his model, or hypothesis, of how the system operates.

The pumping test at Wall, South Dakota, illustrates our point. An analysis of the Wall results using the Theis assumptions-no flow through the confining layers-indicates that the data are consistent with this hypothesis, within experimental error, for the period of time the test was conducted; that is, $44 \mathrm{hr}$ (Gries and others, 1976). The same data are also consistent with an analysis based upon the modified leaky aquifer theory of Hantush (1960) which includes both flow and storage in the confining layers, as was pointed out above. The duration of the Wall pumping test was not sufficient to invalidate the hypothesis of leakage at the rates which the numerical simulations indicate; in that context, the experiment was not definitive. The pertinent point is that neither analysis is wrong; they simply depend upon the deductive hypothesis one believes is more appropriate.

It would be foolish on our part to believe that we have written the last word concerning the Dakota aquifer system. As N. Wood Bass, a distinguished geologist with the U.S. Geological Survey, stated, "any geological report is simply a progress report." Popper (1959) also states the same conclusion:

"The game of science is, in principle, without end. He who decides one day that scientific statements do not call for any further test, and that they can be regarded as finally verified, retires from the game."

\section{Simplifying Assumptions}

In making our analyses we have made quite a number of important simplifying assumptions. We have assumed:

1. The aquifers which control the flow are the Dakota, which we subdivided in the western part of the study area into the Inyan Kara Group sandstones and overlying Dakota-Newcastle Sandstone, and the underlying Madison Group limestones.

2. The confining layers can be idealized into those which separate the principal aquifers. This is certainly a major simplification; the confining layers, 
as defined by us, contain a number diverse lithologic units. This is particularly true for the confining layer that separates the Dakota from the Madison. Our analysis of the confining layer which overlies the Dakota indicated that this unit is more complex hydrologically than our earlier models allowed.

3. Single values of the hydraulic parameters characterize the various units of the system: hydraulic conductivity, specific storage, porosity, filtration ratio, and characteristic filtration cell dimension. For the numerical simulations, the geometry of the geologic setting and the thickness of confining layers and aquifers were included in our analyses.

4. The flow and solute transport were in steady state prior to development.

5. No sulfate sources or sinks are present in the Inyan Kara Group, the Skull Creek Shale, or the DakotaNewcastle Sandstone.

6. Membrane phenomena may affect solute transport but do not affect the ground-water flow.

Even with these rather restrictive simplifying assumptions the results are surprisingly consistent with the observations. The fact that we can make these simplifying assumptions and still get reasonable results is encouraging.

\section{CONCLUSIONS}

There are a number of interesting conclusions which stem from the investigation:

1. Our analysis indicates that under steady-state conditions leakage through the shale confining layers was the most important component of the flow system (see fig. 16).

2. To account for the rather small drawdown which has accompanied development of the Dakota, our analysis indicates that most of the water released from storage must have been derived from the confining layers.

3. Comparison of the hydraulic conductivity values derived from regional model analyses with the in situ and laboratory determinations suggests that much of the flow through the Cretaceous shale confining layers probably occurs as flow through fractures.

4. Upward leakage from lower units is the predominant source of sulfate in the Inyan Kara and Dakota aquifers. The calculated sulfate concentration distributions are consistent with those observed. These results art consistent with Swenson's (1968) concept of flow in the system. Our analysis further suggests that, of the approximately $80 \mathrm{ft}^{3} / \mathrm{sec}$ which was discharged from the Dakota system under virgin conditions, about 25 percent came from the Madison aquifer (see fig. 16).

\section{ACKNOWLEDGMENTS}

This investigation has had a long and checkered history. The principal investigator joined the U.S. Geological Survey in 1962 to work with Robert R. Bennett on a study of the hydrodynamics of the Tensleep Sandstone in the Big Horn Basin of Wyoming. It was from that investigation that many of the ideas concerning regional flow systems, especially the role of thick shale confining layers, were formulated. An analysis of the Tensleep flow system was attempted using an electric analog model; unfortunately, the results of that analysis were not published.

Swenson's (1968) paper stimulated more thinking about regional flow, this time in the Dakota aquifer. Flow in the Dakota became the subject of a graduate seminar in ground-water hydrology which the principal investigator taught as a visiting professor at the University of Illinois in 1968. As part of that seminar, the class visited South Dakota where we met Martin Sather, a driller in Presho, South Dakota. Mr. Sather generously allowed us to examine the records of the Norbeck and Hollis Drilling Company, records which provided invaluable information concerning the hydraulic conductivity of the Dakota aquifer.

The seminar at the University of Illinois resulted in the early simplified model of the system, a model which included only the Dakota aquifer. A manuscript, in which the seminar members-R. T. Getzen, M. R. McComas, R. Piskin, P. C. Rao, C. A. Rodriques, and C. H. Simonds-participated, described the early model analysis; this manuscript was distributed widely for review. Among the reviewers were S. W. Lohman and F. A. Swenson. The reviews pointed out weaknesses in the early analysis. Among the weaknesses were that the analysis did not include the Madison aquifer and that it hypothesized an explanation for the sulfate in the Dakota which could not be supported when one examined that data more carefully.

Further, more detailed analysis required more sophisticated multiaquifer digital models than were available in 1968. For that reason, and the press of other work, the study languished.

Carolyn Showers, an undergraduate at Princeton University, developed a multiaquifer flow model of the system which included the Madison aquifer, while working at the U.S. Geological Survey during summer 1976. Christopher Milly, also an undergraduate at Princeton, built on Carolyn's model and added trans- 
port while working at the Survey during the following summer. Chris used the analysis of the Dakota aquifer, in particular the analysis of sulfate distribution, for his undergraduate thesis at Princeton.

During 1978, we drilled a series of test holes in South Dakota to better define the nature of the confining layer. Christopher Neuzil joined the staff of the project in 1978 and participated in the field and laboratory experiments. Chris used an analysis of toxic waste disposal in the Cretaceous shale for the subject of his Ph.D. dissertation in geology at Johns Hopkins University, a dissertation he completed in 1980.

All of these individuals, including the reviewers of our early manuscript, have contributed substantially to the ideas in this report.

Test drilling, core sampling, and hydraulic testing of the Pierre Shale is tricky business. We are indebted to our colleagues Roger Wolff, Robert Pemberton, Stavros Papadopulos, and Horace Sutcliffe, Jr., for their assistance in the test drilling. Much of the real credit goes to our driller, Bob Pemberton; it was his patience and ingenuity which made the coring and testing possible.

Numerous individuals in South Dakota provided valuable assistance during our field investigation. Without their help and cooperation, our job would have been much more difficult.

Finally, our colleagues who took the time to review the present paper deserve our thanks. We particularly wish to thank Charles Appel, Gordon Bennett, Leonard Konikow, and Mary Anderson for their helpful comments.

\section{REFERENCES}

Barkley, R. C., 1953, Artesian conditions in the area surrounding the Sioux Quartzite ridge: South Dakota Geological Survey Report of Investigations, no. 72, $68 \mathrm{p}$.

Bredehoeft, J. D., Blyth, C. R., White, W. A., and Maxey, G. B., 1963, Possible mechanism for concentration of brines in subsurface formations: American Association of Petroleum Geologists Bulletin, v. 47, no. 2, p. 257-269.

Bredehoeft, J. D., and Papadopulos, S. S., 1980, A method for determining the hydraulic properties of tight formations: Water Resources Research, v. 16, no. 1, p. 233-238.

Bredehoeft, J. D., and Pinder, G. F., 1970, Digital analysis of areal flow in multiaquifer groundwater systems: A quasi three-dimensional model: Water Resources Research, $v$. 6 , no. 3 , p. 883-888.

1973, Mass transport in flowing groundwater: Water Resources Research, v. 9, no. 1, p. 194-210.

Casagrande, Arthur, 1960, Karl Terzaghi, his life and achievements, in Bjerrum, Laurits, Casagrande, Arthur, Peck, R. B., and Skempton, A. W., eds., From Theory to Practice in Soil Mechanics, New York, John Wiley, p. 3-21.
Chamberlin, T. C., 1885, The requisite and qualifying conditions of artesian wells: U.S. Geological Survey Annual Report, no. 5, p. 125-173.

Darton, N. H., 1896, Preliminary report on artesian waters of a portion of the Dakotas: U.S. Geological Survey Annual Report, no. 17 , pt. 2, p. 609-691.

1901 , Geology and water resources of the southern half of the black Hills and adjoining regions in South Dakota and Wyoming: U.S. Geological Survey Annual Report, no. 21, pt. 4, p. 489-599.

1909, Geology and underground waters of South Dakota: U.S. Geological Survey Water-Supply Paper 227, $156 \mathrm{p}$.

Davis, R. W., Dyer, C. F., and Powell, J. E., 1961, Progress report on wells penetrating artesian aquifers in South Dakota: U.S. Geological Survey Water-Supply Paper $1534,100 \mathrm{p}$.

Dyer, C. F., and Goehring, A. J., 1965, Artesian-water supply of the Dakota formation, southeastern South Dakota: U.S. Geological Survey Open-File Report 65-51, 49 p.

Eardley, A. J., 1962, Structural geology of North America: New York, Harper and Row, 743 p.

Erickson, H. D., 1954, Artesian conditions in east-central South Dakota: South Dakota Geological Survey Report of Investigations, no. 74, $116 \mathrm{p}$.

1955, Artesian conditions in northeastern South Dakota: South Dakota Geological Survey Report of Investigations, no. $77,39 \mathrm{p}$.

Gill, J. R., and Cobban, W. A., 1965, Stratigraphy of the Pierre Shale, Valley City and Pembina Mountain Area, North Dakota: U.S. Geological Survey Professional Paper 392-A, 20 p.

1966, The Red Bird Section of the Upper Cretaceous Pierre Shale in Wyoming: U.S. Geological Survey Professional Paper 393-A, 73 p.

Gries, J. P., 1954, Cretaceous rocks of the Williston Basin: Bulletin of the American Association of Petroleum Geologists, v. 38 , no. 4, p. 443-453.

1958, The Dakota formation in central South Dakota: Proceedings of the South Dakota Academy of Science, $v$. 37, p. 161-168.

Gries, J. P., Rahn, P. H., and Baker, R. K., 1976, A pump test in the Dakota Sandstone at Wall, South Dakota: South Dakota Geological Survey Circular 43, 9 p.

Grisak, G. E., and Pickens, J. F., 1980, The effect of matrix diffusion, pt. 1 of Solute transport through fractured media: Water Resources Research, v. 16, no. 4, p. 719-730.

Hanshaw, B. B., and Hill, G. A., 1969, Geochemistry and hydrodynamics of the Paradox Basin region, Utah, Colorado, and New Mexico: Chemical Geology, v. 4, p. 263-294.

Hantush, M. S., 1960, Modification of the theory of leaky aquifers: Journal of Geophysical Research, v. 65, no. 11, p. 3713-3725.

Hsieh, P. A., Tracy, J. V., Neuzil, C. E., Bredehoeft, J. D., and Silliman, S. E., 1981, Theory, pt. 1 of A transient method for determining the hydraulic properties of "tight" rocks: International Journal of Rock Mechanics and Mining Sciences, v. 18, no. 3, p. 245-252. 
Jacob, C. E., and Lohman, S. W., 1952, Nonsteady flow to a well of constant drawdown in an extensive aquifer: Transactions of the American Geophysical Union, v. 33, p. 559-569.

Jorgenson, D. G., 1971, Geology and water resources of Bon Homme County: South Dakota Geological Survey Bulletin, no. 21 , pt. 1,48 p.

Kharaka, Y. K. and Berry, A. F., 1973, Experimental investigation, pt. 1 of Simultaneous flow of water and solutes through geological membranes: Geochimica et Cosmochimica Acta, v. 37, no. 12, p. 2577-2605.

Koch, N. C., 1970, Geology and water resources of Campbell County, South Dakota: South Dakota Geological Survey Bulletin, no. 20, pt. 2, 38 p.

Meinzer, O. E., 1928, Compressibility and elasticity of artesian aquifers: Economic Geology, v. 23, no. 3, p. 263-291.

Miller, R. H., and Rahn, P. H., 1974, Recharge to the Dakota sandstone from outcrops in the Black Hills, South Dakota: Bulletin of the Association of Engineering Geologists, v. 11 , no. 3, p. 221-334.

Neretnieks, Ivars, 1980, Diffusion in the rock matrix-An important factor in radionuclide retardation?: Journal of Geophysical Research, v. 85, no. B8, p. 4379-4397.

Neuzil, C. E., 1982, On conducting the modified "slug" test in tight formations: Water Resources Research, v. 18, no. 2, p. 439-441.

Neuzil, C. E., Cooley, Craig, Silliman, S. E., Bredehoeft, J. D., and Hsieh, P. A., 1981, Application, pt. 2 of A transient method for determining the hydraulic properties of "tight" rocks: International Journal of Rock Mechanics and Mining Sciences, v.' 18, no. 3, p. 253-258.

Niven, D. W., 1967, Determination of porosity and permeability of selected sandstone aquifers of South Dakota, M. S. Thesis, South Dakota School of Mines and Technology, Rapid City, South Dakota, 31 p.

Pinder, G. F., 1974, Galerkin-finite element model for aquifer simulation: Water Resources Program, Civil Engineering Department, Princeton University, Princeton, N.J.

Pinder, G. F., and Gray, W. G., 1977, Finite element simulation in surface and subsurface hydrology: New York, Academic Press, 295 p.

Piper, A. M., 1928, The origin of the artesian pressure: Economic Geology, v. 23, no. 6, p. 683-696.

Popper, Sir Karl, 1959, The logic of scientific discovery: New York, Harper and Row, $480 \mathrm{p}$.

Reeside, J. B., Jr., 1944, Maps showing thickness and general character of the Cretaceous deposits in the western interior of the United States: U.S. Geological Survey Oil and Gas Investigation Preliminary Map 10.

Rothrock, E. P., and Robinson, T. W., Jr., 1936, Artesian conditions in west-central South Dakota: South Dakota Geological Survey Report of Investigations, no. 26, 93 p.

Russell, W. L., 1928, The origin of artesian pressure: Economic Geology, v. 23, no. 2, p. 132-157.

Schoon, R. A., 1971, Geology and hydrology of the Dakota formation in South Dakota: South Dakota Geological Survey Report of Investigations, no. 104, 55 p.

Schultz, L. G., 1964, Quantitative interpretation of mineralogical composition from $x$-ray and chemical data for the Pierre shale: U.S. Geological Survey Professional Paper 391-C, $31 \mathrm{p}$.

1965, Mineralogy and stratigraphy of the lower part of the Pierre shale, South Dakota and Nebraska: U.S. Geological Survey Professional Paper 392-B, 19 p.

Scott, R. F., 1963, Principles of soil mechanics: Reading, Mass., Addison-Wesley, $550 \mathrm{p}$.

South Dakota Geological Survey, 1964, Mineral and Water Resources of South Dakota: Bulletin, no. 16, 295 p.

Steece, F. V., and Howells, L. W., 1965, Geology and ground water supplies in Sanborn County, South Dakota: South Dakota Geological Survey Bulletin, no. 17, 182 p.

Stephens, J. C., 1967, Geology and hydrology of Clay County, South Dakota: South Dakota Geological Survey Bulletin, no. 19 , pt. 1,86 p.

Swenson, F. A., 1968, New theory of recharge to the artesian basin of the Dakotas: Geological Society of America Bulletin, v. 79, p. 163-182.

Terzaghi, C., 1929, The origin of artesian pressure: Economic Geology, v. 24, no. 1, p. 91-100.

Theis, C. V., 1935, The relation between lowering the piezometric surface and the rate and duration of discharge of a well using groundwater storage: Transactions of the American Geophysical Union v. 16, p. 519-524.

Theis, C. V., Brown, R. H., and Meyer, R. R., 1963, Estimating the transmissibility of aquifers from the specific capacity of wells: U.S. Geological Survey Water-Supply Paper 1536-I, p. I1331-I1341.

Thompson, D. G., 1929, The origin of artesian pressure: Economic Geology, v. 24, no. 7, p. 758-771.

Tourtelot, H. A., 1962, Preliminary investigation of the geologic setting and chemical composition of the Pierre shale, Great Plains Region: U.S. Geological Survey Professional Paper 390, 74 p.

Tourtelot, H. A., and Schultz, L. G., 1961, Core from the Irish Creek well, Ziebach County, South Dakota: U.S. Geological Survey Open-File Report 603, 20 p.

Trescott, P. C., 1975, Documentation of finite-difference model for simulation of three-dimensional ground-water flow: U.S. Geological Survey Open-File Report 75-438, $32 \mathrm{p}$.

Tullis, E. H., Gries, J. P. and Cope, J. H., 1954, Inventory of published and unpublished data on the characteristics of saline surface and ground waters of South Dakota: Final Report to U.S. Department of Interior Saline Water Conversion Program, South Dakota School of Mines and Technology, Engineering and Mining Experiment Station, 149 p.

U.S. Geological Survey, Ground Water Site Inventory: Available from Office of Water Data Coordination, U.S. Geological Survey, Reston, VA 22092. 